\title{
EFEITOS DO ALUMÍNIO SOBRE A FERMENTAÇÃO ALCOÓLICA
}

\author{
DENISE AMARAL DUARTE ARANHA
}

Dissertação apresentada à Escola Superior de Agricultura "Luiz de Queiroz", da Universidade de São Paulo, para obtenção do título de mestre em Ciências. Área de Concentração: Ciência e Tecnologia de Alimentos.

\author{
PIRACICABA \\ Estado de São Paulo-Brasil \\ Janeiro - 2002
}




\title{
EFEITOS DO ALUMÍNIO SOBRE A FERMENTAÇÃO ALCOÓLICA
}

\author{
DENISE AMARAL DUARTE ARANHA \\ Bacharel em Ciências Biológicas
}

Orientador: Prof. Dr. LUIZ CARLOS BASSO

Dissertação apresentada à Escola Superior de Agricultura "Luiz de Queiroz", da Universidade de São Paulo, para obtenção do título de mestre em Ciências. Área de Concentração: Ciência e Tecnologia de Alimentos.

\author{
PIRACICABA \\ Estado de São Paulo - Brasil \\ Janeiro - 2002
}


Dados Internacionais de Catalogação na Publicação (CIP)

DIVISÃO DE BIBLIOTECA E DOCUMENTAÇÃO - ESALQ/USP

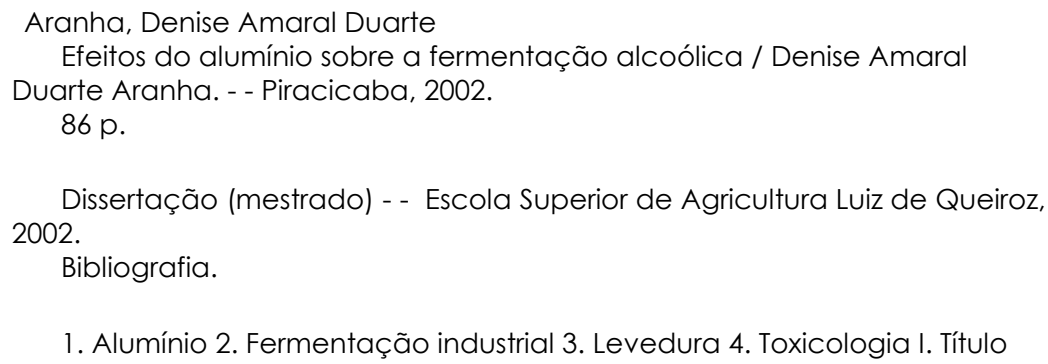

CDD 663.13

\section{"Permitida a cópia total ou parcial deste documento, desde que citada a fonte - $\mathrm{O}$ autor"}


Ao meu marido Léo e à minha filha Larissa

Dedico 
Aos meus pais Roberto e Maria Luiza

Ofereço 


\section{AGRADECIMENTOS}

- Ao Prof.Dr. Luiz Carlos Basso, pela oportunidade, pela orientação neste trabalho e, principalmente, por compartilhar de todo o seu conhecimento e experiência;

- À Fundação de Amparo à Pesquisa do Estado de São Paulo, pela concessão da bolsa de estudos e financiamento do projeto de pesquisa;

- Ao Prof.Dr. Jorge Horii, pelos seus ensinamentos durante o curso;

- À amiga Solange, pelo grande apoio e companheirismo;

- Aos técnicos do Departamento de Bioquímica: Ademir e Luís (Cometa) pela fundamental colaboração na execução dos experimentos;

- À grande amiga Silene, pela convivência, estímulo e, principalmente, pelos incontáveis auxílios prestados;

- À Prof. Sonia Piedade, pela colaboração na análise estatística dos resultados;

- Às estagiárias do Departamento de Bioquímica: Mariana e Juliana, pela colaboração na execução das análises;

- Ao meu marido Leonel pelo incentivo e paciência. 


\section{SUMÁRIO}

Página

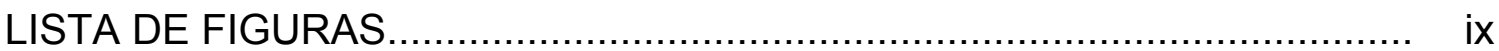

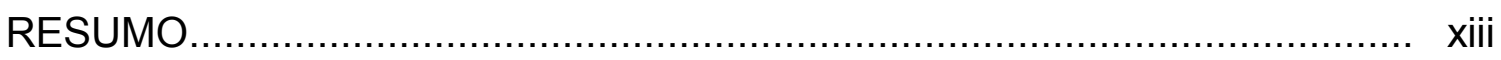

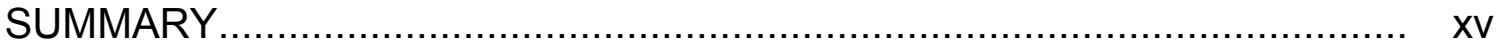

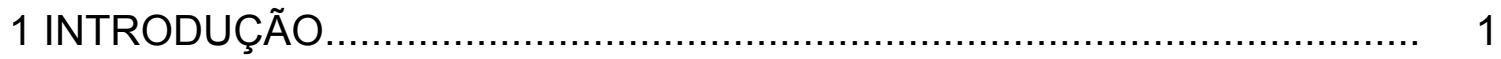

2 REVISÃO DE LITERATURA............................................................. 3

2.1 Alumínio no solo......................................................................... 3

2.2 Toxidez do alumínio..........................................................................

2.2.1 Toxidez do alumínio em leveduras............................................... 5

2.3 Presença do alumínio na fermentação industrial................................... 9

3 MATERIAL E MÉTODOS ............................................................ 11

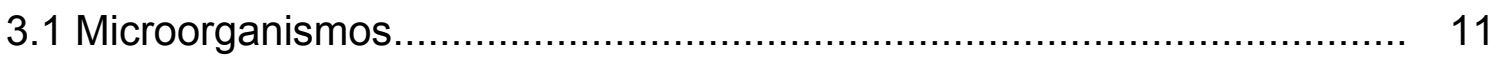

3.2 Multiplicação da levedura.......................................................... 11

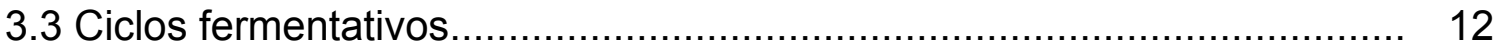

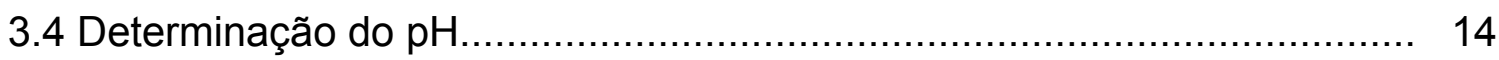

3.5 Determinação de etanol e densidade no vinho...................................... 14

3.6 Determinação de glicerol e açúcares residuais..................................... 14

3.7 Determinação da viabilidade celular e contaminação bacteriana............. 15

3.8 Extração e determinação dos carboidratos de reserva........................... 15

3.9 Determinação de alumínio na levedura.............................................. 15

3.10 Análise estatística....................................................................... 16

4 RESULTADOS E DISCUSSÃO............................................................. 17

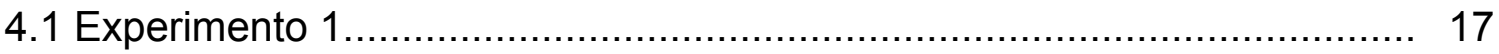


4.1.1 Rendimento em etanol............................................................. 17

4.1.2 Crescimento em biomassa...................................................... 18

4.1.3 Velocidade de fermentação.......................................................... 19

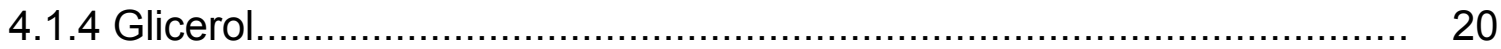

4.1.5 Glicogênio e trealose............................................................ 21

4.1.6 Viabilidade celular................................................................. 22

4.1.7 Contaminação bacteriana....................................................... 23

4.1.8 Acúmulo de alumínio nas células...................................................... 24

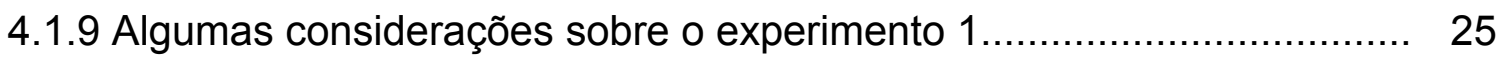

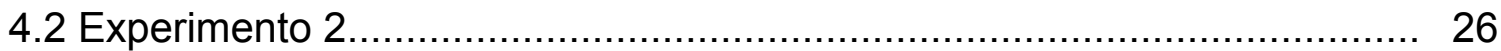

4.2.1 Rendimento em etanol............................................................... 26

4.2.2 Crescimento em biomassa....................................................... 27

4.2.3 Velocidade de fermentação......................................................... 27

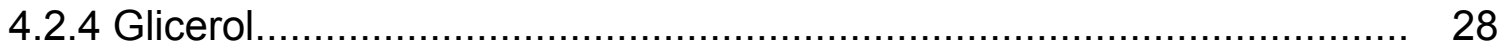

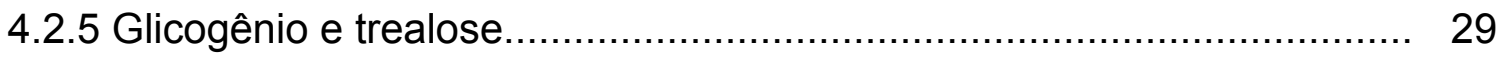

4.2.6 Viabilidade celular .............................................................. 30

4.2.7 Contaminação bacteriana........................................................ 31

4.2.8 Acúmulo de alumínio nas células................................................... 32

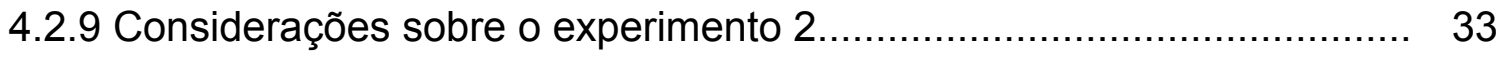

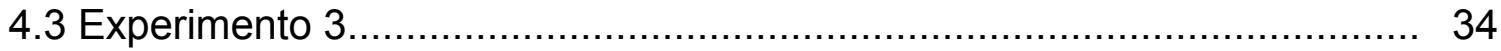

4.3.1 Rendimento em etanol........................................................... 34

4.3.2 Crescimento em biomassa.......................................................... 35

4.3.3 Velocidade da fermentação....................................................... 35

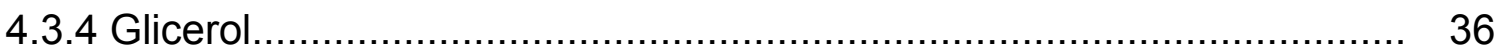

4.3.5 Glicogênio e trealose............................................................. 37

4.3.6 Viabilidade celular .............................................................. 38

4.3.7 Contaminação bacteriana.......................................................... 39

4.3.8 Acúmulo de alumínio nas células.................................................. 40

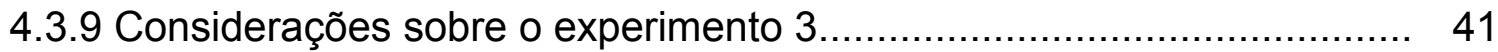

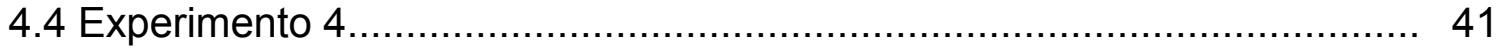


4.4.1 Rendimento em etanol.......................................................... 42

4.4.2 Crescimento em biomassa......................................................... 43

4.4.3 Velocidade da fermentação.......................................................... 44

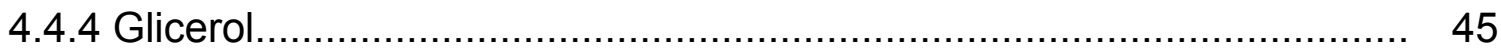

4.4.5 Glicogênio e trealose............................................................ 46

4.4.6 Viabilidade celular.................................................................. 46

4.4.7 Contaminação bacteriana....................................................... 48

4.4.8 Acúmulo de alumínio nas células................................................... 48

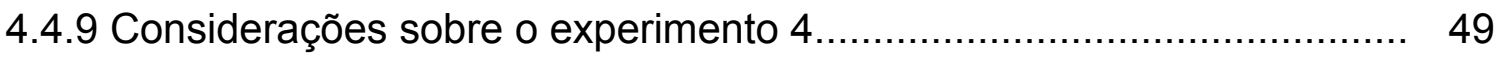

4.5 Considerações gerais sobre a ação do alumínio em fermentação com

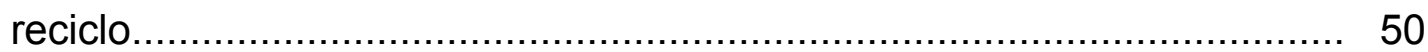

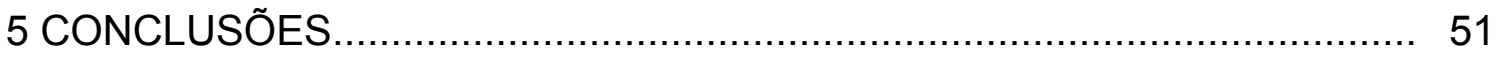

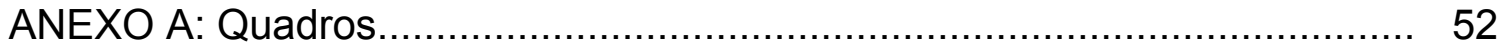

ANEXO B: Análise Estatística.................................................................. 69

REFERÊNCIAS BIBLIOGRÁFICAS..................................................... 80 


\section{LISTA DE FIGURAS}

Página

1 Efeito de diferentes concentrações de alumínio $(0,50$ e $100 \mathrm{mg} / \mathrm{L})$ sobre o rendimento fermentativo (\%), no transcorrer de 6 ciclos fermentativos, empregando-se mosto semi-sintético com $21,73 \%$ de ART e pH 5,0

2 Efeito de diferentes concentrações de alumínio $(0,50$ e $100 \mathrm{mg} / \mathrm{L})$ sobre o crescimento $(\mathrm{g})$ da levedura FLE, no transcorrer de 6 ciclos fermentativos, empregando-se mosto semi-sintético com 21,73 de ART e $\mathrm{pH} 5,0$

3 Efeito de diferentes concentrações de alumínio $(0,50$ e $100 \mathrm{mg} / \mathrm{L})$ sobre a velocidade de fermentação, empregando-se a levedura FLE e mosto semi-sintético com $21,73 \%$ de ART e pH 5,0

4 Efeitos de diferentes concentrações de alumínio (0, 50 e $100 \mathrm{mg} / \mathrm{L})$ sobre a formação de glicerol (g/100g ART) no transcorrer de 6 ciclos fermentativos, empregando-se mosto semi-sintético com 21,73 de ART e pH 5,0. 
5 Efeitos de diferentes concentrações de alumínio (0, 50 e 100 mg/L) sobre a viabilidade da levedura FLE (\%), no transcorrer de 6 ciclos fermentativos, empregando-se mosto semi-sintético com $21,73 \%$ de

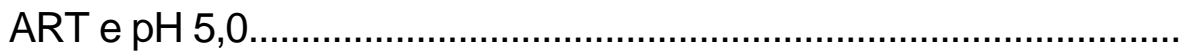

6 Efeito de diferentes concentrações de alumínio (0, 50 e 100 mg/L) sobre o rendimento fermentativo (\%), no transcorrer de 5 ciclos fermentativos, empregando-se a levedura Fleischmann e caldo de cana com 21,90\% de ART (pH 5,0)

7 Efeito de diferentes concentrações de alumínio (0,50 e 100 mg/L) sobre o crescimento (g) da levedura Fleischmann, no transcorrer de 5 ciclos fermentativos, empregando-se a levedura Fleischmann e caldo de

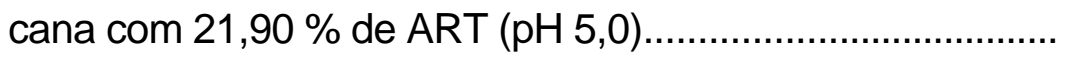

8 Efeito de diferentes concentrações de alumínio (0,50 e 100 mg/L) sobre a velocidade de fermentação ( $\mathrm{g}$ de $\mathrm{CO}_{2}$ ), empregando-se a levedura Fleischmann e caldo de cana com 21,90\% de ART (pH $5,0)$

9 Efeitos de diferentes concentrações de alumínio (0, 50 e 100 mg/L) sobre a formação de glicerol (g/100g ART) no transcorrer de 5 ciclos fermentativos, empregando-se a levedura Fleischmann e caldo de cana com $21,90 \%$ de ART (pH 5,0)

10 Efeitos de diferentes concentrações de alumínio (0, 50 e 100 mg/L) sobre a viabilidade da levedura Fleischmann (\%), no transcorrer de 5 ciclos fermentativos, empregando-se caldo de cana com 21,90 \% de ART (pH 5,0) 
11 Efeito de diferentes concentrações de alumínio (0,50 e $100 \mathrm{mg} / \mathrm{L})$ sobre o rendimento fermentativo (\%), no transcorrer de 5 ciclos fermentativos, empregando-se caldo de cana diluído a 20,20 \% de

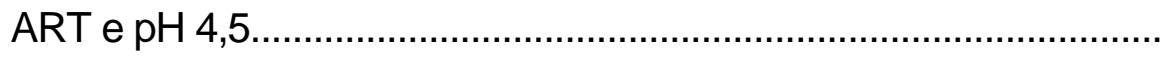

12 Efeito de diferentes concentrações de alumínio $(0,50$ e $100 \mathrm{mg} / \mathrm{L})$ sobre o crescimento $(\mathrm{g})$ da levedura FLE, no transcorrer de 5 ciclos fermentativos, empregando-se caldo diluído a 20,20\% de ART e pH 4,5 .

13 Efeito de diferentes concentrações de alumínio (0, 50 e $100 \mathrm{mg} / \mathrm{L})$ sobre a velocidade de fermentação, empregando-se a levedura FLE e caldo de cana com 20,20 de ART ( $\mathrm{pH} 4,5)$.

14 Efeitos de diferentes concentrações de alumínio $(0,50$ e $100 \mathrm{mg} / \mathrm{L})$ sobre a formação de glicerol ( $\mathrm{g} / 100 \mathrm{~g}$ ART) no transcorrer de 5 ciclos fermentativos, empregando-se caldo de cana diluído a $20,20 \%$ de ART e pH 4,5.

15 Efeitos de diferentes concentrações de alumínio $(0,50$ e $100 \mathrm{mg} / \mathrm{L})$ sobre a viabilidade da levedura FLE (\%), no transcorrer de 5 ciclos fermentativos, empregando-se caldo diluído a $20,20 \%$ de ART e pH 4,5 .

16 Efeito de diferentes concentrações de alumínio (0 e $100 \mathrm{mg} / \mathrm{L}$ ) sobre o rendimento fermentativo (\%), no transcorrer de 5 ciclos fermentativos, empregando-se mosto semi-sintético com 21,87 de ART e pH 4,0, empregando-se as leveduras Fleischmann e PE-2..... 
17 Efeito de diferentes concentrações de Al (0 e $100 \mathrm{mg} / \mathrm{L}$ ) sobre o crescimento (g) das leveduras FLE e PE-2, no transcorrer de 5 ciclos fermentativos, empregando-se mosto semi-sintético com $21,87 \%$ de ART, pH 4,0, empregando-se as leveduras Fleischmann e PE2 .

18 Efeito de diferentes concentrações de alumínio (0 e $100 \mathrm{mg} / \mathrm{L}$ ) sobre a velocidade de fermentação ( $\mathrm{g}$ de $\mathrm{CO}_{2}$ ), empregando-se as leveduras FLE e PE-2 e mosto semi-sintético com $21,87 \%$ de ART, pH 4,0, com as leveduras Fleischmann e PE-2.................................

19 Efeitos de diferentes concentrações de alumínio (0 e $100 \mathrm{mg} / \mathrm{L})$ sobre a formação de glicerol ( $g / 100 \mathrm{~g}$ ART) no transcorrer de 5 ciclos fermentativos, empregando-se mosto semi-sintético com 21,87\% de ART, pH 4,0, com as leveduras Fleiscmann e PE-2........

20 Efeitos de diferentes concentrações de alumínio (0, 50 e $100 \mathrm{mg} / \mathrm{L})$ sobre a viabilidade das leveduras FLE e PE-2 (\%), no transcorrer de 5 ciclos fermentativos, empregando-se mosto semi-sintético com $21,87 \%$ de ART e pH 4,0.............................................................. 


\title{
EFEITOS DO ALUMÍNIO SOBRE A FERMENTAÇÃO ALCOÓLICA
}

\author{
Autora: DENISE AMARAL DUARTE ARANHA \\ Orientador: Prof. Dr. LUIZ CARLOS BASSO
}

\section{RESUMO}

O presente trabalho teve por objetivo estudar distúrbios fisiológicos e bioquímicos causados pelo alumínio em duas linhagens de Saccharomyces cerevisiae: levedura de panificação Fleischmann e a linhagem PE-2. Para tal, procurou-se simular, tanto quanto possível, as condições fisiológicas da fermentação industrial. Foram realizados 4 experimentos, empregando-se mosto semi-sintético e caldo de cana, contendo $200 \mathrm{~g}$ de açúcares redutores totais (ART) por litro. O alumínio foi adicionado na forma de $\mathrm{AlCl}_{3} \cdot 6 \mathrm{H}_{2} \mathrm{O}$ nas seguintes proporções: 0 (testemunha), 50 e $100 \mathrm{mg} / \mathrm{L}$, nos experimentos de $1 \mathrm{a}$ 3 , e 0 e $50 \mathrm{mg} / \mathrm{L}$, no experimento 4, variando-se o pH dos mostos de 4,0 a 5,0. Os experimentos foram conduzidos com reciclo de células, sendo avaliados os seguintes parâmetros: rendimento em etanol, formação de glicerol e açúcares residuais, crescimento em biomassa, viabilidade celular, contaminação bacteriana, teores iniciais e finais dos carboidratos de reserva (trealose e glicogênio) e acúmulo de alumínio nas células de levedura. Concluiu-se que níveis tóxicos de alumínio podem estar presentes em mostos industriais, pois 
os efeitos tóxicos foram constatados em ambas linhagens, porém, a linhagem PE-2 mostrou-se mais resistente a tais efeitos quando comparada com a levedura de panificação Fleischmann. 


\title{
ALUMINUM EFFECTS TOWARD ALCOHOLIC FERMENTATION
}

\author{
Author: DENISE AMARAL DUARTE ARANHA \\ Adviser: Prof. Dr. LUIZ CARLOS BASSO
}

\section{SUMMARY}

The aim of this work was to study physiological and biochemical effects caused by aluminum (Al) in two strains of Saccharomyces cerevisiae: baker's yeast Fleischmann and strain PE-2. For such, was tried to simulate, so much as possible, the physiological conditions of the industrial process. Four experiments were performed: using semi-synthetic and cane juice containing $200 \mathrm{~g}$ of total reducing sugar per liter at $\mathrm{pH} 4.0$ and 5.0. Aluminum was added in the form of $\mathrm{AlCl}_{3} \cdot 6 \mathrm{H}_{2} \mathrm{O}$ in the following proportions: 0 (control), $50 \mathrm{mg} / \mathrm{L}$ and $100 \mathrm{mg} / \mathrm{L}$. The experiments were performed with cell reuse and the following parameters were analysed: ethanol production, glicerol production and residual sugars, growth of the yeast, yeast viability, bacterial contamination, trehalose and glycogen content and accumulation of aluminum in the yeast cells. It was concluded that toxic levels of aluminum could be present in industrial substrates, since toxic effects were verified for both strains. The strain PE-2 showed to be more tolerant to aluminum when compared to baker's yeast. 


\section{INTRODUÇÃO}

A citotoxicidade do alumínio já foi demonstrada em diversos sistemas biológicos, sendo considerada um importante fator limitante da produtividade de muitas culturas, especialmente nos trópicos. Os efeitos tóxicos do alumínio também são observados em bactérias e fungos (Zel et al, 1993).

Segundo Houeland (1990), algumas patologias humanas podem estar associadas com a contaminação por alumínio.

A constatação da presença do alumínio em níveis potencialmente tóxicos em mostos industriais (Basso ,1989; Basso \& Amorim, 1997), leva a crer que, em relação ao processo biotecnológico de produção de etanol combustível conduzido no país, denominado Melle-Boinot (onde as células de levedura são recuperadas por centrifugação e reaproveitadas, impondo àlevedura uma condição fisiológica peculiar, que pode proporcionar o acúmulo do metal), devia-se abordar a possibilidade do alumínio ser um agente comprometedor da eficiência do processo industrial. A avaliação, em condições fisiológicas semelhantes æ̀̀ da indústria, do desempenho da levedura, em função de teores de alumínio no meio, é o primeiro passo para que seja sugerido o controle do metal na atividade industrial.

Este trabalho teve como objetivo verificar disturbios fisiológicos e bioquímicos causados pelo alumínio sobre a levedura e avaliar o comprometimento que possam ocasionar na eficiência do processo 
fermentativo. Procurou-se simular tanto quanto possível, as condições fisiológicas da fermentação industrial.

Foram determinados os parâmetros de rendimento em etanol, formação de glicerol e açúcares residuais, crescimento em biomassa, viabilidade celular, contaminação bacteriana, acúmulo de alumínio nas células e conteúdos celulares de trealose e glicogênio . 


\section{REVISÃO DE LITERATURA}

\subsection{Alumínio no solo}

O alumínio é o metal mais abundante e o terceiro elemento em teor na crosta terrestre, principalmente nas formas insolúveis e atóxicas de aluminosilicatos ou óxidos, mas, àmedida que os solos se tornam mais á cidos, formas fitotóxicas de alumínio são disponibilizadas, nomeadamente o íon $\mathrm{Al}^{3+}$, na forma hexahidratada de $\mathrm{Al}\left(\mathrm{H}_{2} \mathrm{O}\right)_{6}{ }^{3+}$ (Kochian, 1995).

O problema da toxidez por alumínio é particularmrnte sério, em subsolos fortemente ácidos, por dificultar a calagem. Frequentemente, esses solos têm a acidez intensificada pela aplicação pesada de fertilizantes de reação ácida, álem de que, em muitos países tropicais, a alta aplicação de calcário necessária para a correção da acidez pode não constituir alternativa econômica ( Howeler,1991).

Atividades industriais e o uso de fertilizantes têm contribuído para a acidificação de solos e, conseqüentemente, aumentado a quantidade de alumínio solúvel $\left(\mathrm{A}^{3+}\right)$, acarretando problemas em ambientes terrestres e aquáticos anteriormente sem toxidez do elemento em questão (Kochian, 1995). Assim, o declínio de florestas tem sido relacionado com a toxidez do alumínio 
presente nas chuvas ácidas decorrentes da poluição ambiental (Luttge \& Clarkson) ${ }^{1}$, citado por Zel et al (1993).

O metal se faz presente especialmente em solos naturalmente ácidos $(\mathrm{pH}<5,0)$, principalmente das regiões tropicais, podendo compreender até $40 \%$ de toda a área arável do mundo (Kochian, 1995). No entanto, estima-se que, na América tropical, cerca de $70 \%$ dos solos apresentem toxidez por alumínio (Haug \& Vitorello, 1997).

Tipicamente, íons de alumínio são tidos como o maior fator tóxico em solos ácidos. Em soluções ácidas $(\mathrm{pH}<5,0), \mathrm{Al}^{+3}$ existe como um octaedro hexahidratado, $\mathrm{Al}\left(\mathrm{H}_{2} \mathrm{O}\right)_{6}{ }^{3+}$. Quando $0 \mathrm{pH}$ se eleva, sofre sucessivas desprotonações para formar $\mathrm{Al}(\mathrm{OH})^{2+}$ e $\mathrm{Al}(\mathrm{OH})_{2}{ }^{+}$( Kochian, 1995). Entretanto, a maioria dos relatos indicam o cátion trivalente como a espécie mais tóxica æ̀s plantas (Howeler, 1991).

\subsection{Toxidez do alumínio}

A toxidez do alumínio é considerada um importante fator limitante da produtividade de muitas culturas com consequentes reflexos econômicos, razão pela qual, uma considerável quantidade de informações está disponível na literatura sobre os efeitos tóxicos do elemento para as plantas (Haug, 1984).

A toxidez do alumínio também é observada em outros organismos, além

das plantas. Assim, o íon $\mathrm{Al}^{+3}$ é igualmente tóxico para microrganismos, incluindo bactérias, fungos e algas verdes (Foy \& Gerloff, 1972; Date \& Holliday, 1979;

LUTTGE, U.; CLARKSON, D.T. Mineral nutrition: Aluminium. Program Botanical v.53, n.4, p.66-77, 1992. 
Guida et al., 1991; Zel et al., 1993), como também para peixes em ambientes ácidos (Baker \& Schofield, 1982).

O alumínio também foi relacionado a diversos estados patológicos em humanos, incluindo o distúrbio neurológico conhecido como mal de Alzheimer (Houeland, 1990) e síndromes associadas ao tratamento de hemodiálises prolongadas (Arieff, 1990). Portanto, a citotoxicidade do alumínio parece ser um fenômeno bastante generalizado, conforme sugeriram MacDiarmid \& Gardner (1996).

Embora intensivamente estudado pelas mencionadas razões clínicas, econômicas e ecológicas, ainda não existem informações definitivas para sugerir um mecanismo de ação tóxica do íon alumínio nos sistemas biológicos (MacDiarmid \& Gardner, 1996). No entanto o alumínio se mostrou como inibidor das hexoquinases de levedura e de cérebro bovino, fato descoberto de forma acidental, quando se verificou que preparações de ATP empregadas na reação enzimática estavam contaminadas com alumínio (Womack \& Colowick, 1979; Exley et al., 1994). Posteriormente, o íon alumínio comportou-se como inibidor da desidrogenase de glucose-6-fosfato em levedura de panificação (Cho \& Joshi, 1989). A ribonuclease ácida isolada de cérebro bovino foi ativada por baixa concentração de alumínio, ocorrendo um aumento da atividade enzimática de 2 a 3 vezes em presença de $10 \mu \mathrm{M}$ de alumínio, evidenciando-se que o acúmulo de alumínio no cérebro poderia alterar a regulação do metabolismo dos ácidos nucléicos (Cho \& Kim, 1991).

\subsubsection{Toxidez do alumínio em leveduras}


Yoshino et al. (1992) relataram o efeito inibitório "in vitro" do íon alumínio sobre a desidrogenase isocítrica de levedura, tanto NAD como NADP dependentes, e concluíram que tal efeito poderia reduzir a produção aeróbica de energia pela levedura, podendo também contribuir para a toxicidade biológica do alumínio nos ecossistemas e em humanos.

Mais recentemente, Jones \& Kochian (1997) demonstraram a alta afinidade do íon alumínio com o fosfaditilinositol-4,5-bifosfato, componente de membrana envolvido com transdução de sinal. Os autores ainda relataram que $\mathrm{Ca}^{+2}$, citrato e malato previniram tal interação, justificando a já observada atuação destes como atenuadores da toxidez do alumínio. A conclusão principal dos autores foi que o mecanismo de ação tóxica do alumínio se deve àsua ligação com componentes lipídicos específicos da membrana e não conforme a hipótese mais corrente de que o alumínio estaria exercendo o seu efeito tóxico ao se ligar a sítios catalíticos de enzimas dependentes de metal ativador.

Estudos, com a técnica de espectroscopia de ressonância magnética nuclear com o isótopo $\mathrm{Al}^{27}$, demonstraram que o íon alumínio consegue penetrar em células de levedura após 15 minutos de exposição ao metal, atingindo um equilíbrio após 4 horas. $\mathrm{O}$ ácido cítrico bloqueia tal entrada, enquanto o EDTA promove a saída de todo alumínio do interior da célula (Rao \& Easwaran, 1997). Essas descobertas recentes explicam observações anteriores de que a excreção de ácidos orgânicos pelas raízes das plantas confere tolerância ao alumínio (Klimashevsky \& Chernysheva, 1980; Suhayda \& Haug, 1986).

Estudos desenvolvidos na Nova Zelândia proporcionaram grandes avanços no sentido da compreensão da forma de ação do alumínio em microrganismos. Optou-se pela levedura Saccharomyces cerevisiae como organismo-modelo devido ao fato de ela se mostrar sensível ao íon alumínio, crescer em valor de $\mathrm{pH}$ no qual o alumínio se apresenta na forma tóxica de $\mathrm{Al}^{+3}$, de o seu genoma já estar mapeado e da facilidade da condução de ensaios em 
laboratórios. A busca principal de tais pesquisas seria o isolamento de genes que condicionem a tolerância ao alumínio e a sua inserção em plantas de interesse econômico, além de se conhecer os mecanismos de tolerância ao metal (MacDiarmid e Gardner, 1996). Tal grupo, recentemente, relatou que a superexpressão do sistema de transporte de $\mathrm{Mg}^{+2}$ em Saccharomyces cerevisiae confere tolerância ao íon alumínio, e que a toxidez do metal para levedura seria conseqüência de uma redução no influxo de $\mathrm{Mg}^{+2}$ por tal transportador (Schott \& Gardner, 1997; MacDiarmid \& Gardner, 1998). Tais resultados vêm dar embasamento \&̀ observações de que $\mathrm{O} \mathrm{Mg}^{+2}$ alivia a toxidez do alumínio em diversos sistemas biológicos (Jongbloed \& Borstpauwels, 1992).

Ainda recentemente, Yoshino et al. (1998) demonstraram que o íon alumínio causa inibição competitiva da glicerol quinase de levedura de modo competitivo em relação ao substrato Mg-ATP. Os mesmos autores verificaram que $\circ \mathrm{Al}^{+3}$ forma um complexo com o ATP, sendo que a poliamina espermina, em concentrações fisiológicas, promove a remoção do alumínio do complexo, restaurando a atividade enzimática. Os autores sugeriram que, à semelhança do mecanismo de inibição da hexoquinase, o alumínio possa reduzir a utilização da energia química pela levedura. Especularam também, em função dos dados, que alterações nas concentrações das poliaminas poderiam controlar a produção de energia in vivo, respondendo, assim, pela toxicidade do alumínio relacionada com o envelhecimento. Com relação à habilidade do íon alu mínio se complexar com o ATP, Martin (1992) ' 2 , citado por Kochian (1995), afirmou que o complexo de $\mathrm{Al}^{+3}$ com $\mathrm{ATP}^{-4}$ se liga àenzima hexoquinase 1000 vezes mais fortemente em relação ao complexo Mg-ATP e tal característica é proposta como o mecanismo de inibição da enzima pelo alumínio.

Um exame da literatura vem mostrar que as pesquisas envolvendo toxidez do alumínio com leveduras são justificadas principalmente pela facilidade de 
manipulação de um organismo eucariótico simples, sua facilidade de cultivo em laboratório e o fato de o seu genoma já estar mapeado. Percebe-se, pois, que a levedura seria adequada aos estudos fundamentais, buscando as bases moleculares da toxidez do alumínio e que tais dados poderiam ser extrapolados para uma abordagem clínica (toxidez do Al em humanos) ou para os problemas relacionados com fitotoxicidade. Curiosamente se constata que, embora a levedura seja o microrganismo mais amplamente utilizado em processos biotecnológicos como panificação, vinho, cerveja, destilados em geral, produção de biomassa e etanol combustível, poucos trabalhos foram publicados em relação à toxidez do alumínio para leveduras em condições fisiológicas de um processo industrial. Assim, a totalidade das pesquisas mencionadas não está comprometida com qualquer processo biotecnológico e, muito embora tais resultados forneçam os alicerces teóricos para se interpretar a toxidez do alumínio, não se deve descuidar das diferentes condições fisiológicas impostas à levedura.

Uma das raras publicações envolvendo um processo tecnológico, no caso a produção de cerveja, inclusive classifica o alumínio como elemento não tóxico para a levedura (White, 1954). Tal pesquisa foi conduzida para descobrir quais as ligas metálicas que seriam mais apropriadas para a fabricação dos tanques e tubulações da indústria cervejeira, que se modernizava na ocasião, substituindo os obsoletos equipamentos de madeira. Assim, avaliaram-se mais de 40 elementos em meio sintético, que foram classificados pela "capacidade de envenenamento". Cd (0,12mg/L), Cu (0,17 mg/L), Ag (0,22 mg/L), Os $(0,72 \mathrm{mg} / \mathrm{L})$, $\mathrm{Hg}(1,55 \mathrm{mg} / \mathrm{L})$ e $\mathrm{Pd}(2,70 \mathrm{mg} / \mathrm{L})$ foram capazes de reduzir o crescimento, sendo considerados os mais tóxicos, enquanto que o alumínio causou o mesmo efeito com doses superiores a $500 \mathrm{mg}$ de $\mathrm{Al}^{+3} / \mathrm{L}$ de meio. Essa pesquisa, que se tornou clássica na literatura sobre nutrição mineral de leveduras, possivelmente tenha

${ }^{2}$ MARTIN, R.B. Aluminum speciation in biology. IN: CHADWICK, D.J.; WHEALAN, J. (Ed.) 
levado os pesquisadores envolvidos com processos biotecnológicos a não creditar importância àtoxidez do alumínio em relação à leveduras, especialmente Saccharomyces cerevisiae. Tanto assim que a literatura registra apenas as pesquisas de Rybarova \& Adamek (1975) relatando efeitos tóxicos do alumínio na faixa de 54 a $108 \mathrm{mg}$ de Al/L na água a ser utilizada no crescimento de Candida utilis para a produção de biomassa. Sugeriram ainda os autores que o possível sítio de atuação do alumínio fosse a membrana plasmática.

\subsection{Presença do alumínio na fermentação industrial}

Foi demonstrado que mostos industriais empregados em várias destilarias na produção de etanol combustível, no Estado de São Paulo, podem apresentar teores de alumínio normalmente oscilando entre 8 e $40 \mathrm{mg} / \mathrm{L}$, mas podendo chegar a $130 \mathrm{mg} / \mathrm{L}$, quando, geralmente, são associados com queda de viabilidade celular da levedura do processo industrial. Tal constatação não pode ainda ser creditada unicamente ao alumínio, devido à falta de controle de outros parâmetros da fermentação industrial. No entanto, em ensaios de laboratório, doses de $10 \mathrm{mg}$ de $\mathrm{Al} / \mathrm{L}$ de meio semi-sintético já exercem efeito depressivo sobre o crescimento e a viabilidade celular, mas, ao se empregar meios de melaço, tais efeitos tóxicos são atenuados, possivelmente devido a agentes complexantes presentes no meio (Basso et al., 1989; Basso \& Amorim, 1997). Os resultados alcançados demonstram ser viáveis estudos mais aprofundados sobre a toxicidade do alumínio para a levedura no processo industrial.

Aluminum in Biology and Medicine. New York: Wiley, 1992. p.5-25. 
De qualquer forma, como a cana-de-açúcar também é cultivada em solos ácidos com grande disponibilidade de alumínio, é de se esperar que o caldo utilizado no preparo dos mostos contenha o mencionado elemento. Tanto assim, que análises conduzidas pelo Centro Tecnológico da Copersucar, referentes à safra 97/98, têm mostrado teores médios de $156 \mathrm{mg} \mathrm{Al} / \mathrm{L}$ de caldo destinado à fe rmentação, conforme Silva Jr., $2000{ }^{3}$. Outra possibilidade de adições de alumínio ao meio fermentativo seria em decorrência do emprego de água tratada com alúmen de potássio ou sulfato de alumínio, prática essa utilizada em muitas unidades industriais.

Outro interessante aspecto a se considerar é que no processo industrial de produção de etanol a levedura é reutilizada de um ciclo fermentativo para outro, em fermentações de 6-10 horas, perfazendo-se facilmente dois ciclos fermentativos por dia, no transcorrer de uma safra que se estende por 200 a 250 dias. Esse intenso reciclo da levedura, característica peculiar do processo industrial instalado no país, poderia levar a um efeito acumulativo do alumínio, acarretando efeitos tóxicos do metal mesmo para níveis mais baixos do que aqueles preconizados na literatura.

\footnotetext{
${ }^{3}$ SILVA JUNIOR. Comunicação pessoal, 2000.
} 


\section{MATERIAL E MÉTODOS}

\subsection{Microrganismos}

As leveduras Sacharomyces cerevisiae, linhagens PE-2 e Fleischmann de panificação, foram obtidas da coleção do Setor de Bioquimica do Departamento de Ciências Biológicas, da ESALQ/USP em Piracicaba S.P., onde são mantidas liofilizadas. Essas leveduras foram inoculadas em $100 \mathrm{ml}$ de meio YEPD (extrato de levedura 1,0\%, peptona bacteriológica 1,0\% e dextrose 2,0\%), com pH 6,57,0 e incubadas por $48 \mathrm{~h}$ a $32^{\circ} \mathrm{C}$.

\subsection{Multiplicação da levedura}

Nos quatro experimentos realizados fez-se o mesmo procedimento de multiplicação das leveduras, sendo as suspensões tranferidas para frascos erlenmeyer contendo $1.5 \mathrm{~L}$ de meio da crescimento, esterilizado, com $6 \%$ de ART (açúcares redutores totais) e suplementado com $\mathrm{K}_{2} \mathrm{HPO}_{4}(0,87 \mathrm{~g} / \mathrm{L}),\left(\mathrm{NH}_{4}\right)_{2} \mathrm{SO}_{4}$ $(0,66 \mathrm{~g} / \mathrm{L})$, uréia $(0,30 \mathrm{~g} / \mathrm{L}), \mathrm{MgSO}_{4} .7 \mathrm{H}_{2} \mathrm{O} \quad(0,49 \mathrm{~g} / \mathrm{L}), \quad \mathrm{ZnSO}_{4} .7 \mathrm{H}_{2} \mathrm{O} \quad(30 \mathrm{mg} / \mathrm{L})$, $\mathrm{MnSO}_{4} \mathrm{H}_{2} \mathrm{O}(20 \mathrm{mg} / \mathrm{L})$ e ácido linolêico (30mg/L, conforme Alves (1994), onde permaneceram por aproximadamente $24 \mathrm{~h} \mathrm{a} 30^{\circ} \mathrm{C}$. Cessada a 
fermentação, após aproximadamente 24 horas, acrescentou-se mais 2 litros do meio de crescimento, mantendo-se a temperatura ambiente, finalizando-se o crescimento com mais adição de meio, obtendo-se assim, $5 \mathrm{~L}$ de suspensão. Cessado o crescimento, após 24 horas, as suspensões foram armazenadas em câmara fria, a $4^{\circ} \mathrm{C}$, para a decantação da levedura. Após remoção do meio sobrenadante, obteve-se uma suspensão mais concentrada da qual se originou, por centrifugação a 800 xg por 20 min., a massa de levedura necessária para os experimentos.

\subsection{Ciclos fermentativos}

Os experimentos 1 e 4 foram realizados empregando-se mosto semisintético composto de extrato de levedura $(2,50 \mathrm{~g} / \mathrm{L})$, citrato biamônio $(2,26 \mathrm{~g} / \mathrm{L})$, $\mathrm{K}_{2} \mathrm{HPO}_{4} \cdot 3 \mathrm{H}_{2} \mathrm{O} \quad(1,14 \mathrm{~g} / \mathrm{L}), \quad \mathrm{MgSO}_{4} \cdot 7 \mathrm{H}_{2} \mathrm{O}(0,24 \mathrm{~g} / \mathrm{L}), \quad \mathrm{ZnSO}_{4} \cdot 7 \mathrm{H}_{2} \mathrm{O} \quad(29 \mathrm{mg} / \mathrm{L})$ e $\mathrm{MnSO}_{4} \cdot \mathrm{H}_{2} \mathrm{O}(17 \mathrm{mg} / \mathrm{L})$, com $200 \mathrm{~g} \mathrm{ART/L}$ (obtido de sacarose). Nos experimentos 2 e 3 empregou-se caldo de cana diluído também para o teor de $200 \mathrm{~g}$ ART/L.

Para os três primeiros experimentos empregou-se a levedura Fleischmann de panificação e foram preparados 5 litros de mosto, repartindo-se em 3 porções, ஷ̀ quais foram acrescidas de alumínio na forma de $\mathrm{AlCl}_{3} \cdot 6 \mathrm{H}_{2} \mathrm{O}$, resultando em concentrações de 0,50 e $100 \mathrm{mg}$ de $\mathrm{Al} / \mathrm{L}$ de mosto. Ajustou-se, em seguida, $\mathrm{O}$ $\mathrm{pH}$ com $\mathrm{HCl}$ (experimentos 1 e 2: $\mathrm{pH}$ 5,0, e experimento 3: $\mathrm{pH} 4,5$ ) e então os meios foram autoclavados em frascos erlenmeyer e a seguir os meios foram distribuidos em porções de $200 \mathrm{ml}$ e congelados (porções utilizadas em cada reciclo), para então serem utilizados nos ciclos fermentativos. 
Para o experimento 4 foram preparados 4 litros de mosto, repartindo-se em 2 porções, æ̀ quais foram acrescidas de $\mathrm{AlCl}_{3} \cdot 6 \mathrm{H}_{2} \mathrm{O}$ para resultar em 0 e 100 $\mathrm{mg} \mathrm{Al} / \mathrm{L}$.Em ambos os experimentos o $\mathrm{pH}$ foi ajustado para $4,0 \mathrm{com} \mathrm{HCl}$. Os procedimentos finais de preparo do mosto foram seguidos como o descrito anteriormente. Nestes dois experimentos foi realizado um estudo comparativo entre as leveduras Fleischmann de panificação e a linhagem PE-2 frente ao alumínio.

As fermentações foram conduzidas em tubos de centrífuga de $150 \mathrm{ml}$ de capacidade, contendo $7 \mathrm{~g}$ (massa úmida centrifugada) de levedura suspensa em $20 \mathrm{ml}$ de água destilada esterilizada, acidulada a $\mathrm{pH}=2,0 \mathrm{com} \mathrm{H}_{2} \mathrm{SO}_{4}$ e mantida em repouso por $1 \mathrm{~h}$, sendo após adicionados $60 \mathrm{~m}$ do respectivo mosto. Os experimentos foram conduzidos com 4 repetições para cada tratamento (nos três primeiros experimentos) e com 3 repetições no experimento 4.

A velocidade de fermentação foi avaliada pela perda de peso $\left(\mathrm{CO}_{2}\right)$ a cada hora, e, após o seu término, os tubos foram centrifugados ( $800 \mathrm{xg}$ por 15 minutos), sendo a massa de levedura pesada e reutilizada num ciclo fermentativo subsequente, precedida do tratamento com ácido sulfúrico. No vinho delevedurado, foram estimados os teores de glicerol e açúcares residuais (pela técnica da cromatografia líquida de alta eficiência), teor de álcool e valor de $\mathrm{pH}$, segundo preconizado por ZAGO et al, 1989.

\subsection{Determinação do pH}

O valor de $\mathrm{pH}$ foi determinado através de um potenciômetro digital modelo 601- Orion Research. 


\subsection{Determinação de etanol e densidade no vinho}

O etanol foi determinado mediante destilação através de um microdestilador Kjeldhal e leitura do grau alcoólico em um densímetro digital (Anton-Paar DMA-48).

\subsection{Determinação de glicerol e açúcares residuais}

Nos vinhos delevurados, foram estimados os teores de glicerol e açúcares residuais pela técnica de cromatografia líquida de alta eficiência, empregando-se o cromatógrafo Dionex-DX-300, equipado com coluna Carbopac-1 e NaOH 100 $\mathrm{mM}$ como eluente e detetor de amperometria de pulso com eletrodo de ouro.

\subsection{Determinação da viabilidade celular e contaminação bacteriana}

A viabilidade celular foi determinada no vinho bruto por contagem com corante de eritrosina, segundo Amorim et al (1989), via microscópio ótico com objetiva de imersão (100x), através de câmara de Neubauer e a quantidade de bactérias vivas presentes, mediante coloração diferencial com azul de metileno e observação ao microscópio ótico. 


\subsection{Extração e determinação dos carboidratos de reserva}

Foram estimados os teores de trealose e glicogênio nas leveduras, no início do ensaio e ao final do último ciclo fermentativo.

A trealose foi extraída com ácido tricloroacético $-\mathrm{CCl}_{3} \mathrm{COOH} 0,5 \mathrm{M}$ (TCA) em banho de gelo segundo Trevelyan \& Harrison (1956), seguida de reação colorimétrica com antrona em meio sulfúrico, de acordo com o procedimento descrito por Brin (1966). O glicogênio foi determinado mediante extração alcalina com $\mathrm{Na}_{2} \mathrm{CO}_{3}$, hidrólise com amiloglicosidase e dosagem enzimática da glicose com o sistema glicose-oxidase peroxidase (Costa - Carvalho et al, 1986).

\subsection{Determinação de alumínio na levedura}

A determinação de alumínio foi realizada nos mostos empregados $(0, \mathrm{e}$ $100 \mathrm{mg} / \mathrm{L}$ ) e nas leveduras do início, terceiros e últimos ciclos fermentativos, através de digestão nitroperclórica segundo Sarruge e Haag (1974) e posterior emprego do método Xilenol - Orange. Este procedimento é uma readaptação do método espectrofotométrico de determinação de alumínio em solos, desenvolvido por Pritchard (1967) e adaptado por Zago et. al. (1989). 


\subsection{Análise estatística}

Os dados foram estatisticamente analisados segundo parcelas subdivididas, tendo os teores de alumínio como tratamentos e os ciclos fermentativos como parcelas.

Utilizou-se o programa estatístico SAS e a comparação das médias foi feita através do teste de Tukey.

Os resultados da análise estatística podem ser observados no Anexo 2. 


\section{RESULTADOS E DISCUSSÃO}

\subsection{Experimento 1 (mosto semi-sintético, pH 5,0, com 0, 50 e $100 \mathrm{mg} \mathrm{Al/L)}$}

Optou-se por apresentar os dados por experimentos pelo fato de terem sido empregadas situações particulares em cada um deles.

Os quadros que geraram os gráficos encontram-se no Anexo A.

\subsubsection{Rendimento em etanol}

No experimento 1, no qual se empregou mosto semi-sintético $(\mathrm{pH} 5,0)$, houve aumento no rendimento em etanol especialmente na dose de $100 \mathrm{mg} / \mathrm{L}$ (Figura 1). Este resultado está de acordo com o obtido por Basso (1990), que trabalhou com a levedura Fleischmann, empregando-se doses de 10, 50 e 100 $\mathrm{mg} \mathrm{Al} / \mathrm{L}$ em meio semi sintético. 


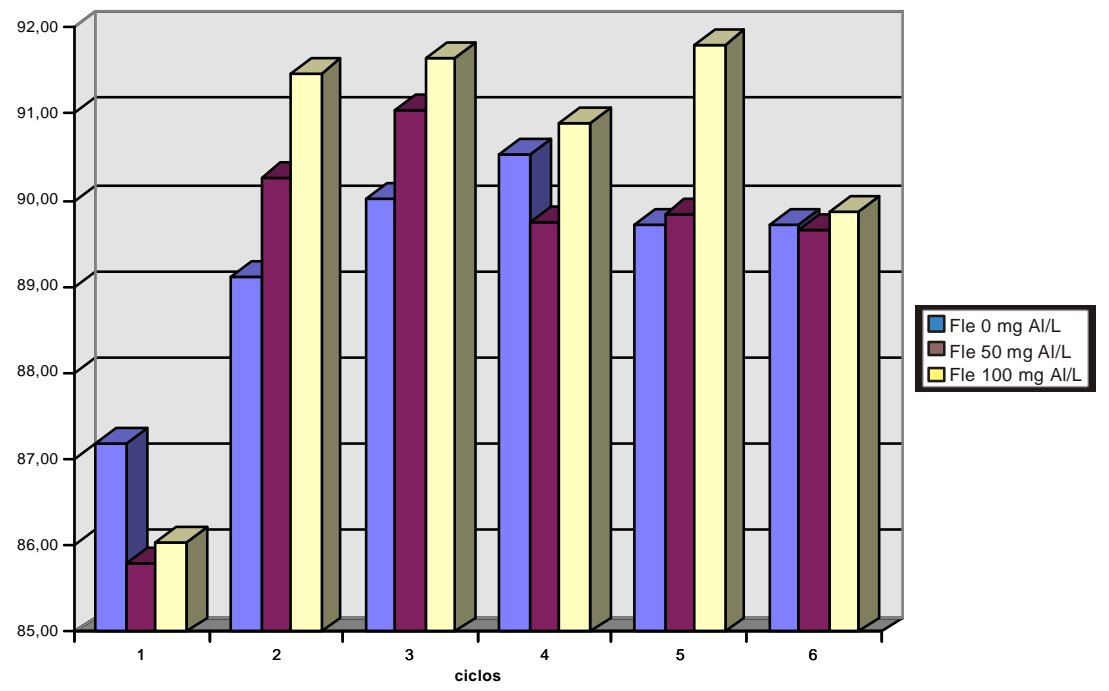

Figura 1 - Efeito de diferentes concentrações de alumínio (0, 50 e 100 mg/L) sobre o rendimento fermentativo (\%), no transcorrer de 6 ciclos fermentativos, empregando-se mosto semi-sintético com 21,73\% de ART e pH 5,0.

\subsubsection{Crescimento em biomassa}

O experimento 1 mostrou menor crescimento em biomassa nos tratamentos com 50 e $100 \mathrm{mg} \mathrm{Al/L}$ (Figura 2), podendo haver relação com a inibição causada pelo íon $\mathrm{Al}^{+3}$, em etapas da glicólise, observada por alguns autores. Assim Cho \& Joshi (1989) verificaram o alumínio como inibidor da desidrogenase de glicose-6-fosfato em levedura de panificação, enquanto Yoshino et al (1992), mostraram o efeito inibitório do íon $\mathrm{Al}^{+3}$ sobre a desidrogenase isocítrica da levedura, sugerindo que tal efeito poderia reduzir a produção aeróbica de energia pela levedura. Embora o processo seja anaeróbico, parte do ciclo de Krebs é operante, colaborando para a produção de esqueletos carbônicos para processos biossintéticos. 


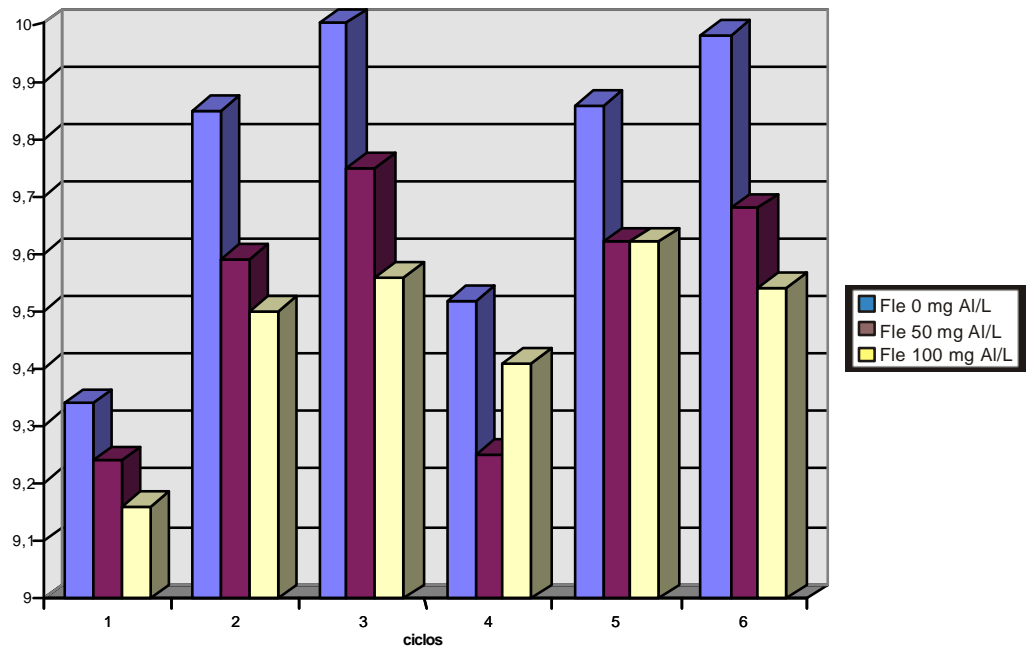

Figura 2 - Efeito de diferentes concentrações de alumínio (0, 50 e $100 \mathrm{mg} / \mathrm{L})$ sobre o crescimento $(\mathrm{g})$ da levedura FLE, no transcorrer de 6 ciclos fermentativos, empregando-se mosto semi-sintético com 21,73 de ART e pH 5,0.

\subsubsection{Velocidade de fermentação}

Neste experimento a presença do alumínio acarretou redução na velocidade de fermentação até 7 horas.

Os resultados referentes à velocidade de fermentação estão de acordo com aqueles obtidos por Basso (1990), onde era notória tal redução quando da presença do alumínio no mosto, já na dose $10 \mathrm{mg} \mathrm{Al} / \mathrm{L}$. A redução na velocidade de fermentação foi tanto maior, quanto maior o teor de alumínio no mosto. 
VELOCIDADE DE FERMENTAÇÃO ( $\mathrm{g}$ CO2)

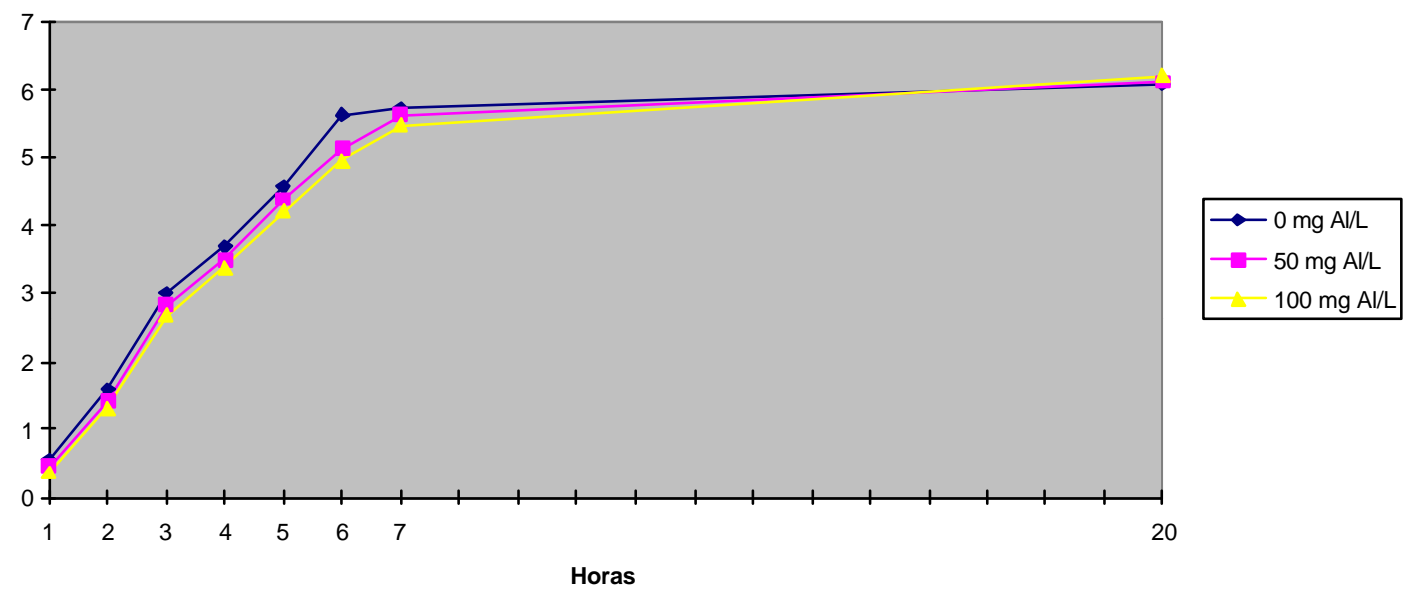

Figura 3 - Efeito de diferentes concentrações de alumínio (0, 50 e $100 \mathrm{mg} / \mathrm{L})$ sobre a velocidade de fermentação, empregando-se a levedura FLE e mosto semisintético com $21,73 \%$ de ART e pH 5,0.

\subsubsection{Glicerol}

O experimento 1 não mostrou alteração estatisticamente significativa na formação de glicerol ( Figura 4), embora se perceba uma tendência de maior formação de glicerol, conforme já documentado (Basso, 1990). Assim, com exceção do terceiro ciclo fermentativo, se nota pequena alteração nos teores de glicerol, especialmente na dose de $100 \mathrm{mg} \mathrm{Al} / \mathrm{L}$. 


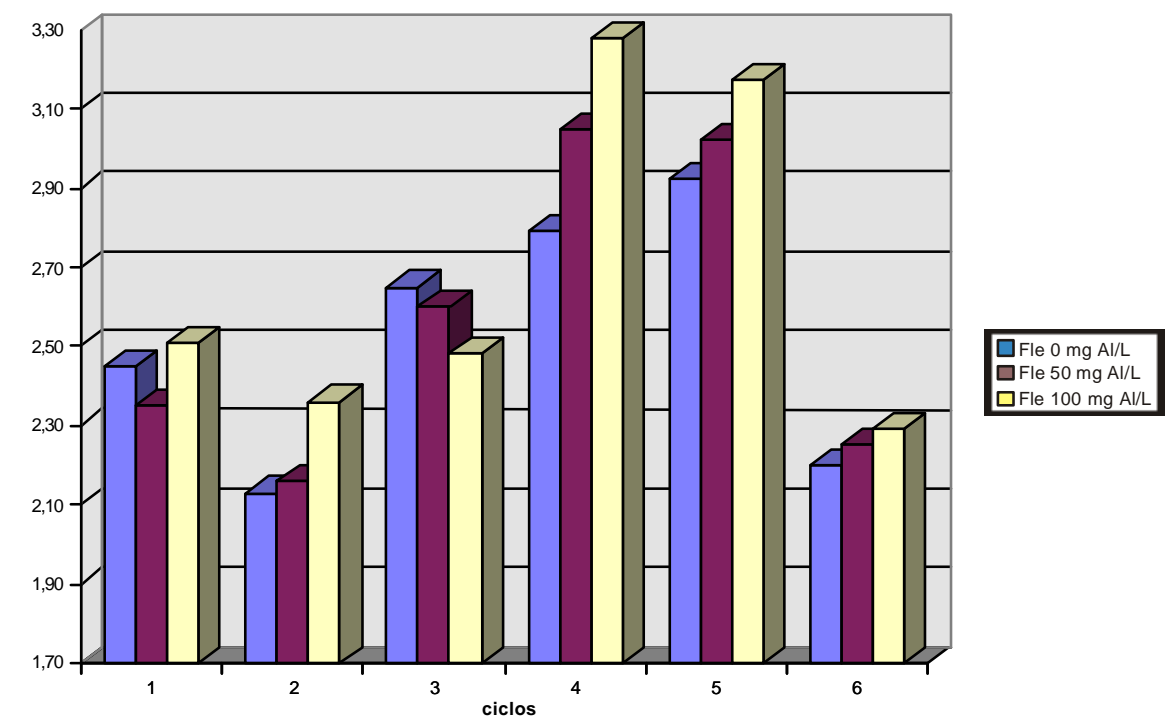

Figura 4 - Efeitos de diferentes concentrações de alumínio (0, 50 e 100 mg/L) sobre a formação de glicerol (g/100g ART) no transcorrer de 6 ciclos fermentativos, empregando-se mosto semi-sintético com 21,73 de ART e pH 5,0.

\subsubsection{Glicogênio e trealose}

Os teores de glicogênio e trealose igualmente não apresentaram diferenças significativas pela análise estatística, embora se perceba discreta redução nos níveis de trealose quando da presença do alumínio nos mostos (Quadro 1). A trealose parece responder mais prontamente aos estresses impostos àlevedura, exercendo uma ação protetora para a levedura. 


\begin{tabular}{|c|c|c|c|c|}
\hline TRATAMENTOS & \multicolumn{2}{|c|}{ TREALOSE } & \multicolumn{2}{|c|}{ GLICOGÊNIO } \\
\cline { 2 - 5 } Al(mg/L) & \multicolumn{4}{|c|}{$\%$} \\
\hline \multirow{2}{*}{ FLE } & INIC. & FIN. & INIC. & FIN. \\
\cline { 2 - 5 } $\mathbf{0}$ & 0,91 & 2,12 & 7,03 & 9,79 \\
\hline $\begin{array}{c}\text { FLE } \\
\mathbf{5 0}\end{array}$ & 0,91 & 1,75 & 7,03 & 7,54 \\
\hline $\begin{array}{c}\text { FLE } \\
\mathbf{1 0 0}\end{array}$ & 0,91 & 1,65 & 7,03 & 10,08 \\
\hline
\end{tabular}

Quadro 1 - Efeitos de diferentes concentrações de alumínio (0, 50 e $100 \mathrm{mg} / \mathrm{L})$ sobre os teores de trealose (\% na matéria seca) e glicogênio (\%), nos fermentos do início do ensaio e do final do último ciclo, empregando-se mosto semisintético com 21,73\% de ART e pH 5,0.

\subsubsection{Viabilidade celular}

Houve queda de viabilidade da levedura submetida aos reciclos fermentativos (Figura 5), porém sem diferenças quanto à presença de alumínio nos mostos. 


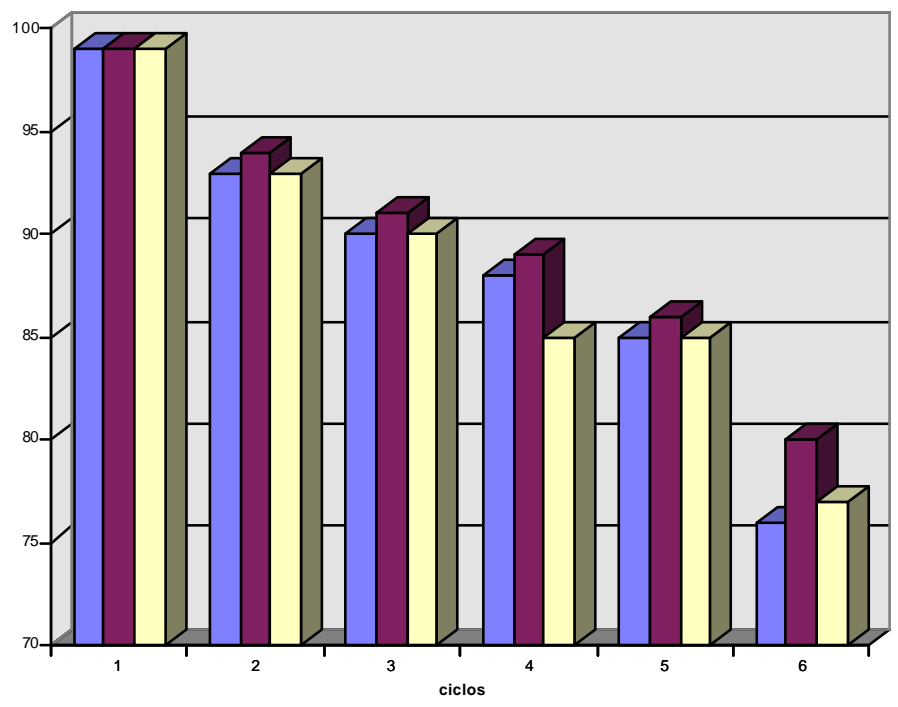

Figura 5 - Efeitos de diferentes concentrações de alumínio (0, 50 e 100 mg/L) sobre a viabilidade da levedura FLE (\%), no transcorrer de 6 ciclos fermentativos, empregando-se mosto semi-sintético com $21,73 \%$ de ART e pH 5,0.

\subsubsection{Contaminação bacteriana}

A presença do alumínio na fermentação não interferiu nesse parâmetro (Quadro 2).

Basso (1991) obteve resultados que evidenciaram redução do número de bactérias contaminantes na presença do metal, mostrando que o alumínio pode exercer efeito tóxico inclusive para as bactérias que podem vir a contaminar o meio de cultura. 


\begin{tabular}{|c|c|c|c|c|c|c|c|}
\hline $\begin{array}{c}\text { TRTAMENTOS } \\
\text { Al (mg/L) }\end{array}$ & \multicolumn{7}{|c|}{$\begin{array}{c}\text { BACTÉRIAS } \\
(\mathrm{ces} / \mathrm{ml} \times 10>6)\end{array}$} \\
\hline \multirow{2}{*}{$\begin{array}{c}\text { FLE } \\
0\end{array}$} & $\mathrm{Bci}$ & $\mathrm{Bc1}$ & $\mathrm{Bc2}$ & $\mathrm{Bc3}$ & $\mathrm{Bc} 4$ & $\mathrm{Bc5}$ & $\mathrm{Bc6}$ \\
\cline { 2 - 8 } & $<0,10$ & $<0,10$ & $<0,10$ & $<0,10$ & $<0,10$ & $<0,10$ & 0,17 \\
\hline $\mathrm{FLE}$ & & & & & & & \\
\hline 50 & $<0,10$ & 0,17 & $<0,10$ & 0,17 & $<0,10$ & $<0,10$ & 0,26 \\
\hline $\mathrm{FLE}$ & & & & & & & \\
100 & $<0,10$ & $<0,10$ & $<0,10$ & $<0,10$ & $<0,10$ & $<0,10$ & $<0,10$ \\
\hline
\end{tabular}

Quadro 2 - Efeitos de diferentes concentrações de alumínio (0, 50 e $100 \mathrm{mg} / \mathrm{L}$ ) sobre a contaminação bacteriana (cels/ml $\times 10^{6}$ ), no transcorrer de 6 ciclos fermentativos, empregando-se mosto semi-sintético com $21,73 \%$ de ART e pH 5,0.

\subsubsection{Acúmulo de alumínio nas células}

No experimento 1 foi notado o acúmulo de alumínio na levedura, sendo favorecido tanto pela dose como pela exposição, ou seja, pelos reciclos fermentativos (Quadro 3).

A análise realizada no mosto testemunha resultou em $5 \mathrm{mg} \mathrm{Al} / \mathrm{L}$. 


\begin{tabular}{|c|r|r|r|}
\hline TRATAMENTO & \multicolumn{3}{|c|}{ mgAl/Kg M.S. } \\
\cline { 2 - 4 } Al mg/L & INICIAL & 3o ciclo & 60 ciclo \\
\hline FLE 0 & 640 & 810 & 1.000 \\
\hline FLE 50 & 640 & 820 & 1.680 \\
\hline FLE 100 & 640 & 1.090 & 2.750 \\
\hline
\end{tabular}

Quadro 3 - Efeitos de diferentes concentrações de alumínio (0, 50 e 100mg/L) sobre o acúmulo do metal nas células, no transcorrer de 6 ciclos fermentativos, empregando-se mosto semi-sintético com 21,73 \% de ART e pH 5,0.

\subsubsection{Algumas considerações sobre o experimento 1}

De uma maneira geral a toxidez do alumínio foi pouco perceptível neste experimento causando pequenos incrementos nas formações de etanol e de glicerol, simultaneamente com reduções na formação de biomassa e da velocidade de fermentação. Pelos dados de viabilidade celular e conteúdos dos carboidratos de reserva (trealose e glicogênio), se deduz que no presente experimento a presença de alumínio no mosto causou discreto efeito tóxico æ̀s leveduras, embora tenha sido constatado um acúmulo progressivo do alumínio nas células. A ausência dos efeitos tóxicos esperados pode ser atribuida aos valores de $\mathrm{pH}$ relativamente alto $(5,0)$ dos mostos, visto que em $\mathrm{pH}$ acima de 4,0 o íon $\mathrm{Al}^{+3}$ (forma tóxica do alumínio) já poderia estar convertido na forma de hidroxido $\left(\mathrm{AL}(\mathrm{OH})_{3}\right)$, não tóxico. Por outro lado, a presença do citrato no meio semi-sintético, igualmente poderia estar complexando o $\mathrm{Al}^{+3}$ e reduzindo a sua ação tóxica, enquanto o magnésio (igualmente presente nos mostos) promovendo 
a superexpressão do sistema de seu próprio transporte e aliviando a toxidez do alumínio em Saccharomyces cerevisiae (Macdiarmid \& Gardner, 1996).

\subsection{Experimento 2}

Utilizou-se mosto de caldo, pH 5,0, com 0, 50 e $100 \mathrm{mg} \mathrm{Al} / \mathrm{L}$, empregandose a levedura Fleischmann.

\subsubsection{Rendimento em etanol}

Observou-se um aumento no rendimento em etanol, principalmente na dose de $100 \mathrm{mg} \mathrm{Al} / \mathrm{L}$ com exceção de $3^{\circ}$ ciclo fermentativo (Figura 6).

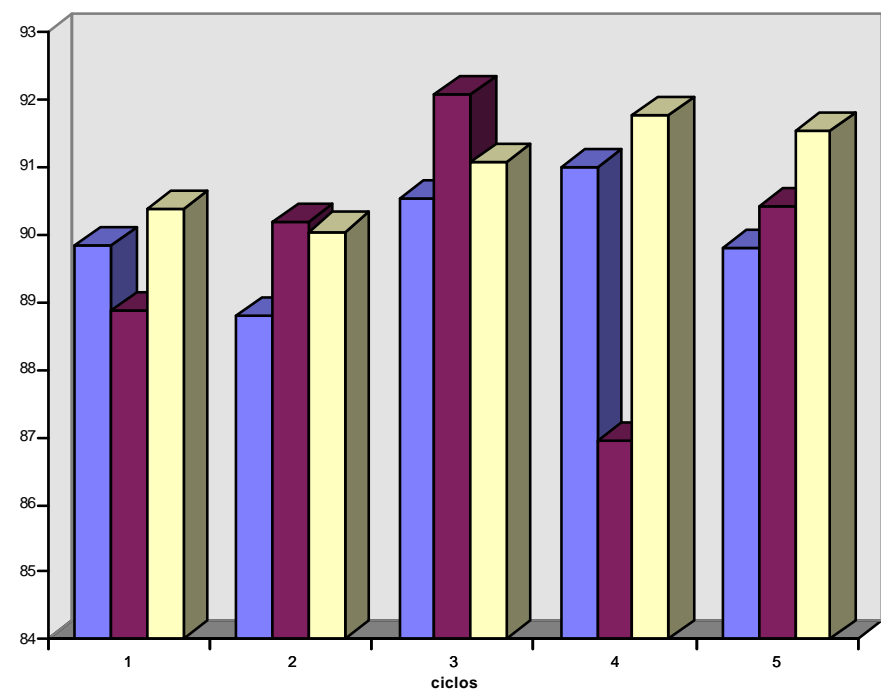

Figura 6 - Efeito de diferentes concentrações de alumínio (0, 50 e $100 \mathrm{mg} / \mathrm{L})$ sobre o rendimento fermentativo (\%), no transcorrer de 5 ciclos fermentativos, empregando-se a levedura Fleischmann e caldo de cana com $21,90 \%$ de ART (pH 5,0). 


\subsubsection{Crescimento em biomassa}

Embora tenha ocorrido um incremento na biomassa de levedura no transcorrer do experimento, a presença do alumínio nas doses estudadas não afetou a formação de biomassa (Figura 7).

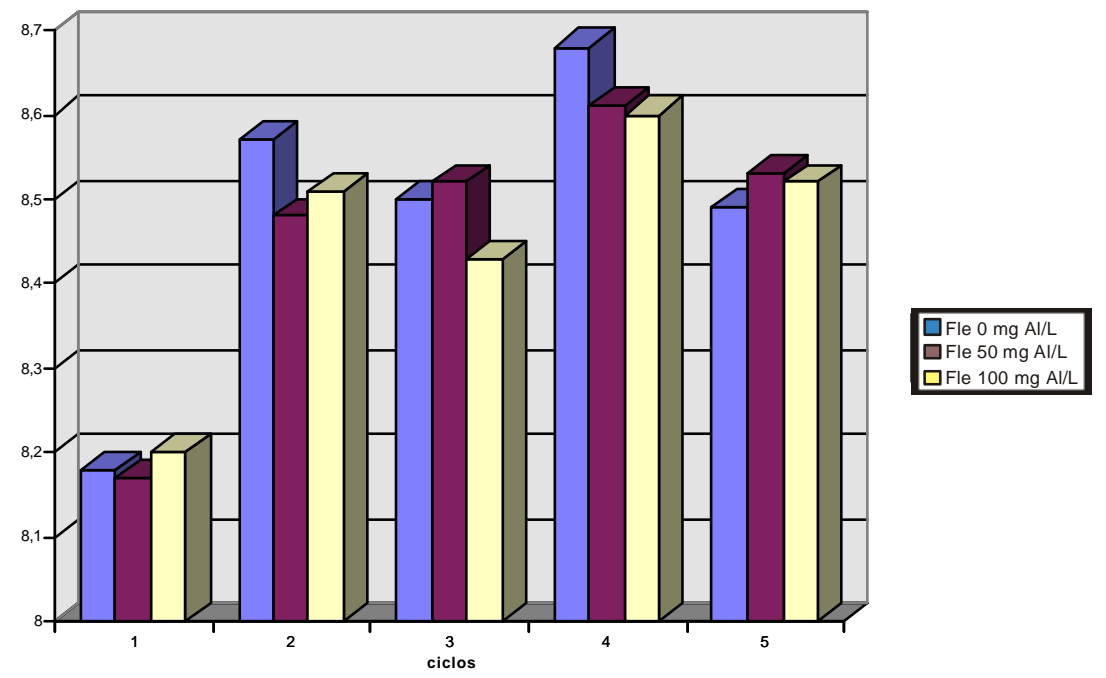

Figura 7 - Efeito de diferentes concentrações de alumínio (0, 50 e $100 \mathrm{mg} / \mathrm{L})$ sobre o crescimento $(\mathrm{g})$ da levedura Fleischmann, no transcorrer de 5 ciclos fermentativos, empregando-se a levedura Fleischmann e caldo de cana com $21,90 \%$ de ART (pH 5,0).

\subsubsection{Velocidade de fermentação}

A presença do alumínio no meio de fermentação acarretou redução na velocidade de fermentação até 7 horas, sendo mais intensa na maior dose de alumínio (Figura 8). 
VELOCIDADE DE FERMENTAÇÃO ( $\mathrm{g}$ CO2)

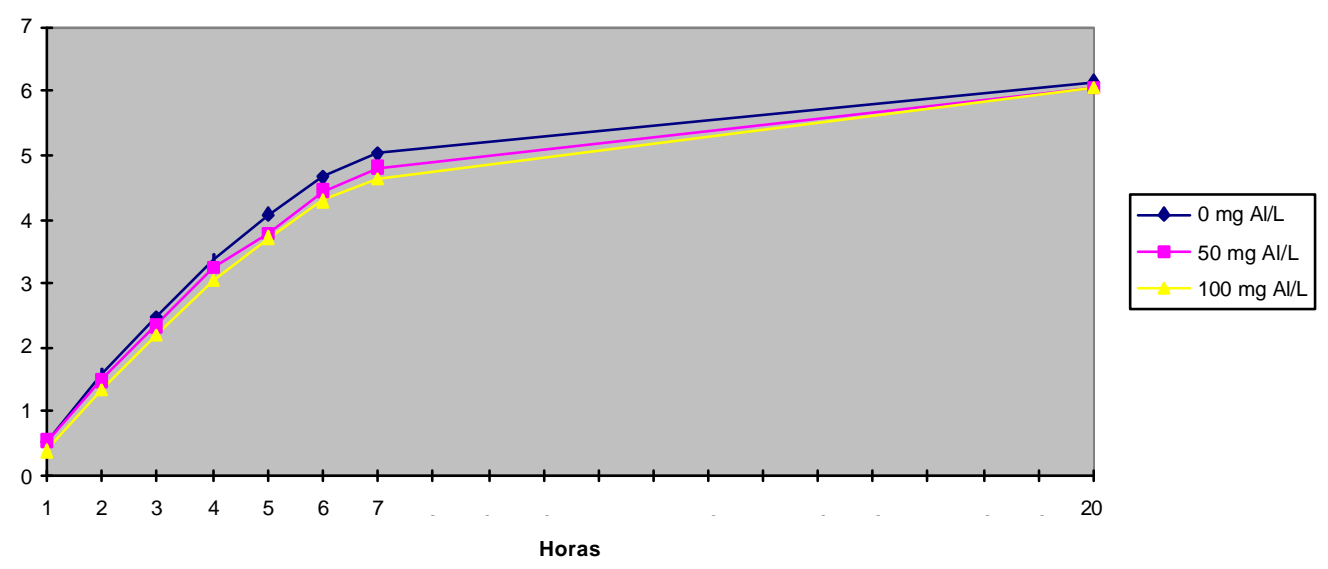

Figura 8 - Efeito de diferentes concentrações de alumínio (0, 50 e 100 mg/L) sobre a velocidade de fermentação ( $\mathrm{g}$ de $\mathrm{CO}_{2}$ ), empregando-se a levedura Fleischmann e caldo de cana com $21,90 \%$ de ART $(\mathrm{pH} \mathrm{5,0).}$

\subsubsection{Glicerol}

A formação de glicerol foi elevada no primeiro ciclo, para todos os tratamentos, porém, nos demais ciclos, se mostrou com elevação discreta na presença do alumínio (Figura 9), embora sem significância estatística. 


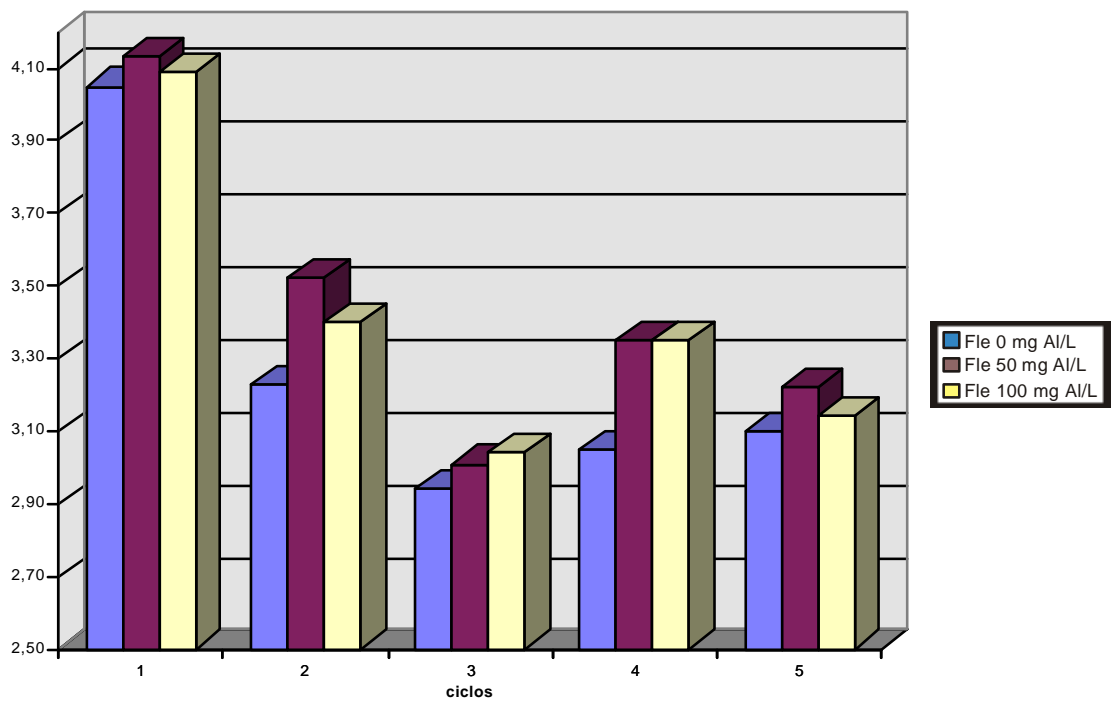

Figura 9 - Efeitos de diferentes concentrações de alumínio (0, 50 e 100 mg/L) sobre a formação de glicerol ( $\mathrm{g} / 100 \mathrm{~g}$ ART) no transcorrer de 5 ciclos fermentativos, empregando-se a levedura Fleischmann e caldo de cana com 21,9\% de ART (pH 5,0).

\subsubsection{Glicogênio e trealose}

No experimento 2 ocorreram menores acúmulos de trealose e glicogênio na presença de alumínio (Quadro 4), sugerindo uma situação estressante imposta pela presença do alumínio.

Lillie \& Pringle (1980) demonstraram que o padrão de acúmulo de trealose e glicogênio não são idênticos em condições de carência nutricional e sugeriram que a trealose tivesse outra função adicional, além de carboidrato de reserva. $A$ função suplementar da trealose possivelmente seria de manter a integridade das células perante as condições adversas de temperatura, acidez e concentrações elevadas de álcool (D’amore et al., 1991). Em tais condições a trealose seria metabolizada, tendo os seus conteúdos reduzidos. 


\begin{tabular}{|c|c|c|c|c|}
\hline TRATAMENTOS & \multicolumn{2}{|c|}{ TREALOSE } & \multicolumn{2}{|c|}{ GLICOGÊNIO } \\
\cline { 2 - 5 } AI(mg/L) & \multicolumn{4}{|c|}{$\%$} \\
\hline \multirow{2}{*}{ FLE } & INIC. & FIN. & INIC. & FIN. \\
\cline { 2 - 5 } $\mathbf{0}$ & 10,73 & 3,28 & 22,26 & 9,19 \\
\hline $\begin{array}{c}\text { FLE } \\
\mathbf{5 0}\end{array}$ & 10,73 & 2,46 & 22,26 & 7,42 \\
\hline FLE & & & & \\
$\mathbf{1 0 0}$ & 10,73 & 2,37 & 22,26 & 6,62 \\
\hline
\end{tabular}

Quadro 4 - Efeitos de diferentes concentrações de alumínio (0, 50 e $100 \mathrm{mg} / \mathrm{L})$ sobre os teores de trealose (\% na matéria seca) e glicogênio (\%), nos fermentos do início do ensaio e do final do último ciclo, empregando-se a levedura Fleischmann e mosto caldo de cana com $21,9 \%$ de ART (pH 5,0).

\subsubsection{Viabilidade celular}

Observou-se redução significativa da viabilidade celular na dose de 100 mg/L (Figura 10). 


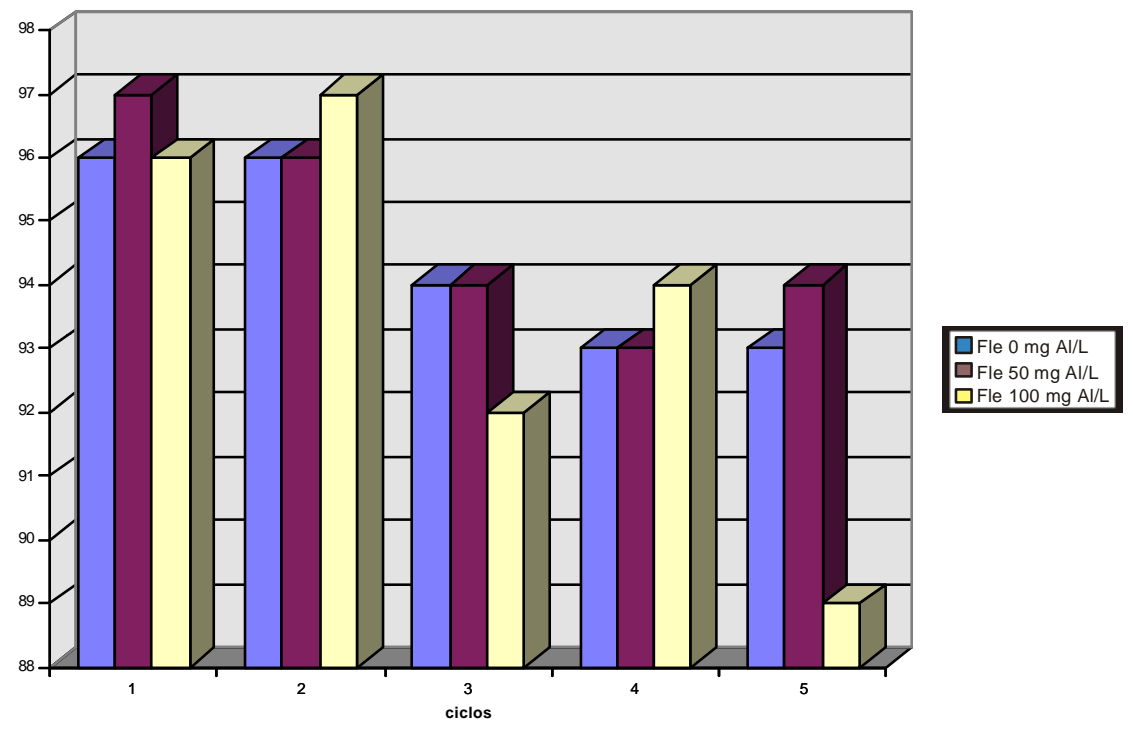

Figura 10 - Efeitos de diferentes concentrações de alumínio (0, 50 e 100 mg/L) sobre a viabilidade da levedura Fleischmann (\%), no transcorrer de 5 ciclos fermentativos, empregando-se caldo de cana com 21,9\% de ART (pH 5,0).

\subsubsection{Contaminação bacteriana}

O alumínio presente no meio de fermentação não alterou o padrão de crescimento de bactérias contaminantes (Quadro 5). 


\begin{tabular}{|c|c|c|c|c|c|c|}
\hline $\begin{array}{c}\text { TRTAMENTOS } \\
\text { Al (mg/L) }\end{array}$ & \multicolumn{5}{|c|}{$\begin{array}{c}\text { BACTÉRIAS } \\
(\mathrm{ces} / \mathrm{ml} \times 10>6)\end{array}$} \\
\hline \multirow{2}{*}{$\begin{array}{c}\text { FLE } \\
0\end{array}$} & Bci & Bc1 & Bc2 & Bc3 & Bc4 & Bc5 \\
\cline { 2 - 7 } & $<0,10$ & 0,33 & $<0,10$ & $<0,10$ & 0,43 & 0,26 \\
\hline $\begin{array}{c}\text { FLE } \\
50\end{array}$ & $<0,10$ & 0,42 & 0,17 & 0,24 & 0,17 & 0,17 \\
\hline $\begin{array}{c}\text { FLE } \\
100\end{array}$ & $<0,10$ & 0,40 & 0,17 & $<0,10$ & 0,33 & 0,24 \\
\hline
\end{tabular}

Quadro 5 - Efeitos de diferentes concentrações de alumínio (0, 50 e $100 \mathrm{mg} / \mathrm{L})$ sobre a contaminação bacteriana (cels/ml $\times 10^{6}$ ), no transcorrer de 5 ciclos fermentativos, empregando-se caldo de cana diluído a 21,9\% de ART e pH 5,0 .

\subsubsection{Acúmulo de alumínio nas células}

Houve acúmulo de alumínio nas células de leveduras quando o metal estava presente no meio de fermentação, sendo tal acúmulo dependente da dose do mesmo e da exposição (Quadro 6).

A análise realizada no mosto testemunha resultou em $5 \mathrm{mg} \mathrm{Al} / \mathrm{L}$. 


\begin{tabular}{|c|c|c|}
\hline TRATAMENTO & \multicolumn{2}{|c|}{ mgAl/Kg M.S. } \\
\cline { 2 - 3 } Al mg/L & INICIAL & $\mathbf{3}^{\circ}$ ciclo \\
\hline FLE 0 & 290 & 330 \\
\hline FLE 50 & 290 & 640 \\
\hline FLE 100 & 290 & 1230 \\
\hline
\end{tabular}

Quadro 6 - Efeitos de diferentes concentrações de alumínio (0, 50 e 100mg/L) sobre o acúmulo de alumínio nas células, no transcorrer de 5 ciclos fermentativos, empregando-se caldo de cana diluído a $21,9 \%$ de ART e pH 5,0.

\subsubsection{Considerações sobre o experimento 2}

Igualmente, se observou ação tóxica do alumínio, muito discreta, caracterizada por elevação no rendimento em etanol, reduções nos conteúdos de trealose e glicogênio, redução na velocidade de fermentação e pequena queda de viabilidade, esta apenas na maior dose de alumínio. Os demais parâmetros não foram alterados. Embora nos mostos não tenha sido adicionado ácido cítrico (como no meio semi-sintético), o ácido transaconítico existente no caldo de cana (Gutierrez,1989), poderia estar complexando o alumínio. Tal ácido orgânico pode ser encontrado em diferentes teores, variando especialmente em função da fertilização potássica do solo (Gutierrez, 1989).

Como no experimento 1 , também o $\mathrm{pH}$ do mosto foi ajustado a 5,0, sendo que tais fatores puderam contribuir para minimizar a ação tóxica do alumínio. 


\subsection{Experimento 3}

Utilizou-se mosto de caldo, $\mathrm{pH}$ 4,5 com 0, 50 e $100 \mathrm{mg} \mathrm{Al} / \mathrm{L}$, empregandose a levedura Fleischmann.

\subsubsection{Rendimento em etanol}

Foi levemente aumentado pela presença do alumínio no mosto, com significância estatística (Figura 11).

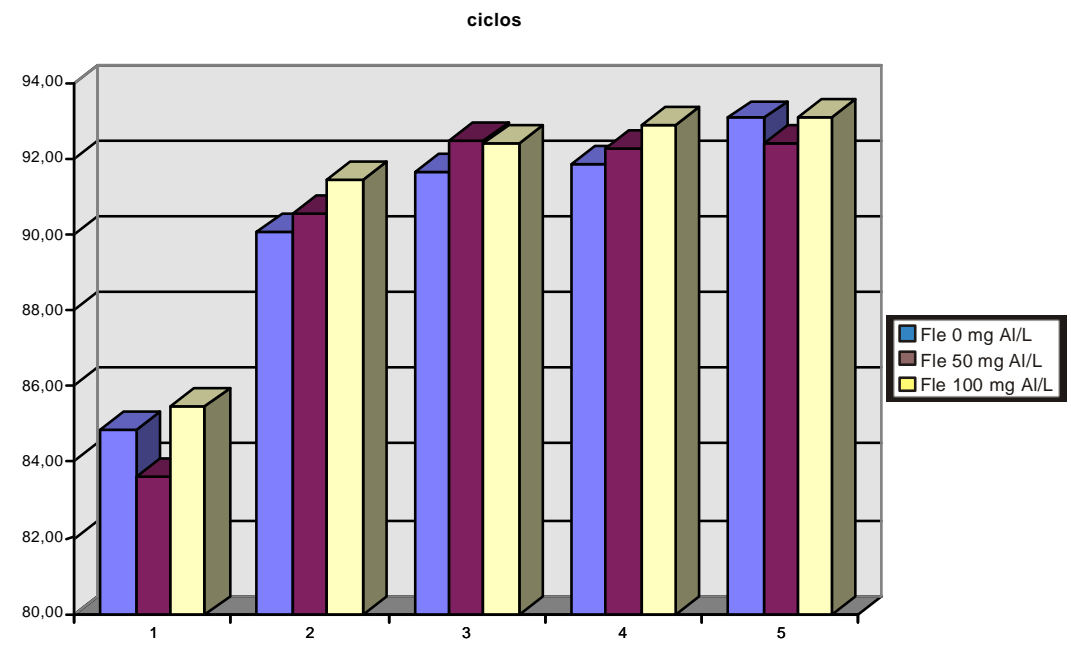

Figura 11 - Efeito de diferentes concentrações de alumínio (0,50 e $100 \mathrm{mg} / \mathrm{L})$ sobre o rendimento fermentativo (\%), no transcorrer de 5 ciclos fermentativos, empregando-se caldo de cana diluído a $20,20 \%$ de ART e pH 4,5 . 


\subsubsection{Crescimento em biomassa}

Houve um crescimento contínuo da biomassa de levedura com o progredir dos reciclos, porém sem diferenças estatísticas entre os tratamentos (Figura 12).

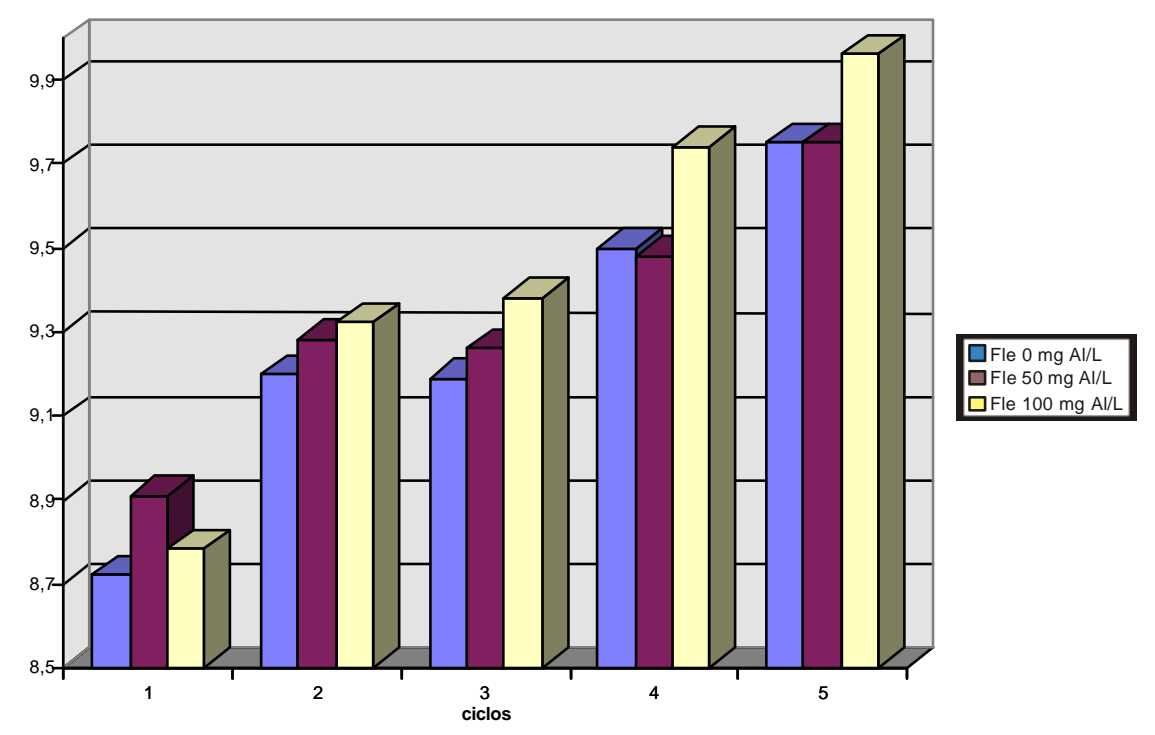

Figura 12 - Efeito de diferentes concentrações de alumínio (0, 50 e $100 \mathrm{mg} / \mathrm{L})$ sobre o crescimento $(\mathrm{g})$ da levedura FLE, no transcorrer de 5 ciclos fermentativos, empregando-se caldo diluído a $20,20 \%$ de ART e pH 4,5.

\subsubsection{Velocidade da fermentação}

A presença do alumínio no meio de cultura acarretou redução na velocidade de fermentação até 7 horas (Figura 13). 
VELOCIDADE DE FERMENTAÇÃO ( $\mathrm{g}$ CO2)

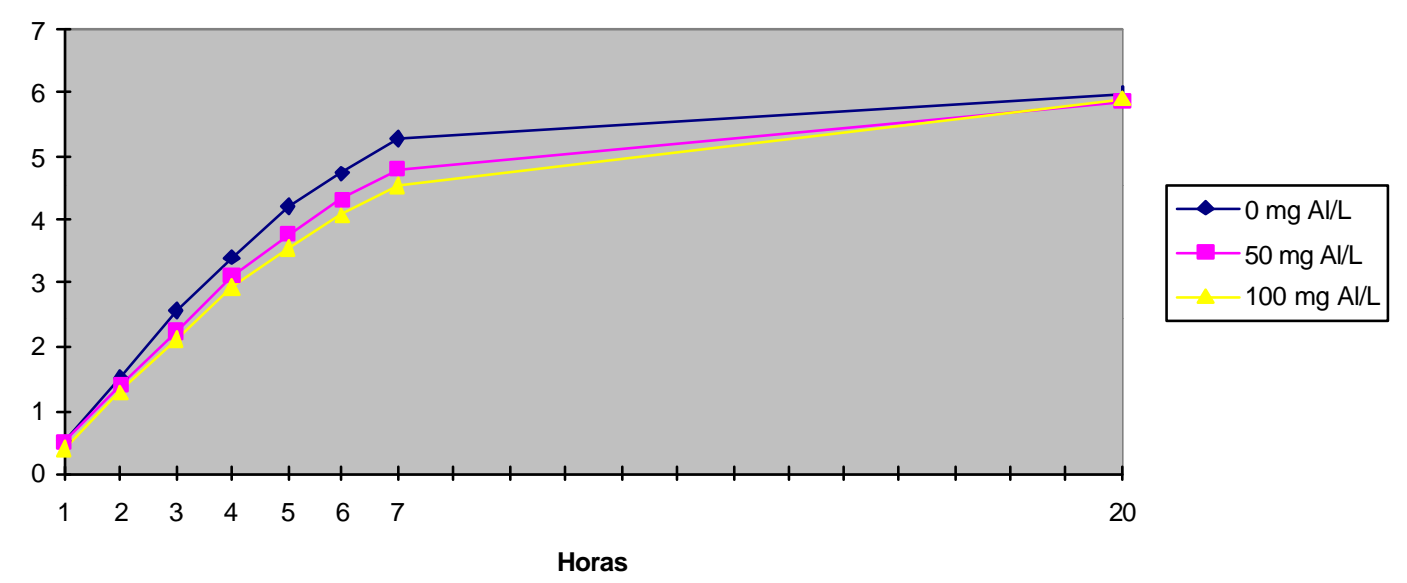

Figura 13 - Efeito de diferentes concentrações de alumínio (0,50 e $100 \mathrm{mg} / \mathrm{L})$ sobre a velocidade de fermentação, empregando-se a levedura FLE e caldo de cana com 20,20 de ART (pH 4,5).

\subsubsection{Glicerol}

A elevada formação de glicerol no primeiro ciclo fermentativo foi sendo paulatinamente reduzida nos ciclos subsequentes para todos os tratamentos (Figura 14), não ocorrendo alterações significativas em função da presença de alumínio no meio de fermentação. 


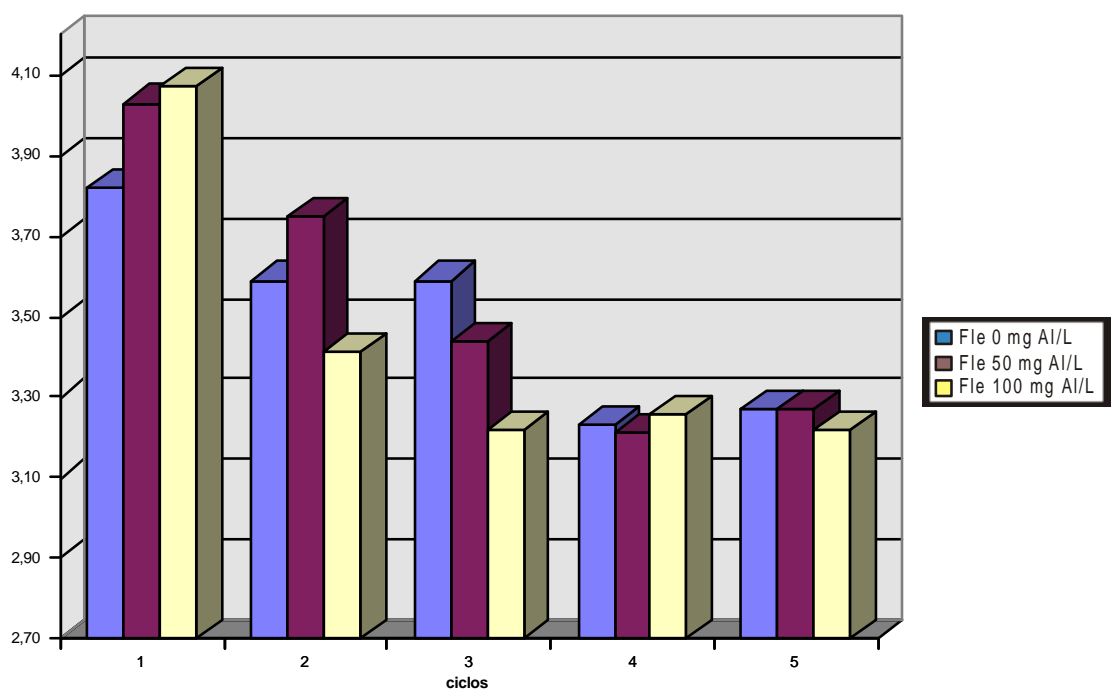

Figura 14 - Efeitos de diferentes concentrações de alumínio (0, 50 e $100 \mathrm{mg} / \mathrm{L})$ sobre a formação de glicerol ( $\mathrm{g} / 100 \mathrm{~g}$ ART) no transcorrer de 5 ciclos fermentativos, empregando-se caldo de cana diluído a 20,20 \% de ART e pH 4,5.

\subsubsection{Glicogênio e trealose}

Ocorreram reduções discretas nos conteúdos dos carboidratos de reserva, porém, com significância estatística apenas para a trealose (Quadro 7). 


\begin{tabular}{|c|c|c|c|c|}
\hline TRATAMENTOS & \multicolumn{2}{|c|}{ TREALOSE } & \multicolumn{2}{|c|}{ GLICOGÊNIO } \\
\cline { 2 - 5 } AI(mg/L) & \multicolumn{4}{|c|}{$\%$} \\
\hline FLE & INIC. & FIN. & INIC. & FIN. \\
\cline { 2 - 5 } $\mathbf{0}$ & 1,23 & 3,31 & 2,60 & 8,56 \\
\hline $\begin{array}{c}\text { FLE } \\
\mathbf{5 0}\end{array}$ & 1,23 & 2,23 & 2,60 & 7,87 \\
\hline $\begin{array}{c}\text { FLE } \\
\mathbf{1 0 0}\end{array}$ & 1,23 & 2,29 & 2,60 & 6,36 \\
\hline
\end{tabular}

Quadro 7 - Efeitos de diferentes concentrações de alumínio (0, 50 e $100 \mathrm{mg} / \mathrm{L})$ sobre os teores de trealose (\% na matéria seca) e glicogênio (\%), nos fermentos do início do ensaio e do final do último ciclo, empregando-se caldo de cana diluído a $20,20 \%$ de ART e pH 4,5.

\subsubsection{Viabilidade celular}

Houve reduções da viabilidade celular no transcorrer dos reciclos, porém mais acentuada para a dose de $100 \mathrm{mg}$ de $\mathrm{Al} / \mathrm{L}$, embora sem significância estatística (Figura 15). 


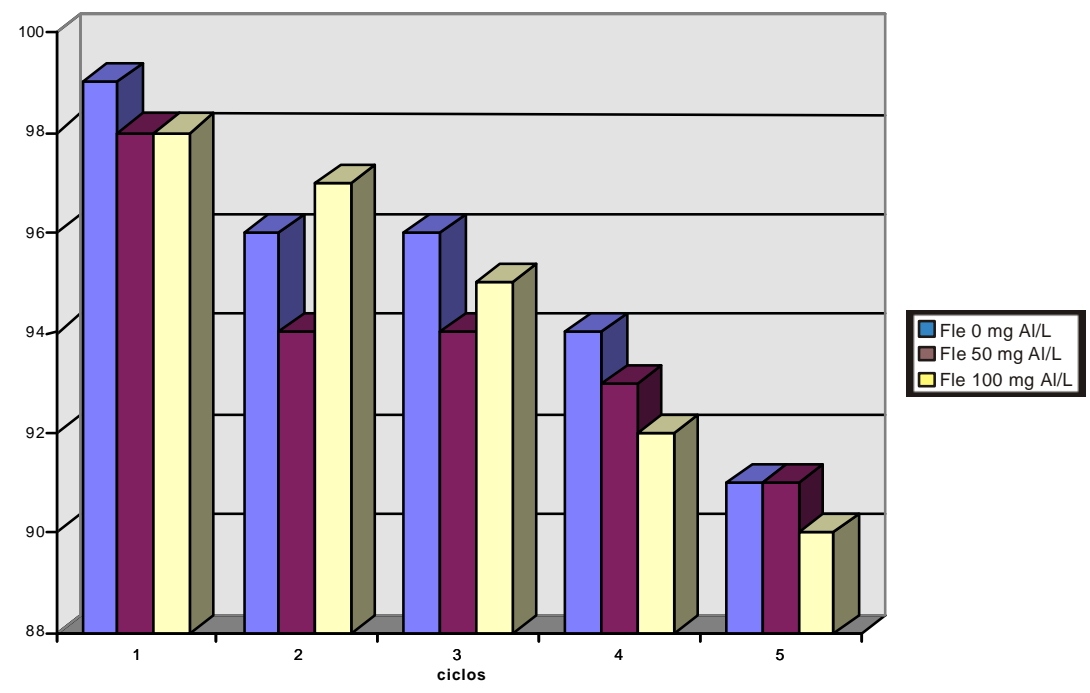

Figura 15 - Efeitos de diferentes concentrações de alumínio (0, 50 e 100 mg/L) sobre a viabilidade da levedura FLE (\%), no transcorrer de 5 ciclos fermentativos, empregando-se caldo diluído a 20,20 \% de ART e pH 4,5.

\subsubsection{Contaminação bacteriana}

O alumínio presente no meio de fermentação não alterou o padrão de crescimento de bactérias contaminantes (Quadro 8). 


\begin{tabular}{|c|c|c|c|c|c|c|}
\hline $\begin{array}{c}\text { TRTAMENTOS } \\
\text { Al }(\mathrm{mg} / \mathrm{L})\end{array}$ & \multicolumn{6}{|c|}{$\begin{array}{c}\text { BACTÉRIAS } \\
(\mathrm{ces} / \mathrm{ml} \times 10>6)\end{array}$} \\
\hline $\begin{array}{c}\text { FLE } \\
0\end{array}$ & $\mathrm{Bci}$ & $\mathrm{Bc} 1$ & $\mathrm{Bc} 2$ & $\mathrm{Bc3}$ & $\mathrm{Bc} 4$ & $\mathrm{Bc5}$ \\
\cline { 2 - 7 } & $<0,10$ & 0,24 & 0,33 & 0,66 & 0,17 & 0,21 \\
\hline $\begin{array}{c}\mathrm{FLE} \\
50\end{array}$ & $<0,10$ & 0,57 & 0,21 & 0,21 & 0,50 & 0,21 \\
\hline $\begin{array}{c}\text { FLE } \\
100\end{array}$ & $<0,10$ & 0,21 & 0,21 & 0,57 & 0,17 & 0,21 \\
\hline
\end{tabular}

Quadro 8 - Efeitos de diferentes concentrações de alumínio (0 ,50 e 100 mg/L) sobre a contaminação bacteriana (cels/ml $\times 10^{6}$ ), no transcorrer de 5 ciclos fermentativos, empregando-se caldo de cana diluído a 20,20 \% e pH 4,5.

\subsubsection{Acúmulo de alumínio nas células}

Houve acúmulo de alumínio em todos os tratamentos onde o metal estava presente no meio (Quadro 9), e igualmente promovido pela dose e tempo de exposição (reciclos).

A análise realizada no mosto testemunha resultou em $23 \mathrm{mg} \mathrm{Al} / \mathrm{L}$. 


\begin{tabular}{|c|r|r|r|}
\hline TRATAMENTO & \multicolumn{3}{|c|}{ mgAl/Kg M.S. } \\
\cline { 2 - 4 } Al mg/L & INICIAL & 3o ciclo & 5o ciclo \\
\hline FLE 0 & 80 & 240 & 220 \\
\hline FLE 50 & 80 & 420 & 620 \\
\hline FLE 100 & 80 & 610 & 1.150 \\
\hline
\end{tabular}

Quadro 9 - Efeitos de diferentes concentrações de alumínio (0, 50 e 100mg/L) sobre o acúmulo de alumínio nas células, no transcorrer de 5 ciclos fermentativos, empregando-se caldo de cana diluído a 20,20 \% de ART e pH 4,5.

\subsubsection{Considerações sobre o experimento 3}

A utilização do caldo de cana com pH menor $(4,5)$, não teve como consequência a exacerbação da toxidez do alumínio, quando comparado com o experimento 2, cujo $\mathrm{pH}$ foi de 5,0.

É provável que ainda nestas condições o efeito complexante do ácido transaconítico, presente no caldo, tenha contribuido para atenuar a ação deletéria do alumínio.

\subsection{Experimento 4}

Utilizou-se mosto semi-sintético, $\mathrm{pH} \mathrm{4,0,} \mathrm{com} 0$ e $100 \mathrm{mg} \mathrm{Al} / \mathrm{L}$, com as leveduras Fleischmann e PE-2. 


\subsubsection{Rendimento em etanol}

Neste experimento o rendimento fermentativo foi mais elevado para a levedura PE-2, mas pouco afetado pela presença do alumínio (Figura 16). A levedura Fleischmann mostrou queda acentuada da eficiência fermentativa, notadamente a partir do 4ำ ciclo fermentativo, sendo que a presença do alumínio no mosto acentuou tal queda.

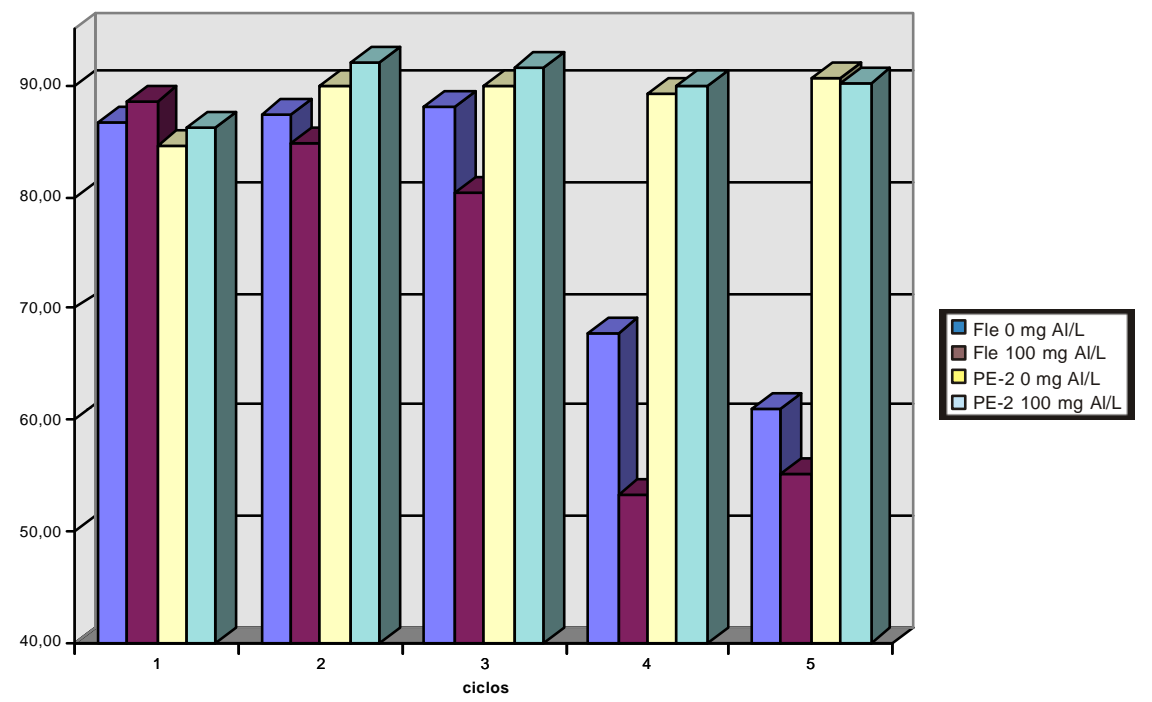

Figura 16 - Efeito de diferentes concentrações de alumínio (0 e $100 \mathrm{mg} / \mathrm{L}$ ) sobre 0 rendimento fermentativo (\%), no transcorrer de 5 ciclos fermentativos, empregando-se mosto semi-sintético com 21,87 de ART e pH 4,0, empregando-se as leveduras Fleischmann e PE-2. 


\subsubsection{Crescimento em biomassa}

Embora ambas as leveduras tenham iniciado o ensaio com a mesma quantidade de biomassa $(7 \mathrm{~g})$, as fermentações finalizaram-se com menores quantidades de células no caso da levedura Fleischmann (Figura 17). A levedura PE-2 manteve o teor de biomassa praticamente constante durante os reciclos e sem alterações pela presença do alumínio no mosto.

No entanto a levedura Fleischmann mostrou discreta redução nos teores de biomassa até o $3^{\circ}$ ciclo, quando da presença do alumínio no mosto.

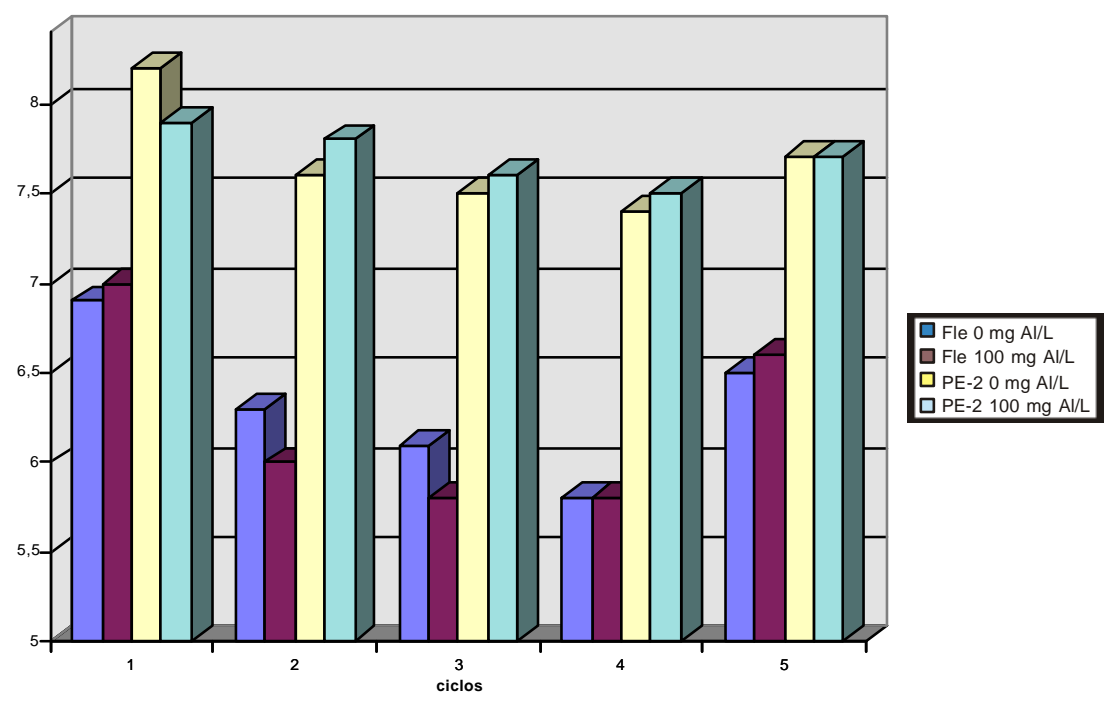

Figura 17 - Efeito de diferentes concentrações de Al (0 e $100 \mathrm{mg} / \mathrm{L}$ ) sobre o crescimento (g) das leveduras FLE e PE-2, no transcorrer de 5 ciclos fermentativos,empregando-se mosto semi-sintético com 21,87\% de ART, pH 4,0, empregando-se as leveduras Fleischmann e PE-2. 


\subsubsection{Velocidade da fermentação}

A presença do alumínio no meio fermentativo acarretou redução na velocidade de fermentação até 7 horas, exceto para a levedura PE-2, a qual apresentou valores semelhantes em ambos os tratamentos (Figura 18).

Sendo a glicose-6P produzida a partir da glicose + ATP em presença de $\mathrm{Mg}$, em reação catalisada pela enzima hexoquinase, pode-se relacionar a queda na velocidade de fermentação com o relato de Martim (1992) de que o complexo $\mathrm{Al}^{+3}+\mathrm{ATP}$ se liga àenzima hexoquinase 1000 vezes mais fortemente em relação ao complexo Mg-ATP promovendo, portanto, inibição da reação.

LIBERAÇÃO DE CO2 (g)

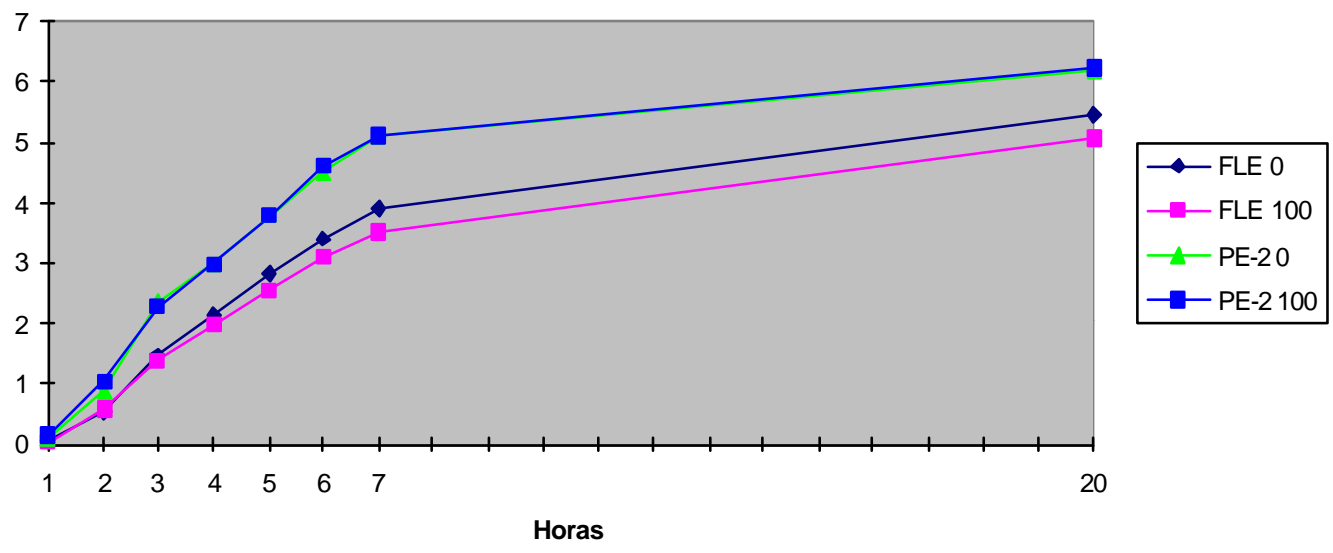

Figura 18 - Efeito de diferentes concentrações de alumínio (0 e $100 \mathrm{mg} / \mathrm{L}$ ) sobre a velocidade de fermentação ( $\mathrm{g}$ de $\mathrm{CO}_{2}$ ), empregando-se as leveduras FLE e PE-2 e mosto semi-sintético com $21,87 \%$ de ART, pH 4,0, com as leveduras Fleischmann e PE-2. 


\subsubsection{Glicerol}

Neste experimento a produção de glicerol mostrou-se em níveis diferentes para ambas as linhagens, sendo extremamente elevada na presença do alumínio para a levedura Fleischmann (Figura 19). A formação exacerbada de glicerol pode estar refletindo uma situação de estresse, muito mais intensa para a levedura Fleischmann comparada com a PE-2, conforme relatado por Alves (2000).

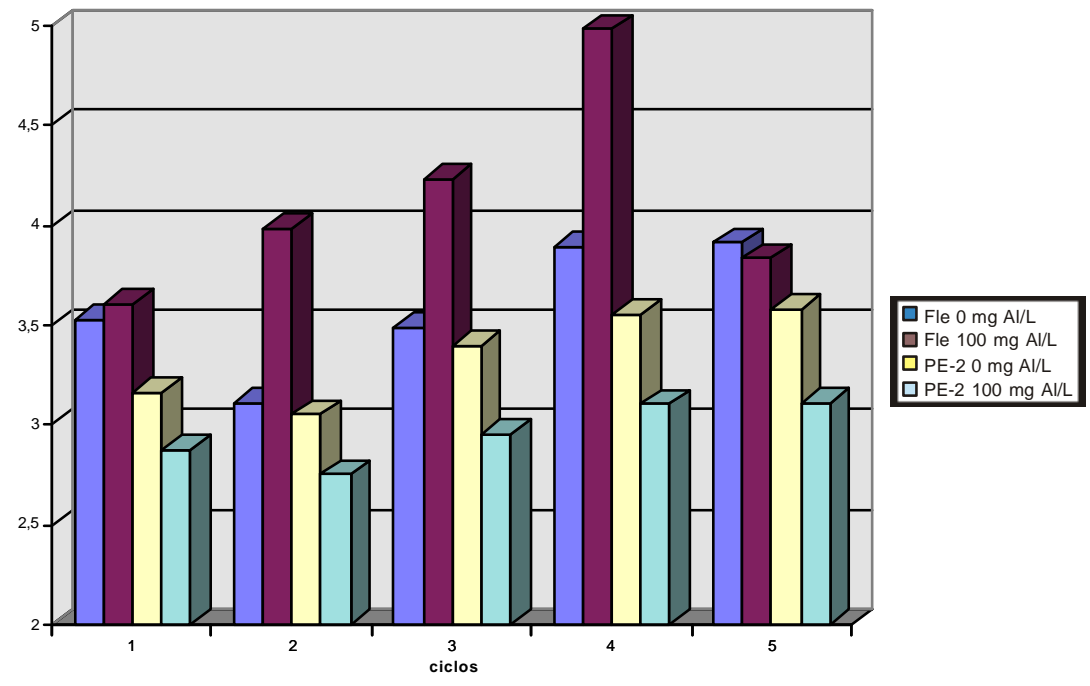

Figura 19 - Efeitos de diferentes concentrações de alumínio (0 e $100 \mathrm{mg} / \mathrm{L}$ ) sobre a formação de glicerol (g/100g ART) no transcorrer de 5 ciclos fermentativos, empregando-se mosto semi-sintético com $21,87 \%$ de ART, pH 4,0, com as leveduras Fleiscmann e PE-2. 


\subsubsection{Glicogênio e trealose}

Os teores dos carboidratos de reserva (glicogênio e trealose) foram sempre menores para a levedura Fleischmann, tanto no início do ensaio como no final do último ciclo (Quadro 7). No entanto, neste experimento, a presença do alumínio nos mostos não promoveu reduções nos teores desses carboidratos de modo significativo.

\begin{tabular}{|c|c|c|c|c|}
\hline TRATAMENTOS & \multicolumn{2}{|c|}{ TREALOSE } & \multicolumn{2}{c|}{ GLICOGÊNIO } \\
\cline { 2 - 5 } Al(mg/L) & \multicolumn{4}{|c|}{$\%$} \\
\hline \multirow{2}{*}{$\begin{array}{c}\text { FLE } \\
\mathbf{0}\end{array}$} & INIC. & FIN. & INIC. & FIN. \\
\cline { 2 - 5 } & 4,30 & 3,40 & 3,40 & 6,50 \\
\hline $\begin{array}{c}\text { FLE } \\
\mathbf{1 0 0}\end{array}$ & 4,30 & 3,80 & 3,40 & 5,00 \\
\hline $\begin{array}{c}\text { PE-2 } \\
\mathbf{0}\end{array}$ & 5,70 & 5,90 & 9,50 & 14,40 \\
\hline $\begin{array}{c}\text { PE-2 } \\
\mathbf{1 0 0}\end{array}$ & 5,70 & 6,10 & 9,50 & 12,70 \\
\hline
\end{tabular}

Quadro 10 - Efeitos de diferentes concentrações de alumínio (0 e $100 \mathrm{mg} / \mathrm{L}$ ) sobre os teores de trealose (\% na matéria seca) e glicogênio (\%), nos fermentos do início do ensaio e do final do último ciclo, empregando-se mosto semisintético com $21,87 \%$ de ART e pH 4,0.

\subsubsection{Viabilidade celular}


A viabilidade celular sofreu redução constante ao longo dos reciclos, sendo tal queda mais acentuada para a levedura Fleischmann (Figura 20). Enquanto a presença do alumínio pouco afetou tal parâmetro para a levedura PE-2, a presença do metal induziu maior queda de viabilidade na levedura Fleischmann. Tal constatação sugere que a levedura PE-2 seja mais tolerante que a Fleischmann àação tóxica do alumínio.

Para esse parâmetro, os trabalhos realizados por Basso (1990) e Basso (1991), fermentando mosto sintético, mostraram drástica queda de viabilidade nos tratamentos com alumínio, especialmente nos tratamentos com $100 \mathrm{mg} / \mathrm{L}$.

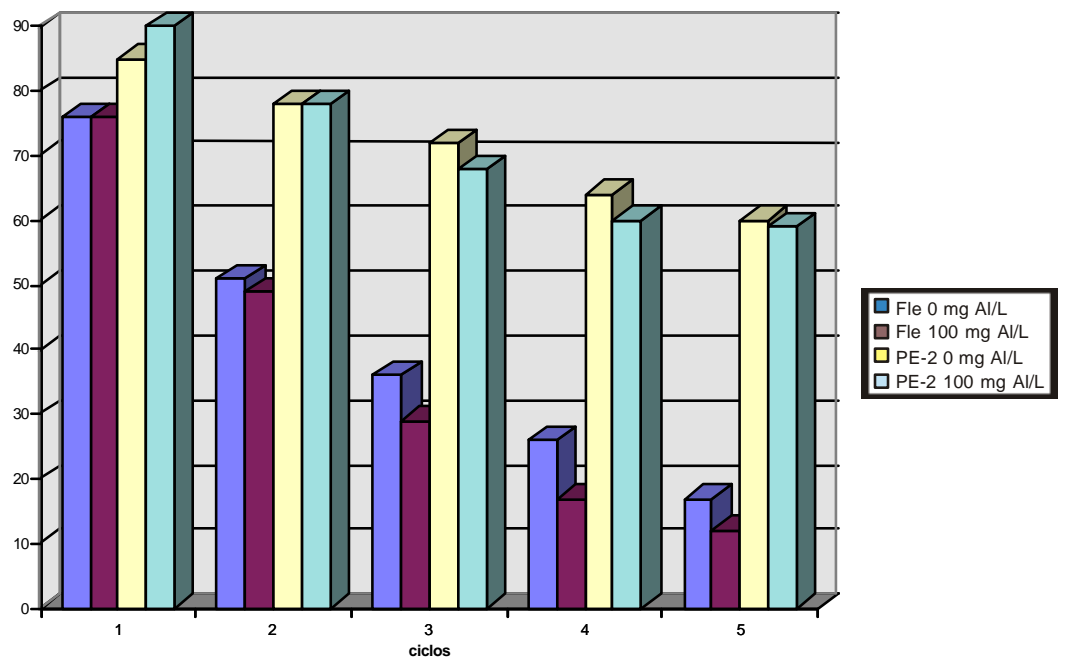

Figura 20 - Efeitos de diferentes concentrações de alumínio (0 e $100 \mathrm{mg} / \mathrm{L}$ ) sobre a viabilidade das leveduras FLE e PE-2 (\%), no transcorrer de 5 ciclos fermentativos, empregando-se mosto semi-sintético com $21,87 \%$ de ART e $\mathrm{pH} 4,0$. 


\subsubsection{Contaminação bacteriana}

Embora os resultados não tenham sido apresentados, a presença do alumínio nos mostos não interferiu nesse parâmetro em ambas as leveduras, mantendo-se em níveis menores que $0,1 \times 10^{6} \mathrm{cels} / \mathrm{ml}$.

\subsubsection{Acúmulo de alumínio nas células}

Houve acúmulo de alumínio nas células de ambas as linhagens, sendo tal acúmulo igualmente dependente do tempo de exposição (Quadro 8). No entanto tal acúmulo foi mais intenso na levedura Fleischmann, podendo-se supor que a maior vulnerabilidade aos efeitos tóxicos do metal nesta levedura seja decorrência de uma maior adsorção/absorção do que aquela observada com a levedura PE-2.

A análise realizada no mosto testemunha resultou em $7 \mathrm{mg} \mathrm{Al} / \mathrm{L}$. 


\begin{tabular}{|c|r|r|r|}
\hline TRATAMENTO & \multicolumn{3}{|c|}{ mgAl/Kg M.S. } \\
\cline { 2 - 4 } Al mg/L & INICIAL & 3 ciclo & 50 ciclo \\
\hline FLE 0 & 450 & 637 & 813 \\
\hline FLE 100 & 450 & 4.070 & 4.217 \\
\hline PE-2 0 & 520 & 640 & 737 \\
\hline PE-2 100 & 520 & 2.190 & 2.417 \\
\hline
\end{tabular}

Quadro 11 - Efeitos de diferentes concentrações de alumínio (0 e 100mg/L) sobre o acúmulo de alumínio nas células, no transcorrer de 5 ciclos fermentativos, empregando-se mosto semi-sintético com 21,87\% de ART, $\mathrm{pH} 4,0$, com as leveduras Fleischmann e PE-2.

\subsubsection{Considerações sobre o experimento 4}

Em tal experimento, tornaram-se mais evidentes as diferenças fisiológicas entre as duas linhagens testadas (Alves, 2000) do que os efeitos deletérios do alumínio sobre a fermentação com reciclos. Assim, o alumínio causou reduções discretas no rendimento em etanol e na viabilidade celular, com concomitante incremento na formação de glicerol no caso da levedura Fleischmann, mas pouco afetou os parâmetros estudados na levedura Pedra 2. Uma outra característica marcante difere as duas linhagens estudadas: a levedura Fleischmann acumulou 
maiores quantidades de alumínio no transcorrer dos reciclos e se mostrou mais vulnerável aos efeitos deletérios do metal.

O alumínio já foi encontrado em quantidades potencialmente tóxicas nos substratos industriais (Basso, 1989) e como a levedura Fleischmann tem duração efêmera em ambiente de dorna nas destilariras (Basso et al, 1993) é provável que a toxidez pelo alumínio contribua para a não permanência desta levedura em fermentações industriais.

\subsection{Considerações gerais sobre a ação do alumínio em fermentação com reciclo}

O alumínio presente nos mostos alterou o balanço de massa das fermentações, promovendo diminuição na formação de biomassa, desviando, em alguns casos, açúcar para uma maior produção de etanol.

A produção de biomassa em anaerobiose está acoplada àformação de

glicerol, mas esse poliol também pode refletir situações de estresse à levedura (Alves, 2000). Assim, nos ensaios conduzidos, menores crescimentos acarretariam menor formação de gilcerol, mas, a levedura, estando sob estresse do alumínio, poderia intensificar a síntese do mesmo, dificultando dessa maneira a interpretação dos resultados. No entanto a ação tóxica do alumínio foi mais discreta do que aquela já observada em trabalhos anteriores, e não se tendo os teores dos ácidos orgânicos (especialmente o transaconítico nos mostos de caldo), se torna difícil uma interpretação dos resultados. 


\section{CONCLUSÕES}

A ação tóxica do alumínio, embora discreta, é caracterizada por redução na formação de biomassa, desviando mais açúcar para a produção de etanol. A viabilidade celular é diminuida, possivelmente pelas reduções nos teores de trealose e glicogênio.

O acúmulo de alumínio nas células é promovido tanto pelo teor do elemento no mosto, como pela exposição e tal acúmulo é mais acentuado para a levedura Fleischmann, quando contrastada com a levedura PE-2. 
ANEXO A: Quadros 


\begin{tabular}{|c|c|c|c|c|c|c|c|}
\hline 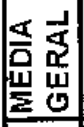 & & & 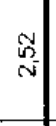 & & is & & $\stackrel{\infty}{:}$ \\
\hline \multirow{6}{*}{ 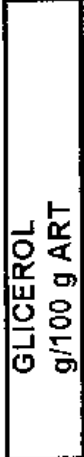 } & 0 & 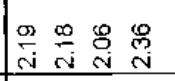 & ్ㅗ & 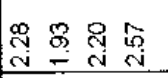 & בֶّ & 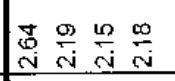 & הి \\
\hline & 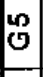 & 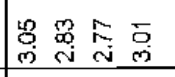 & శ్ & 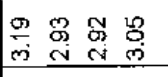 & 今్ & 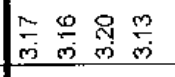 & ले \\
\hline & : & 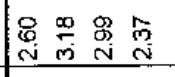 & $\stackrel{9}{\sim}$ & $\begin{array}{l}0 \\
0 \\
0 \\
m \\
m\end{array}$ & 总 & 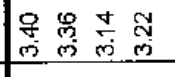 & 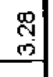 \\
\hline & 0 & 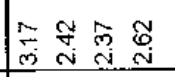 & 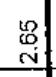 & Nָ & $\stackrel{\circ}{\sim}$ & 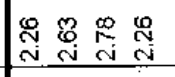 & $\stackrel{g}{\mathrm{~g}}$ \\
\hline & $\mathbb{N}$ & 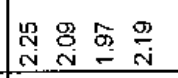 & $\stackrel{m}{\sim}$ & 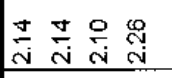 & $\stackrel{\circ}{\stackrel{\circ}{ }}$ & స̃ & $\stackrel{\circ}{\mathrm{N}}$ \\
\hline & 5 & 웠 & 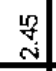 & 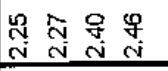 & ్ㅐㅁ & 点莡员 & نn. \\
\hline \multirow{7}{*}{\multicolumn{2}{|c|}{ 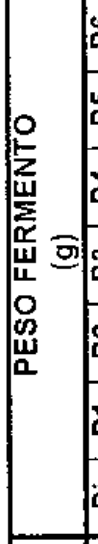 }} & 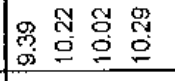 & $\begin{array}{l}\infty \\
8 \\
0 \\
\end{array}$ & 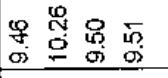 & 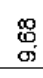 & 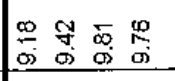 & $\begin{array}{l}5 \\
\vdots \\
0 \\
0\end{array}$ \\
\hline & & $\begin{array}{l}\qquad \\
\sigma \\
\sigma\end{array}$ & 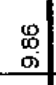 & $\begin{array}{l}0 \\
0 \\
0 \\
0\end{array}$ & 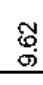 & 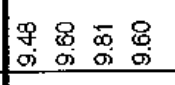 & \begin{tabular}{l}
0 \\
0 \\
0 \\
\hdashline
\end{tabular} \\
\hline & & 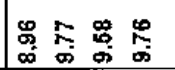 & న్రి & 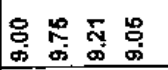 & 㟧 & 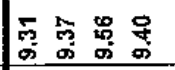 & $\underset{\sigma}{\sigma}$ \\
\hline & & 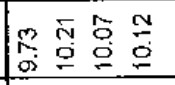 & $\begin{array}{l}8 \\
: \\
\end{array}$ & 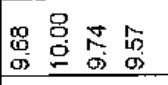 & 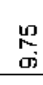 & 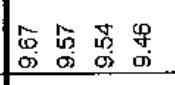 & \begin{tabular}{l}
$\infty$ \\
$:$ \\
$\infty$ \\
\hdashline \\
\end{tabular} \\
\hline & & 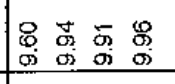 & 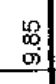 & 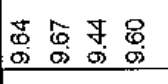 & 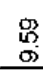 & 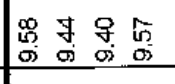 & 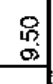 \\
\hline & & 式 & 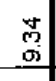 & 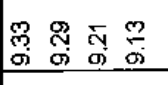 & $\underset{\sigma}{\mathbb{\sigma}}$ & ஸே & $\stackrel{\varphi}{\circ}$ \\
\hline & & $\begin{array}{llll}8 & 8 & 9 & 8 \\
0 & 0 & 0 \\
0 & 0 & 0 \\
0\end{array}$ & $\begin{array}{l}8 \\
\infty \\
\end{array}$ & $\begin{array}{llll} & 9 & 8 & 8 \\
00 & 8 & 8 \\
0 & 0 & 0 \\
0\end{array}$ & $\begin{array}{l}\stackrel{g}{\circ} \\
\infty\end{array}$ & $\begin{array}{llll}8 & 8 & 8 & 8 \\
0 & 0 & 8 \\
0 & 0 & 0 & 0 \\
\end{array}$ & $\begin{array}{l}8 \\
0 \\
0\end{array}$ \\
\hline 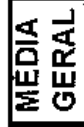 & & & 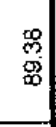 & & $\begin{array}{l}\text { o } \\
\text { o. } \\
\text { o. }\end{array}$ & & $\begin{array}{l}\text { ज̦ } \\
\text { ğ }\end{array}$ \\
\hline \multirow{6}{*}{ 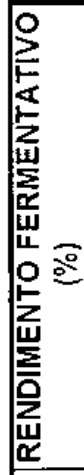 } & $\mathscr{\infty}$ & 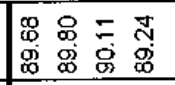 & $\begin{array}{l}5 \\
0 \\
0 \\
0\end{array}$ & 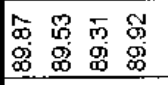 & $\begin{array}{l}: \\
\stackrel{8}{0} \\
\infty \\
\end{array}$ & 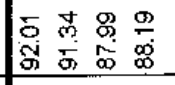 & 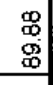 \\
\hline & \begin{tabular}{|l}
$\mathscr{2}$ \\
$\mathscr{L}$
\end{tabular} & 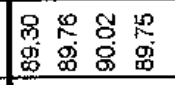 & $\begin{array}{r}5 \\
\text { 惒 } \\
\end{array}$ & 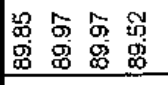 & 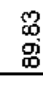 & 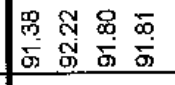 & $\begin{array}{c}\stackrel{8}{0} \\
\dot{0} \\
\end{array}$ \\
\hline & $\vec{x}$ & 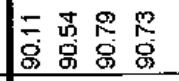 & 苟 & 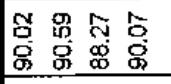 & 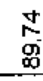 & 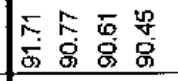 & 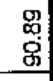 \\
\hline & 2 & 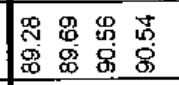 & $\begin{array}{l}0 \\
8 \\
\dot{8} \\
\end{array}$ & 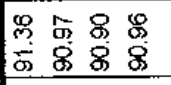 & $\stackrel{8}{\circ}$ & 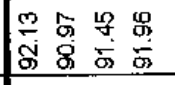 & $\begin{array}{l}0 \\
\frac{0}{0} \\
\end{array}$ \\
\hline & $\tilde{\Psi}$ & 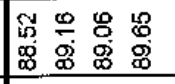 & 웅 & 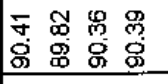 & $\stackrel{\text { L̊ }}{8}$ & 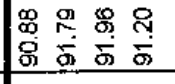 & $\begin{array}{l}\varphi \\
+ \\
\dot{\omega} \\
\end{array}$ \\
\hline & 平 & 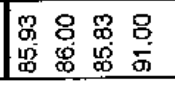 & $\begin{array}{c}0 \\
\stackrel{0}{\circ} \\
\infty \\
\end{array}$ & 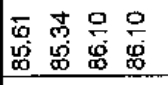 & 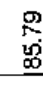 & 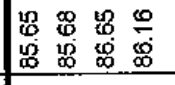 & $\begin{array}{l} \pm \\
0 \\
0 \\
0 \\
\end{array}$ \\
\hline 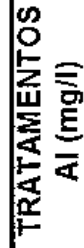 & & 0000 & 言 & 은 온용으 & 要 & 8 & $\begin{array}{l}\stackrel{\mathbf{\Delta}}{\mathbf{W}} \\
\stackrel{\mathrm{W}}{\Sigma}\end{array}$ \\
\hline
\end{tabular}

8 욜 \& 53

웅

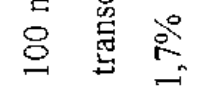

$\circ \cong \overline{\mathrm{N}}$

它

量的总

तु

욤

㱐

柋

莺

冚 용

号 苦

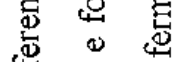

愛

품

总

包

올 


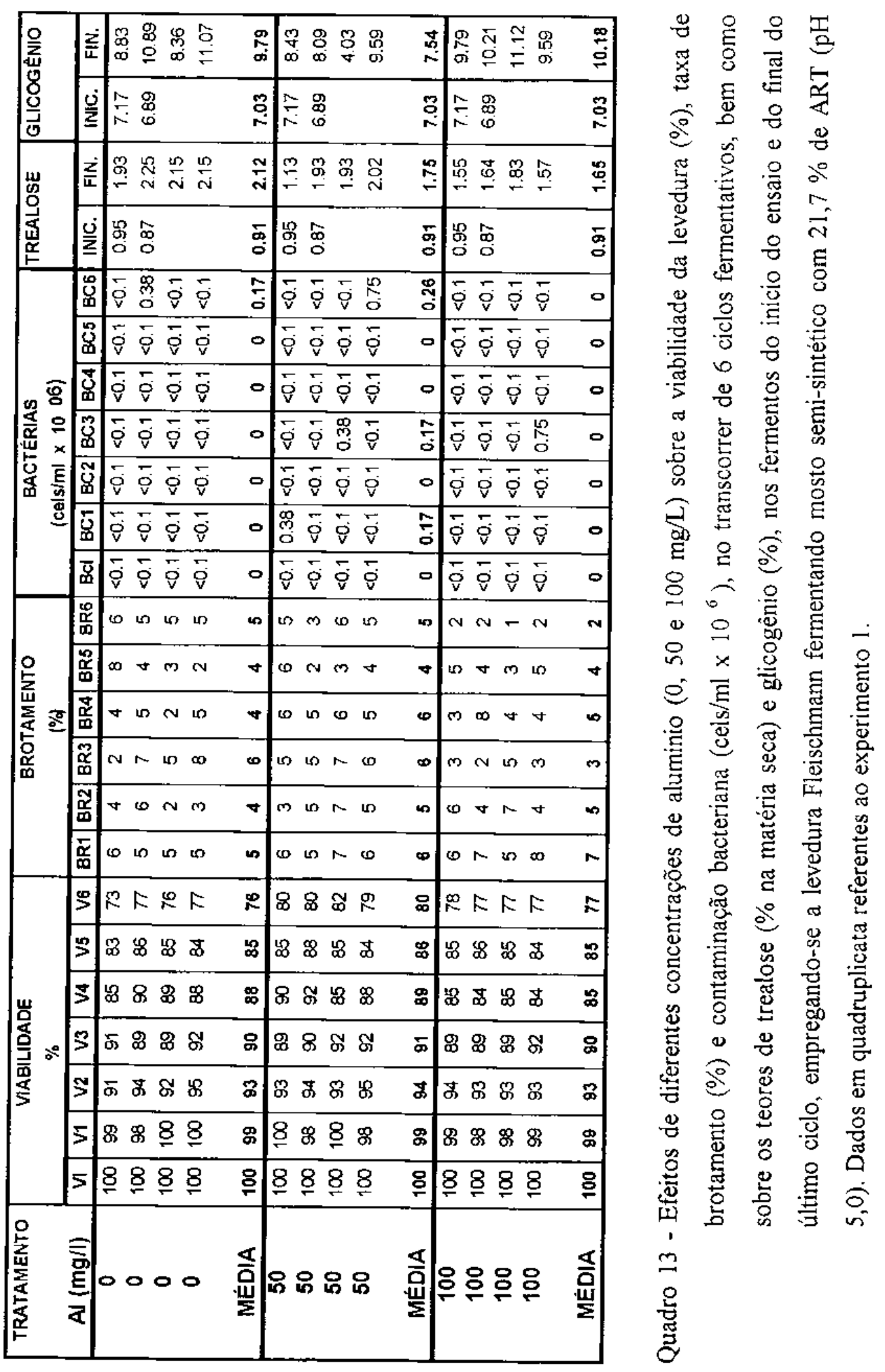




\begin{tabular}{|c|c|c|c|c|c|c|c|c|c|}
\hline \multirow{2}{*}{$\begin{array}{l}\text { TRATAMENTOS } \\
\text { Al mg/L }\end{array}$} & \multirow{2}{*}{$\begin{array}{l}\text { ciclo } \\
\left(\mathrm{N}^{\circ}\right)\end{array}$} & \multicolumn{8}{|c|}{ LIBERAÇÁO DE CO2(g) } \\
\hline & & $1 \mathrm{~h}$ & $2 \mathrm{~h}$ & $3 \mathrm{~h}$ & $4 \mathrm{~h}$ & $5 \mathrm{~h}$ & $6 \mathrm{~h}$ & $7 \mathrm{~h}$ & $20 \mathrm{~h}$ \\
\hline \multirow[t]{7}{*}{0} & $1^{\circ}$ & 0.63 & 1.58 & 3.05 & 3.66 & 4.50 & 5,16 & 5.65 & 5.94 \\
\hline & $2^{\circ}$ & 0.36 & 1.16 & 2.76 & 3.02 & 4.49 & 5.15 & 5.61 & 5.99 \\
\hline & $3^{\circ}$ & 0.48 & 158 & 2.97 & 3.64 & 4.35 & 5.28 & 5.53 & 6.06 \\
\hline & $4^{\circ}$ & 038 & 0.90 & 240 & 3.23 & 4.04 & 4.82 & 5.32 & 5.88 \\
\hline & $5^{\circ}$ & 0.56 & 1.71 & 3.12 & 4,16 & 492 & 5.50 & 5.87 & 6.12 \\
\hline & $6^{\circ}$ & 0.83 & 2.60 & 3.68 & 4.34 & 5.14 & 5,78 & 6.24 & 6.41 \\
\hline & mtou & 0.54 & 1.59 & 3.00 & 3.68 & 4.57 & 5.62 & 5.70 & 6.08 \\
\hline \multirow[t]{7}{*}{50} & $1^{\circ}$ & 0.45 & 1.51 & 2.81 & 333 & 4.18 & 4,87 & 5.46 & 6.02 \\
\hline & $2^{\circ}$ & 0.34 & 105 & 2.61 & 3.12 & 4.33 & 5.01 & 5.52 & 6.03 \\
\hline & $3^{\circ}$ & 0.30 & 1.27 & 260 & 3.25 & 3.98 & 5.01 & 5,55 & 6.02 \\
\hline & $4^{\circ}$ & 0.38 & 0.58 & 238 & 3.17 & 3.96 & 4.72 & 5.34 & 623 \\
\hline & $5^{\circ}$ & 0.45 & 1.42 & 286 & 3.82 & 462 & 5.25 & 5.64 & 5.87 \\
\hline & $6^{\circ}$ & 0.88 & 2.27 & 3.67 & 439 & 5.22 & 5.87 & 624 & 6.43 \\
\hline & $M \in D U A$ & 0.47 & 1.42 & 2.82 & 3.51 & 4.38 & 5.12 & 5.63 & 6.10 \\
\hline \multirow[t]{7}{*}{100} & $1^{\circ}$ & 0.31 & 1.45 & 2.80 & 3.28 & 4.11 & 477 & 5.33 & 6.00 \\
\hline & $2^{\circ}$ & 0.21 & 0.86 & 238 & 3.13 & 4.11 & 4.80 & 5,34 & 6.07 \\
\hline & $3^{\circ}$ & 0.24 & 1.19 & 250 & 3.14 & 3.82 & 4.86 & 5.59 & 631 \\
\hline & $4^{\circ}$ & 0.19 & 0.69 & 202 & 2.82 & 355 & 4.23 & 471 & 5.81 \\
\hline & $5^{\circ}$ & 0.43 & 1.43 & 2.84 & 3.79 & 459 & 5.24 & 5.72 & 6.02 \\
\hline & $6^{\circ}$ & 0.83 & 2.34 & 3.52 & 4.19 & 5.01 & 5.72 & 6.20 & 6.43 \\
\hline & MÉDIA & 0.37 & 1.33 & 2.68 & 3.39 & 4.20 & 4.94 & 5.48 & 6.21 \\
\hline
\end{tabular}

Quadro 14 - Evolução da fermentação avaliada pela perda de peso $\left(\mathrm{g} \mathrm{CO}_{2}\right)$ a cada hora, para diferentes concentraçōes de alumínio $(0,50$ e $100 \mathrm{mg} / \mathrm{L})$ empregando-se a levedura Fleischmann e mosto semi-sintético com $21,7 \%$ de ART ( $\mathrm{pH}$ 5). Cada dado representa a média de 4 repetições, referentes ao experimento 1 . 


\begin{tabular}{|c|c|c|c|}
\hline \multirow{2}{*}{$\begin{array}{c}\text { TRATAMENTO } \\
\text { Al mg/L }\end{array}$} & \multicolumn{3}{|c|}{ mg Al/g M.S. } \\
\cline { 2 - 4 } & INICIAL & $3^{\circ}$ & $6^{\circ}$ \\
ciclo & ciclo \\
\hline 0 & 0.52 & 0.81 & - \\
0 & 0.75 & 1.10 & 0.78 \\
0 & - & 0.61 & 1.04 \\
0 & - & 0.70 & 1.17 \\
MÉDIA & 0.64 & 0.81 & 1.00 \\
\hline 50 & 0.52 & 0.94 & 0.98 \\
50 & 0.75 & 0.87 & 1.94 \\
50 & - & 0.84 & 1.55 \\
50 & - & 0.63 & 2.26 \\
& & & 1.68 \\
\hline MÉDIA & 0.64 & 0.82 & 3.15 \\
\hline 100 & 0.52 & 1.10 & 3.49 \\
100 & 0.75 & 0.96 & 2.26 \\
100 & - & 1.14 & 2.09 \\
100 & 0.64 & 1.14 & 2.75 \\
\hline
\end{tabular}

Quadro 15 - Efeitos de diferentes concentrações de aluminio no mosto ( 0,50 e $100 \mathrm{mg} / \mathrm{L}$ ) sobre o acúmulo de alumínio nas células, no transcorrer de 6 ciclos fermentativos, empregando-se a levedura Fleischmann e mosto semi-sintético com $21,7 \%$ de ART (pH 5,0). Dados em quadruplicata referentes ao experimento 1 . 


\begin{tabular}{|c|c|c|c|c|c|c|c|}
\hline 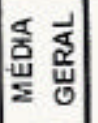 & & & స్ & & ले & & के \\
\hline \multirow{5}{*}{ 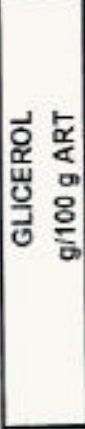 } & 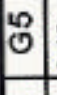 & 을 용 & 울 & 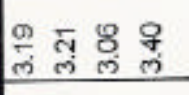 & 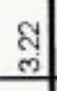 & 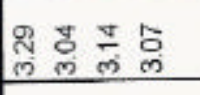 & $\frac{7}{m}$ \\
\hline & ن & गु & 8 & 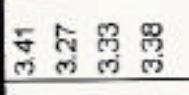 & लs & 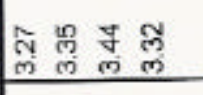 & $\begin{array}{c}0 \\
m \\
\end{array}$ \\
\hline & 0 & 恋 & बे & 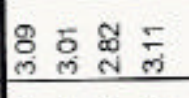 & हु & $\frac{m}{m}$ प & ग्ले \\
\hline & N & 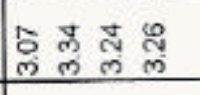 & ल्ल & 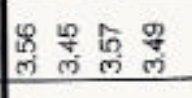 & लू & 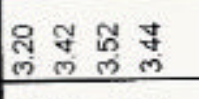 & के \\
\hline & $\overline{0}$ & 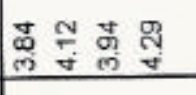 & $\begin{array}{l}8 \\
0 \\
\end{array}$ & 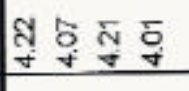 & $\frac{9}{7}$ & 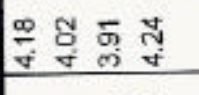 & $\begin{array}{l}\text { B } \\
\dot{v}\end{array}$ \\
\hline \multirow{6}{*}{ 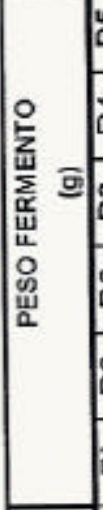 } & 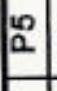 & $\begin{array}{lll}0 & 10 & 0 \\
0 & 0 & 0 \\
\infty & 0 & \infty \\
\end{array}$ & $\begin{array}{l}\text { gू } \\
\text { क } \\
\end{array}$ & 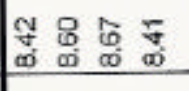 & 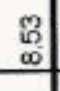 & 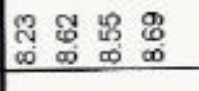 & $\begin{array}{c}\text { N } \\
\text { को }\end{array}$ \\
\hline & 品 & $\begin{array}{lll}\bar{n} & \mathbb{8} & \mathbb{8} \\
\infty & \infty & \infty \\
\end{array}$ & $\begin{array}{l}8 \\
\infty \\
\infty \\
\end{array}$ & 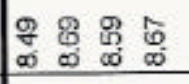 & - & 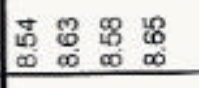 & $\begin{array}{l}8 \\
\infty \\
\end{array}$ \\
\hline & 2 & 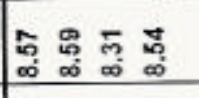 & : & 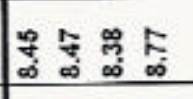 & 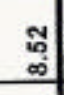 & 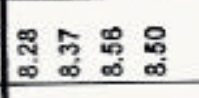 & 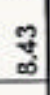 \\
\hline & 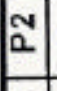 & 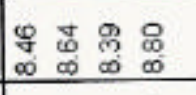 & $\begin{array}{l}10 \\
\infty \\
0\end{array}$ & 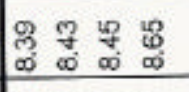 & $\underset{\infty}{+\infty}$ & 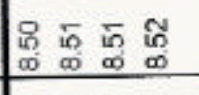 & $\begin{array}{l}50 \\
\infty \\
\end{array}$ \\
\hline & $\tilde{\alpha}$ & 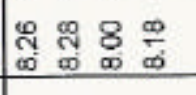 & $\stackrel{\infty}{\infty}$ & 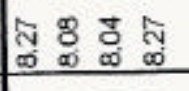 & $\frac{7}{-1}$ & $\underset{\infty}{\infty} \underset{\infty}{\infty} \underset{\infty}{\infty} \underset{\infty}{\infty}$ & శ్తి \\
\hline & $\bar{a}$ & 움윰웃 & 8 & 88.8 & $\stackrel{8}{0}$ & 8888 & 8 \\
\hline 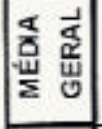 & & & $\frac{7}{8}$ & & के & & $\stackrel{\mathscr{Q}}{\mathscr{d}}$ \\
\hline \multirow{5}{*}{ 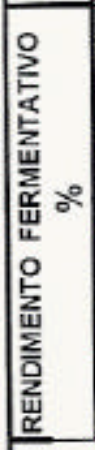 } & 2 & 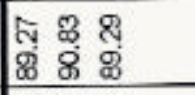 & $\begin{array}{l}8 \\
8 \\
8 \\
\end{array}$ & 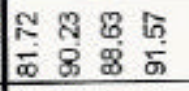 & $\frac{7}{8}$ & $\begin{array}{lll}8 & 8 \\
8 & 8 & 5 \\
8 & 8\end{array}$ & $\begin{array}{l}89 \\
8 \\
\end{array}$ \\
\hline & 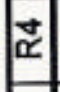 & $\begin{array}{lll}8 & 8 \\
8 & 5 \\
8 & 5 \\
\end{array}$ & $\begin{array}{l}8 \\
8 \\
\end{array}$ & 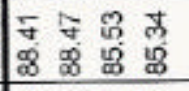 & 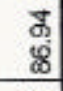 & 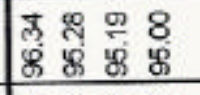 & $\begin{array}{l}8 \\
8 \\
\end{array}$ \\
\hline & $\approx$ & 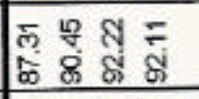 & $\begin{array}{l}8 \\
8 \\
8 \\
\end{array}$ & 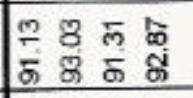 & $\begin{array}{l}8 \\
8\end{array}$ & 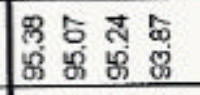 & $\begin{array}{l}\text { \& } \\
\text { पं }\end{array}$ \\
\hline & $\approx$ & 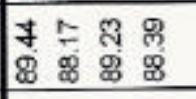 & $\begin{array}{l}\bar{\infty} \\
\dot{8} \\
\end{array}$ & \begin{tabular}{|l}
3 \\
8 \\
8
\end{tabular} & $\frac{9}{8}$ & 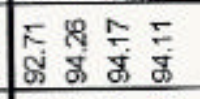 & $\begin{array}{l}5 \\
8 \\
8\end{array}$ \\
\hline & $\bar{x}$ & 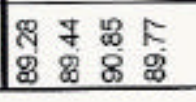 & $\begin{array}{l}\text { J } \\
8 \\
\end{array}$ & 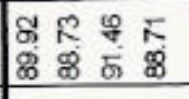 & $\begin{array}{l}8 \\
\infty \\
\infty\end{array}$ & 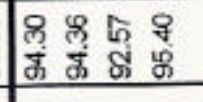 & $\frac{\varphi}{\dot{j}}$ \\
\hline \multicolumn{3}{|c|}{ 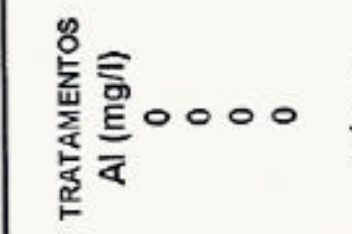 } & 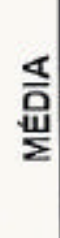 & 옹 & 言 & \multicolumn{2}{|l|}{ 응응응ㅇㅇ } \\
\hline
\end{tabular}

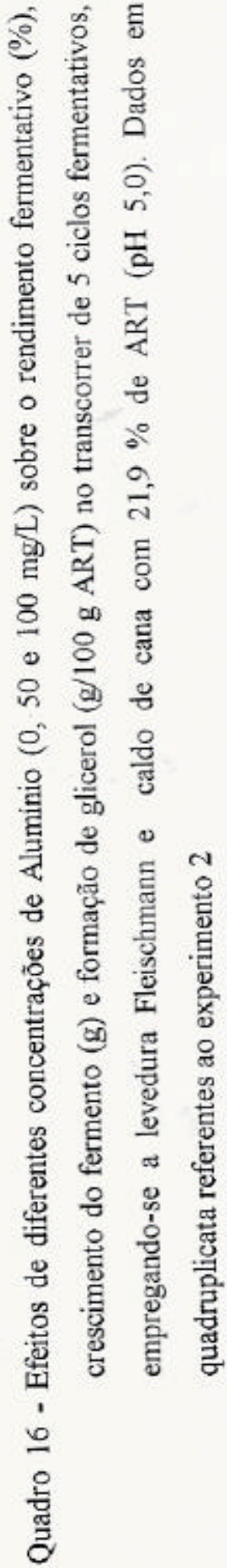




\begin{tabular}{|c|c|c|c|c|c|c|c|}
\hline \multirow{2}{*}{ 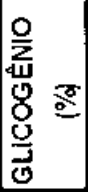 } & iz & $\dot{0} \stackrel{\circ}{\circ} \stackrel{0}{\circ}$ & $\frac{9}{6}$ & 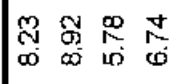 & $\stackrel{\text { พ }}{\sim}$ & 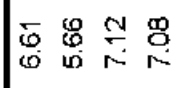 & \\
\hline & $\underline{\underline{z}}$ & 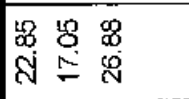 & ָָ & & : & 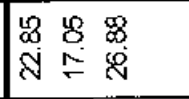 & \\
\hline \multirow{2}{*}{ 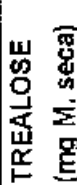 } & $|z|$ & 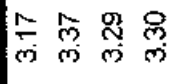 & "ู & 芯 & 导 & N্ণে ণ্ণ & \\
\hline & $\frac{\dot{0}}{\underline{\underline{z}}}$ & 동 & $\begin{array}{l}\stackrel{2}{2} \\
2\end{array}$ & 흥 & $\stackrel{?}{\stackrel{2}{0}}$ & 总 & \\
\hline \multirow{6}{*}{ 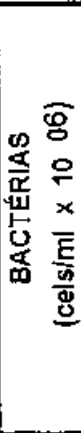 } & \begin{tabular}{|l|} 
\\
\end{tabular} & 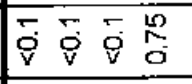 & 氶 & 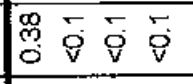 & $\frac{7}{0}$ & 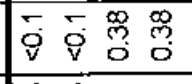 & $\mathcal{Z}$ \\
\hline & 他 & 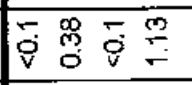 & $\stackrel{\text { ? }}{8}$ & 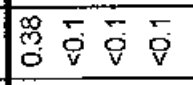 & $\underset{0}{0}$ & 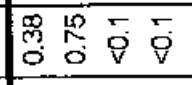 & - \\
\hline & 垈 & $\overline{\dot{\theta}} \overline{\dot{v}} \overline{\bar{q}} \overline{\bar{v}}$ & 0 & 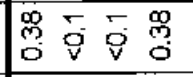 & స్ & 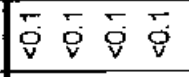 & 0 \\
\hline & 总 & $\overline{\dot{v}} \overline{\dot{v}} \overline{\dot{q}} \overline{\dot{v}}$ & 0 & 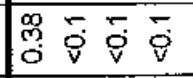 & $\frac{7}{0}$ & 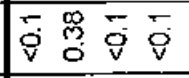 & 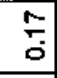 \\
\hline & $\overline{\mathrm{g}}$ & 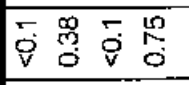 & \% & 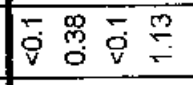 & 筞 & 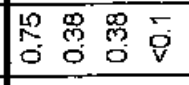 & 守 \\
\hline & $\overline{\mathrm{D}}$ & 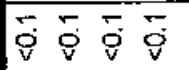 & 0 & 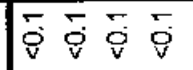 & $\circ$ & $\bar{\sigma}_{\bar{v}} \bar{o} \bar{v} \overline{\dot{p}} \bar{p}$ & o \\
\hline \multirow{5}{*}{ 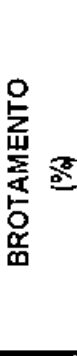 } & 总 & $m$ & $N$ & $m v$ & $m$ & Nom & N \\
\hline & \begin{tabular}{|l|}
$\begin{array}{c}\alpha \\
\alpha \\
0\end{array}$ \\
\end{tabular} & $0-00$ & 0 & $m-N o$ & $w$ & $m-m o$ & v \\
\hline & 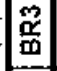 & I 000 & $\infty$ & $\mathrm{N} N \mathrm{NO}$ & $m$ & $10 \mathrm{~m}$ & $\nabla$ \\
\hline & 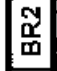 & $n m-n$ & N & $m \Delta \infty+$ & $m$ & त ल के & m \\
\hline & 商 & 10000 & $\infty$ & $N m+m$ & $m$ & $\begin{array}{ll}0 \mathrm{~m} \\
\mathrm{~m}\end{array}$ & $\forall$ \\
\hline \multirow{6}{*}{ 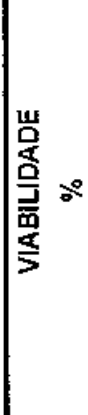 } & 19 & 莎 & 2 & (0) & む & 1988 & $\mathscr{8}$ \\
\hline & 5 & ऽ ஃ ஃ & \% & \% & 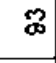 & Љ あ あ & \& \\
\hline & $\$$ & 落 & \$ & ஜஃ & 号 & \% \% & 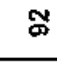 \\
\hline & $\$$ & $B$ & $\$$ & 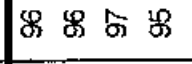 & $\mathscr{\circ}$ & 6. $88 \%$ & 5 \\
\hline & 5 & 85 & $\mathscr{8}$ & 18 5 8 5 & 5 & 8885 & $\infty$ \\
\hline & 5 & 88 & 思 & 8 & \% & 38 & g \\
\hline 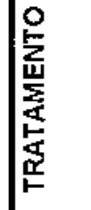 & E & & $\frac{\mathbb{4}}{\mathrm{i}}$ & & $\frac{\overleftarrow{6}}{\mathrm{u}}$ & & $\frac{\underline{x}}{\mathrm{U}}$ \\
\hline
\end{tabular}

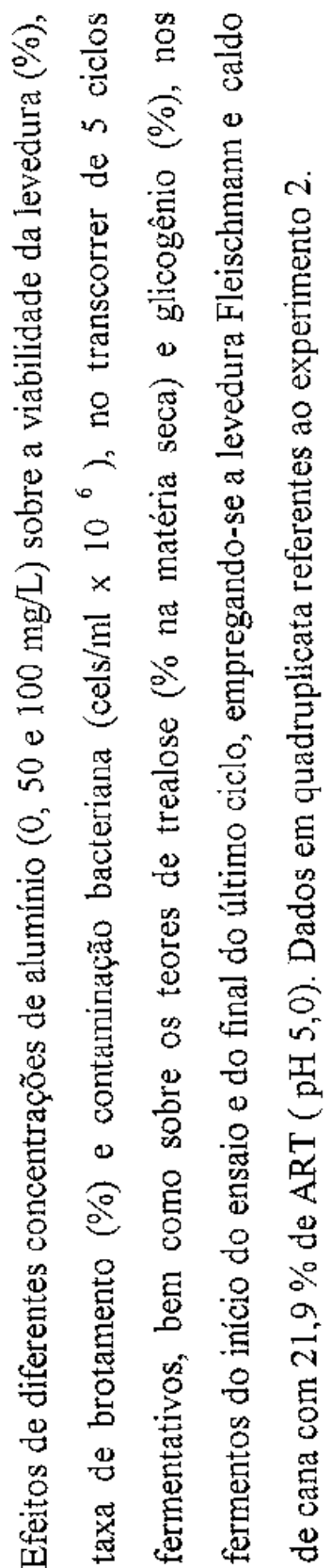




\begin{tabular}{|c|c|c|c|c|c|c|c|c|c|}
\hline \multirow{2}{*}{$\begin{array}{c}\text { TRATAMENTOS } \\
\text { mg Al/L }\end{array}$} & \multirow{2}{*}{$\begin{array}{l}\text { ciclo } \\
\left(\mathrm{N}^{\circ}\right)\end{array}$} & \multicolumn{8}{|c|}{ LIBERAÇĀO DE CO2 (g) } \\
\hline & & 1h & $2 \mathrm{~h}$ & $3 \mathrm{~h}$ & $4 \mathrm{~h}$ & $5 h$ & $6 \mathrm{~h}$ & $7 \mathrm{~h}$ & $20 \mathrm{~h}$ \\
\hline \multirow[t]{6}{*}{0} & $1^{\circ}$ & 0.84 & 1.73 & 2.75 & 3.65 & 4.31 & 4.83 & 5.19 & 6.32 \\
\hline & $2^{\circ}$ & 0.44 & 1.48 & 2.41 & 3.32 & 4.08 & 4.68 & 5.00 & 6.67 \\
\hline & $3^{\circ}$ & 0.42 & 1.71 & 2.49 & 3.44 & 4.14 & 4.78 & 5.01 & 5.85 \\
\hline & $4^{\circ}$ & 0.56 & 1.71 & 2.54 & 3.46 & 4.24 & 4.82 & 5.27 & 6.03 \\
\hline & $5^{3}$ & 0.56 & 1.29 & 2.21 & 3.09 & 3.63 & 4.18 & 4.64 & 5.87 \\
\hline & MÉDIA & 0.56 & 1.58 & 2.48 & 3.39 & 4.08 & 4.66 & 5.02 & 6.15 \\
\hline \multirow[t]{6}{*}{50} & $1^{\circ}$ & 0.84 & 1.60 & 2.53 & 3.36 & 3.97 & 4.47 & 4.80 & 6.32 \\
\hline & $2^{\circ}$ & 0.44 & 1.39 & 2.24 & 3.09 & 3.80 & 4.37 & 4.69 & 6.45 \\
\hline & $3^{\circ}$ & 0.42 & 1.71 & 2.49 & 3.44 & 4.14 & 4.78 & 5.01 & 5.85 \\
\hline & $4^{\circ}$ & 0.45 & 1.51 & 2.25 & 337 & 3.38 & 4.42 & 4.87 & 5.83 \\
\hline & $5^{\circ}$ & 0.56 & 1.29 & 2.21 & 3.09 & 3.63 & 4.18 & 4.64 & 5.87 \\
\hline & MÉDLA & 0.54 & 1.50 & 2.34 & 3.27 & 3.78 & 4.44 & 4.80 & 6.06 \\
\hline \multirow[t]{6}{*}{100} & $1^{\circ}$ & 0.65 & 1.38 & 2.32 & 3.15 & 3.76 & 4.25 & 4.58 & 6.30 \\
\hline & $2^{\circ}$ & 0.48 & 1.39 & 2.24 & 3.03 & 3.73 & 4.28 & 4.56 & 6.41 \\
\hline & $3^{\circ}$ & 0.24 & 1.29 & 2.00 & 2.88 & 3.55 & 4.17 & 4.40 & 5.72 \\
\hline & $4^{\circ}$ & 0.12 & 1,19 & 1.91 & 2.79 & 3.55 & 4.08 & 4.53 & 5.71 \\
\hline & $5^{\circ}$ & 0.47 & 1.39 & 2.44 & 3.42 & 4.03 & 4.61 & 5.11 & 6.09 \\
\hline & MÉDIA & 0.39 & 1.33 & 2.18 & 3.06 & 3.72 & 4.28 & 4.64 & 6.05 \\
\hline
\end{tabular}

Quadro 18 - Evolução da fermentação avaliada pela perda de peso $\left(\mathrm{g} \mathrm{CO}_{2}\right)$ a cada hora, para diferentes concentraçōes de aluminio $(0,50$ e $100 \mathrm{mg} / \mathrm{L})$ empregando-se a levedura Fleischmann e caldo de cana com 21,9\% de ART ( $\mathrm{pH} \mathrm{5,0).} \mathrm{Cada}$ dado representa a média de 4 reperiçōes, referentes ao experimento 2 . 


\begin{tabular}{|c|c|c|}
\hline \multirow{2}{*}{$\begin{array}{c}\text { TRATAMENTO } \\
\text { mg AI/L }\end{array}$} & \multicolumn{2}{|c|}{ mg Al/g MS } \\
\cline { 2 - 3 } & INICIAL & $\begin{array}{c}\mathbf{3}^{\mathbf{0}} \\
\text { CICLO }\end{array}$ \\
\hline 0 & 0.24 & 0.39 \\
0 & 0.25 & 0.35 \\
0 & 0.39 & 0.18 \\
0 & - & 0.38 \\
& & \\
MÉDIA & $\mathbf{0 . 2 9}$ & $\mathbf{0 . 3 3}$ \\
\hline 50 & 0.24 & 0.59 \\
50 & 0.25 & 0.65 \\
50 & 0.39 & 0.60 \\
50 & - & 0.70 \\
& & \\
MÉDIA & $\mathbf{0 . 2 9}$ & $\mathbf{0 . 6 4}$ \\
\hline 100 & 0.24 & 1.09 \\
100 & 0.25 & 1.18 \\
100 & 0.39 & 1.36 \\
100 & - & 1.27 \\
& & \\
MÉDIA & $\mathbf{0 . 2 9}$ & $\mathbf{1 . 2 3}$ \\
\hline
\end{tabular}

Quadro 19 - Efeitos de diferentes concentrações de alumínio $(0,50$ e 100 $\mathrm{mg} / \mathrm{L}$ ) sobre o acúmulo de alumínio nas células, no transcorrer de 5 ciclos fermentativos, empregando-se a levedura Fleischmann e caldo de cana com $21,90 \%$ de ART, (pH 5,0). Dados em quadruplicata referentes ao experimento 2 . 

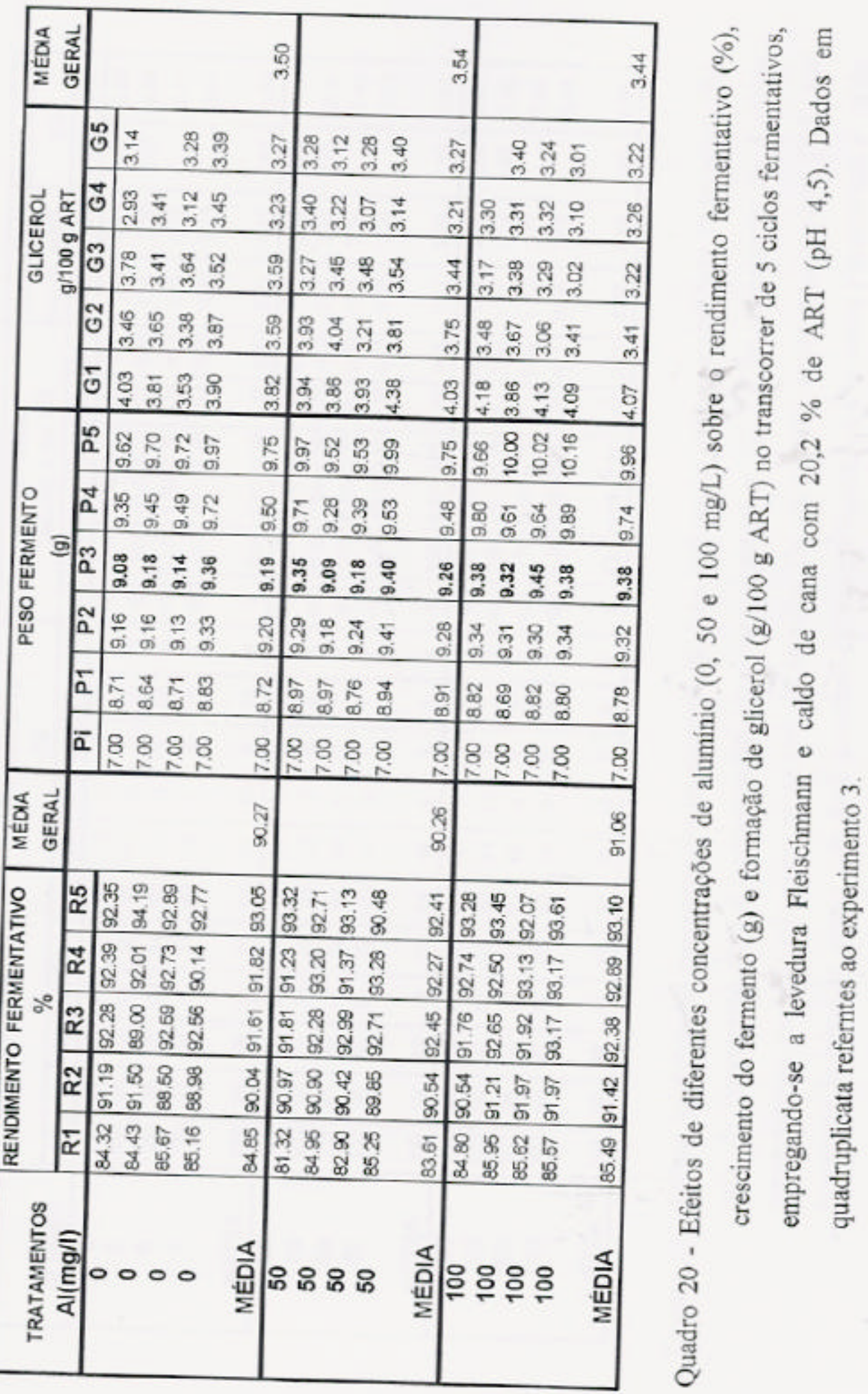


\begin{tabular}{|c|c|c|c|c|c|c|c|}
\hline \multirow{2}{*}{ 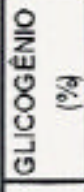 } & $\frac{i}{4}$ & 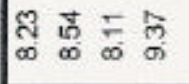 & 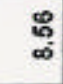 & 卷 券 & $\stackrel{\circ}{-}$ & $\begin{array}{llll}8 & 8 & 8 & 10 \\
6 & 5 & 6 & 6\end{array}$ & $\omega^{\circ}$ \\
\hline & $\underline{\underline{s}}$ & ल & $\underset{\sim}{\stackrel{\Xi}{~}}$ & هి & $\stackrel{\leftrightarrow}{*}$ & 尾 원 & $\stackrel{\mathscr{D}}{\sim}$ \\
\hline \multirow{2}{*}{ 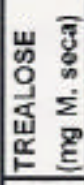 } & $\frac{z}{4}$ & ल & लू & $8 \bar{N} \bar{\sim}$ ल & సี & ర్ల స్ల స్ల & ন্ \\
\hline & $\underline{\underline{0}}$ & 운 홍 & สุ & 守 点 & ָุ & 운 몽 & 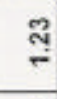 \\
\hline \multirow{6}{*}{ 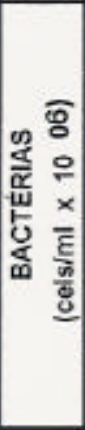 } & : & \% & $\bar{z}$ & 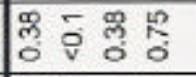 & సุ. & $\begin{array}{l}\text { i⿱ } \\
\text { o } \\
0\end{array}$ & స్ \\
\hline & 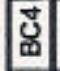 & $\bar{\nabla} \bar{\nabla} \stackrel{0}{\circ} \bar{g}$ & $\frac{1}{0}$ & $\mid \begin{array}{ll}R \\
R \\
0\end{array}$ & เ్ & एक & $=$ \\
\hline & 岛 & 禀点㣽㣽㣽 & $\begin{array}{l}0 \\
0 \\
0\end{array}$ & 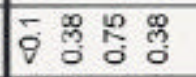 & స్ㅇㅇ & 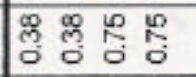 & 6 \\
\hline & ఫ్ & gू ơ & ஜ్ & 祒 & तु & 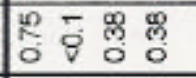 & $\bar{y}$ \\
\hline & 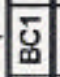 & 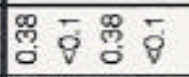 & व્: & $\begin{array}{lll} \\
\end{array}$ & to & 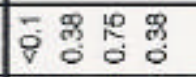 & 空 \\
\hline & $\bar{\square}$ & $\overline{8} \overline{8} \overline{8} \overline{8}$ & 0 & $\overline{8} \overline{8} \overline{8} \overline{8}$ & 0 & $\overline{\bar{\theta}} \bar{\phi} \bar{\phi} \overline{8}$ & 0 \\
\hline \multirow{5}{*}{ 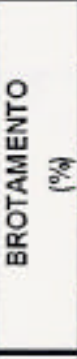 } & $\begin{array}{l} \\
\\
\end{array}$ & $N 00 N$ & $n$ & $N \infty$ & $\infty$ & NA & \\
\hline & 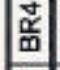 & 으 으 으 트 & $\simeq$ & ran & $\infty$ & $\infty \sim \infty \infty$ & $\infty$ \\
\hline & 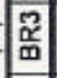 & $\sim \infty \sim \infty$ & $\infty$ & no & $\infty$ & $\infty \infty \infty n$ & $\infty$ \\
\hline & 茴 & 으 $\infty=\infty$ & 우 & a d a & $\infty$ & $=? \infty a$ & 은 \\
\hline & $\bar{\alpha}$ & $\simeq \cong 9 \pm$ & $=$ & Iฐ̃ & \pm & 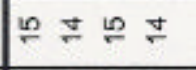 & $F$ \\
\hline \multirow{6}{*}{ 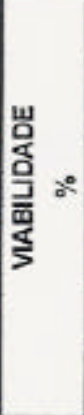 } & $\$$ & ஐ Б \& \& & Б & б \& \& & $\overline{5}$ & ஜ \& Б 8 & 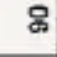 \\
\hline & $\$$ & ஆ க あ む & ष & ॠ ஃ \& & 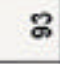 & ๙ ऊ \& ऊ & ชี \\
\hline & $\$$ & 8 के म 8 & $\mathscr{1}$ & ஜூ \& ภ హ & ๘ & ஜ के む \& & $\mathscr{8}$ \\
\hline & 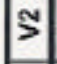 & 18888 & 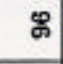 & F 8 & Б & \%思的 & $\tilde{\omega}$ \\
\hline & 5 & ৪ 8 ৪ & \% & 8 5 88 & ळ & $8 \% \& \&$ & 이 \\
\hline & 5 & 888 & \% & 8888 & 웅 & 8888 & 훙 \\
\hline 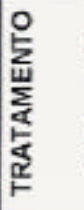 & 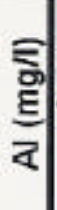 & $c$ & $\begin{array}{l}\text { 息 } \\
\text { 竞 }\end{array}$ & 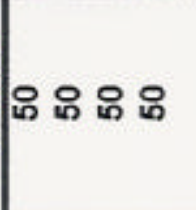 & 嗃 & 웅 & 은 \\
\hline
\end{tabular}




\begin{tabular}{|c|c|c|c|c|c|c|c|c|c|}
\hline \multirow{2}{*}{$\begin{array}{c}\text { TRATAMENTOS } \\
\text { mg Al/L }\end{array}$} & \multirow{2}{*}{$\begin{array}{l}\text { ciclo } \\
\left(\mathrm{N}^{\circ}\right)\end{array}$} & \multicolumn{8}{|c|}{ LIBERAÇĀO DE CO2(g) } \\
\hline & & Th & $2 \mathrm{~h}$ & $3 \mathbf{h}$ & 4h & $5 \mathrm{hh}$ & $6 h$ & $7 \mathrm{~h}$ & $20 \mathrm{~h}$ \\
\hline \multirow[t]{6}{*}{0} & $1^{\circ}$ & 0.68 & 1.47 & 2.61 & 3.17 & 4.14 & 4.68 & 5.11 & 5.66 \\
\hline & $2^{\mathbf{0}}$ & 0.59 & 1.56 & 2.56 & 3.40 & 4,18 & 4.75 & 5.20 & 5.95 \\
\hline & $3^{a}$ & 0.57 & 1.66 & 2.69 & 3.57 & 4.28 & 4.38 & 5.39 & 6.07 \\
\hline & $4^{\circ}$ & 0.36 & 1.46 & 2.43 & 3.45 & 4.22 & $\angle 83$ & 5.26 & 5.86 \\
\hline & $5^{a}$ & 0.40 & 1.37 & 2.44 & 3.45 & 4. 26 & 4.98 & 5.40 & 6.29 \\
\hline & MÉDIA & 0.52 & 1.50 & 2.55 & 3.41 & 4.22 & 4.72 & 5.27 & 5.97 \\
\hline \multirow[t]{6}{*}{50} & $1^{\circ}$ & 0.66 & 1.40 & 2.21 & 2.99 & 3.93 & 4.46 & 492 & 5.62 \\
\hline & $2^{0}$ & 0.52 & 1.33 & 2.17 & 3.14 & 3.59 & 4.12 & 4.53 & 5.89 \\
\hline & $3^{n}$ & 0.51 & 1.41 & 2.30 & 3.06 & 3,67 & 4.22 & 4.73 & 5.98 \\
\hline & $4^{\circ}$ & 0.50 & 1.48 & 2.32 & 3.18 & 3.83 & 4.38 & 4.82 & 5.89 \\
\hline & $5^{\circ}$ & 0.38 & 1.27 & 2.23 & 3.13 & 3.85 & 4.51 & 494 & 5.98 \\
\hline & MÉDA & 0.51 & 1.38 & 2.25 & 3.10 & 3.77 & 4.34 & 4.79 & 5.87 \\
\hline \multirow[t]{6}{*}{100} & $1^{\circ}$ & 0.29 & 1.23 & 2.03 & 2.78 & 3.67 & 4.17 & 4.64 & 5.65 \\
\hline & $2^{\circ}$ & 0.37 & 4.11 & 1.87 & 2.53 & 3.20 & 3.67 & 4.10 & 5.87 \\
\hline & $3^{\circ}$ & 0.40 & 1.29 & 2.10 & 2.83 & 3.37 & 3.92 & 4.42 & 6.01 \\
\hline & $4^{\circ}$ & 0.70 & 1.65 & 2.42 & 3.26 & 3.86 & $<.38$ & 4.79 & 6.00 \\
\hline & $5^{\circ}$ & 0.34 & 1.21 & 2.12 & 3.21 & 3,65 & $\angle .28$ & 4.70 & 6.01 \\
\hline & MÉLUA & 0.42 & 1.30 & 2.11 & 2.92 & 3.55 & 4.08 & 4.53 & 5.91 \\
\hline
\end{tabular}

Quadro 22 - Evolução da fermentação avaliada pela perda de peso $\left(\mathrm{g} \mathrm{CO}_{2}\right)$ a cada hora, para diferentes concentrações de alumínio $(0,50$ e $100 \mathrm{mg} / \mathrm{L})$ empregando-se a levedura Fleischmann e caldo de cana com $20,2 \%$ de ART ( $\mathrm{pH} 4,5$ ). Cada dado representa a média de 4 repetições, referentes ao experimento 3 . 


\begin{tabular}{|c|c|c|c|}
\hline \multirow{2}{*}{$\begin{array}{c}\text { TRATAMENTO } \\
\text { Al mg/L }\end{array}$} & \multicolumn{3}{|c|}{ mg Al/ g MS } \\
\cline { 2 - 4 } & INICIAL. & $\begin{array}{c}\mathbf{3}^{\mathbf{0}} \\
\text { ciclo }\end{array}$ & $\begin{array}{c}\mathbf{5}^{\mathbf{0}} \\
\text { ciclo }\end{array}$ \\
\hline 0 & 0 & 0.22 & 0.20 \\
0 & 0 & 0.22 & 0.17 \\
0 & 0.23 & 0.21 & 0.26 \\
0 & - & 0.30 & 0.25 \\
MÉDIA & 0.08 & $\mathbf{0 . 2 4}$ & $\mathbf{0 . 2 2}$ \\
\hline 50 & 0 & 0.32 & 0.69 \\
50 & 0 & 0.42 & 0.74 \\
50 & 0.23 & 0.44 & 0.45 \\
50 & - & 0.49 & 0.59 \\
& & & \\
MÉDIA & $\mathbf{0 . 0 8}$ & $\mathbf{0 . 4 2}$ & $\mathbf{0 . 6 2}$ \\
\hline 100 & 0 & 0.65 & 0.82 \\
100 & 0 & 0.57 & 0.76 \\
100 & 0.23 & 0.65 & 1.57 \\
100 & - & 0.57 & 1.46 \\
& & & \\
MÉDIA & $\mathbf{0 . 0 8}$ & $\mathbf{0 . 6 1}$ & $\mathbf{1 . 1 5}$ \\
\hline
\end{tabular}

Quadro 23 - Efeitos de diferentes concentrações de alumínio $(0,50$ e 100 $\mathrm{mg} / \mathrm{L}$ ) sobre o acúmulo de alumínio nas células, no transcorrer de 5 ciclos fermentativos, empregando-se a levedura Fleischmann e caldo de cana com $20,2 \%$ de ART ( $\mathrm{pH} 4,5$ ). Dados em quadruplicata referentes ao experimento 3. 


\begin{tabular}{|c|c|c|c|c|c|c|c|c|c|}
\hline 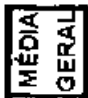 & & & $\infty$ & & \& & & 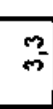 & & i \\
\hline \multirow{5}{*}{ 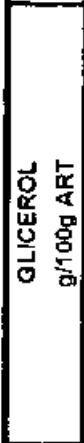 } & 10 & ले ले & क् & 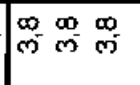 & - & $\stackrel{\infty}{\infty}$ & $m$ & $\bar{m}$ के के & $\bar{m}$ \\
\hline & ज & क्ष & $\stackrel{\infty}{\infty}$ & 응응응 & 웅 & $\mathscr{m}$ & $\stackrel{0}{m}$ & $\bar{m} \bar{m}$ & $\Rightarrow$ \\
\hline & 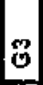 & men & $m_{-\infty}^{n}$ & 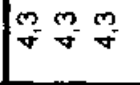 & $\stackrel{m}{+}$ & 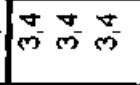 & $\vec{s}$ & $a \stackrel{a}{a} \stackrel{a}{i}$ & $\stackrel{9}{N}$ \\
\hline & $\tilde{~}$ & $\bar{ल} \overline{~ ल े ~}$ & के & 웅 & 움 & ले ले & 品 & $\mathbb{N}_{N}^{\infty} \stackrel{\infty}{\sim} \stackrel{\infty}{N}$ & $\stackrel{\infty}{N}$ \\
\hline & б & m & mp & $\stackrel{\circ}{m} \stackrel{\infty}{m} \stackrel{0}{m}$ & $\stackrel{0}{\infty}$ & $\underset{m}{N} \underset{m}{N}$ & $\tilde{m}$ & On & 品 \\
\hline \multirow{6}{*}{ 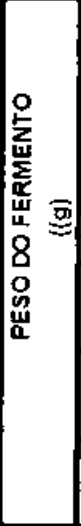 } & 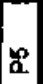 & $\omega_{\infty}^{\infty}=\frac{\infty}{\infty}$ & 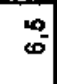 & 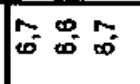 & (1) & $\approx=\infty$ & $=$ & $\approx \cong \cong$ & 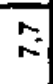 \\
\hline & 茄 & war & $\stackrel{\infty}{\infty}$ & कor & 每 & $\begin{array}{l}\forall=0 \\
m=0\end{array}$ & 5 & 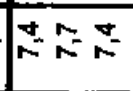 & 2 \\
\hline & n & 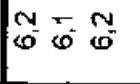 & $\bar{\infty}$ & 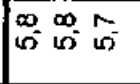 & $\begin{array}{ll}\infty \\
\infty \\
\infty\end{array}$ & 里 & $\stackrel{2}{\sim}$ & $\frac{\pi}{n}$ & 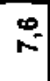 \\
\hline & a & $\begin{array}{lll}\nabla & 9 \\
0 & 0 & 0 \\
0\end{array}$ & $\infty$ & $=0$ & $\begin{array}{l}0 \\
0 \\
\infty\end{array}$ & $\stackrel{\infty}{N} \stackrel{\infty}{N}$ & $\stackrel{\infty}{\infty}$ & $\infty=\frac{0}{\infty}$ & $\stackrel{\infty}{N}$ \\
\hline & $\overline{\mathbf{\alpha}}$ & $0 \%$ & o & 量 $=0$ & 웃 & $\approx=-5$ & జ్ & $\frac{N}{\infty}=\frac{2}{N}$ & $\stackrel{9}{\sim}$ \\
\hline & $\bar{a}$ & 웃웅요 & 용 & 온용용 & 은 & 운온용 & 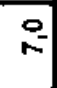 & 은운용 & 용 \\
\hline 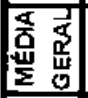 & & & $\begin{array}{l}9 \\
0\end{array}$ & & ה̦ & & 恶 & & $\begin{array}{l}\circ \\
8 \\
\end{array}$ \\
\hline \multirow{5}{*}{ 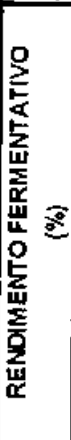 } & 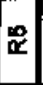 & $=\frac{1}{8}$ & $=$ & $\begin{array}{l}0 \\
0 \\
0\end{array}$ & 8 & 勿음 & 高 & क人 & ळ. \\
\hline & 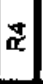 & 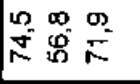 & $\begin{array}{l}1 \\
0 \\
0\end{array}$ & 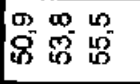 & : & 品禹 & 勇 & 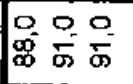 & 옹 \\
\hline & 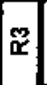 & 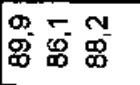 & ڤ్ & 임 & : & 孚 & $\begin{array}{l}\infty \\
\infty \\
\infty \\
\infty\end{array}$ & $\frac{0}{6} \frac{-1}{6}$ & $\begin{array}{l}\infty \\
5 \\
5\end{array}$ \\
\hline & $\widetilde{\alpha}$ & 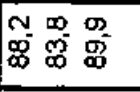 & $\begin{array}{l}3 \\
0 \\
\infty\end{array}$ & 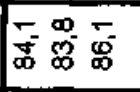 & 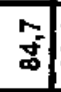 & $\begin{array}{lll}6 & 0 \\
8 & 8 & 8 \\
8\end{array}$ & 용 & 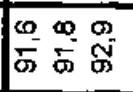 & $\bar{\Phi}$ \\
\hline & $\bar{\alpha}$ & 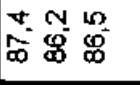 & 今 & 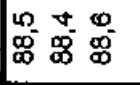 & 垈 & $\begin{array}{l}0 \\
0 \\
0 \\
0 \\
0\end{array}$ & 离 & 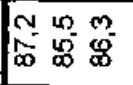 & $\begin{array}{l}m \\
\vdots \\
\infty\end{array}$ \\
\hline 点 & & $\begin{array}{l}0 \\
0\end{array}$ & $\frac{a}{\bar{a}}$ & 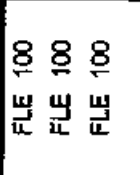 & 章 & 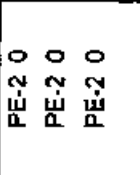 & $\begin{array}{l}\frac{a}{5} \\
\frac{\mathrm{m}}{2}\end{array}$ & 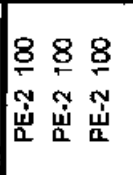 & $\begin{array}{l}\text { 줄 } \\
\frac{\mathbf{w}}{\Sigma}\end{array}$ \\
\hline
\end{tabular}

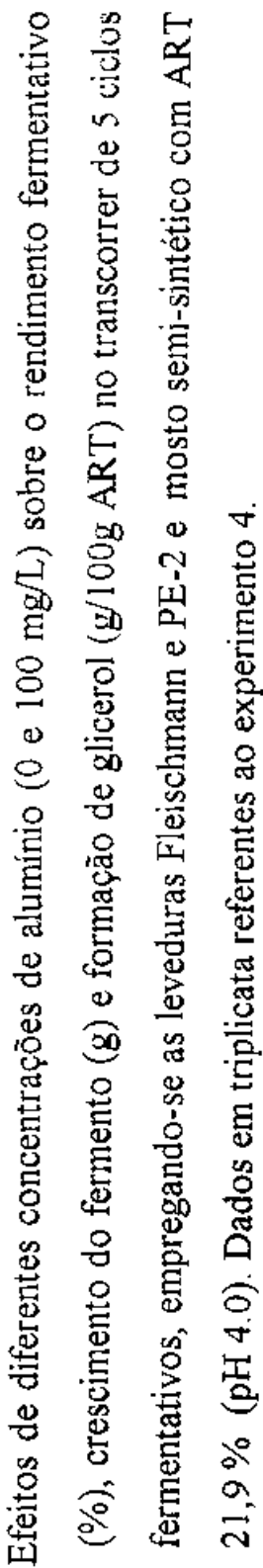



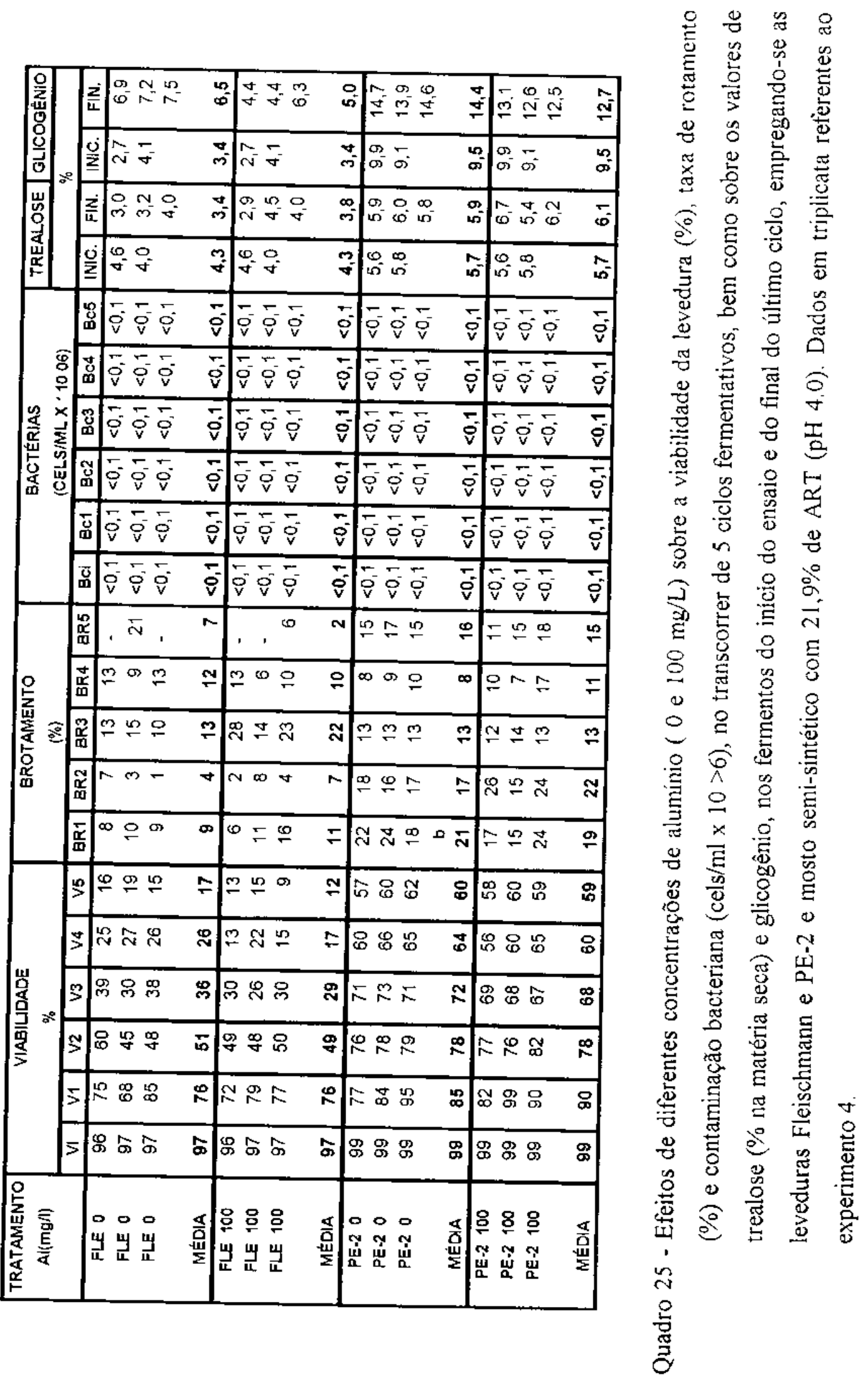


\begin{tabular}{|c|c|c|c|c|c|c|c|c|c|}
\hline \multirow{2}{*}{$\begin{array}{l}\text { TRATAMENTOS } \\
\text { Al }(\mathrm{mg} / \mathrm{l})\end{array}$} & \multirow{2}{*}{$\begin{array}{c}\text { CICLO } \\
\left(N^{\circ}\right)\end{array}$} & \multicolumn{8}{|c|}{ LIBERAÇAO DE C02 (g) } \\
\hline & & 1h & $2 h$ & $3 \mathrm{~h}$ & $4 h$ & $5 h$ & $6 h$ & $7 \mathrm{~h}$ & $20 \mathrm{~h}$ \\
\hline \multirow[t]{6}{*}{ FLE 0} & $1^{\circ}$ & 0,03 & 0,56 & 1,65 & 2,96 & 3,96 & 4.74 & 5,37 & 6.23 \\
\hline & $2^{\circ}$ & 0,08 & 1,00 & 2.16 & 2.95 & 3.80 & 4.52 & 5,14 & 6,23 \\
\hline & $3^{\circ}$ & 0,06 & 0,70 & 1,86 & 2,43 & 3,20 & 3,81 & 4,32 & 6,06 \\
\hline & $4^{\circ}$ & 0,03 & 0,30 & 1,04 & 1,28 & 1,74 & 2.23 & 2,61 & 4,65 \\
\hline & $5^{\circ}$ & 0,08 & 0,25 & 0,58 & 1,03 & 1,35 & $1, \pi$ & 2,16 & 4,17 \\
\hline & MÉDIA & 0,06 & 0,56 & 1,46 & 2,13 & 2,81 & 3,41 & 3,92 & 5,47 \\
\hline \multirow[t]{6}{*}{ FLE 100} & $1^{\circ}$ & 0,03 & 0,74 & 1,78 & 2,95 & 3,81 & 4,52 & 5,11 & 6,22 \\
\hline & $2^{\circ}$ & 0,06 & 1,15 & 2,26 & 2,97 & 3,72 & 4,33 & 4,85 & 6,06 \\
\hline & $3^{0}$ & 0.02 & 0,53 & 1,59 & 2,08 & 2,76 & 3.28 & 3,74 & 5,54 \\
\hline & $4^{\circ}$ & 0,05 & 0,25 & 0,91 & 1,11 & 1.50 & 1,92 & 2,23 & 3,85 \\
\hline & $5^{\circ}$ & 0.05 & 0,17 & 0,40 & 0.70 & 0,97 & 1,39 & 1,63 & 3,65 \\
\hline & ME்DIA & 0,04 & 0,57 & 1,39 & 1,96 & 2,55 & 3,09 & 3,51 & 5,06 \\
\hline \multirow[t]{6}{*}{ PE-2 0} & $1^{\circ}$ & 0,04 & 0.25 & 1,63 & 2,87 & 3,82 & 4,66 & 5,29 & 5,97 \\
\hline & $2^{\circ}$ & 0,19 & 1,21 & 3,39 & 3.20 & 4,09 & 4,52 & 5,44 & 6,31 \\
\hline & $3^{\circ}$ & 0,11 & 1,07 & 2,50 & 3,16 & 4,05 & $4, \pi 7$ & 5,31 & 6,23 \\
\hline & $4^{\circ}$ & 0.10 & 0,88 & 2,29 & 2.69 & 3,43 & 4.13 & 4,61 & 6,08 \\
\hline & $5^{\circ}$ & 0,19 & 1,02 & 1,96 & 2,92 & 3.55 & 4.27 & 4,91 & 6,24 \\
\hline & MÉDIA & 0,13 & 0,89 & 2,35 & 2,97 & 3,79 & 4,47 & 5,11 & 6,17 \\
\hline \multirow[t]{6}{*}{ PE-2 100} & $1^{0}$ & 0.04 & 0,78 & 1,79 & 2,90 & 3,79 & 4,60 & 5,25 & 6,07 \\
\hline & $2^{\circ}$ & 0,20 & 1.26 & 2,69 & 3,13 & 3.99 & 5,05 & 5,35 & 6,36 \\
\hline & $3^{\circ}$ & 0,06 & 0,92 & 2,32 & 2,99 & 3,89 & 4,62 & 5,20 & 6,33 \\
\hline & $4^{0}$ & 0,17 & 1,07 & 2,46 & 2,81 & 3,56 & 4.27 & 4,61 & 6,08 \\
\hline & $5^{0}$ & 0,23 & 1,14 & 2,12 & 3,14 & 3,78 & 4,49 & 5.05 & 6,32 \\
\hline & MĖDIA & 0,14 & 1,03 & 2,28 & 2,99 & 3,80 & 4,61 & 5,09 & 6,23 \\
\hline
\end{tabular}

Quadro 26 - Evolução da fermentação avaliada pela perda de peso ( $\mathrm{g} \mathrm{CO} 2$ ) a cada hora, para diferentes concentraçōes de alumínio ( 0 e $100 \mathrm{mg} / \mathrm{L}$ ) empregando-se as leveduras Fleischmann PE-2 e mosto semi-sintético com $21,9 \%$ de ART (pH 4.0). Cada dado representa a média de 3 repetições, referentes ao experimento 4 . 


\begin{tabular}{|c|c|c|c|}
\hline \multirow[t]{2}{*}{$\begin{array}{l}\text { TRATAMENTO } \\
\text { Al (mg/l) }\end{array}$} & \multicolumn{3}{|c|}{$\mathrm{mgAl} / \mathrm{gM}{ }_{n} \mathrm{~S}}$. \\
\hline & INICIAL & $3^{\circ}$ ciclo & $5^{\circ}$ ciclo \\
\hline FLE 0 & 0,43 & 0,59 & 0,84 \\
\hline FLE 0 & 0,46 & 0,70 & 0,82 \\
\hline FLE 0 & & 0,62 & 0,78 \\
\hline MÉDIA & 0,45 & 0,64 & 0,81 \\
\hline FLE 100 & 0,43 & 3,81 & 4,04 \\
\hline FLE 100 & 0,46 & 4,16 & 4,36 \\
\hline FLE 100 & & 4,24 & 4,25 \\
\hline MÉDIA & 0,45 & 4,07 & 4,22 \\
\hline PE-2 0 & 0,49 & 0,70 & 0,86 \\
\hline PE-2 0 & 0,55 & 0,65 & 0,66 \\
\hline PE-2 0 & & 0,57 & 0,69 \\
\hline MÉDIA & 0,52 & 0,64 & 0,74 \\
\hline PE- 100 & 0,49 & 2,21 & 2,35 \\
\hline PE- 100 & 0,55 & 2,10 & 2,47 \\
\hline PE- 100 & & 2,26 & 2,43 \\
\hline MÉDIA & 0,52 & 2,19 & 2,42 \\
\hline
\end{tabular}

Quadro 27 - Efeitos de diferentes concentrações de aluminio (0 e $100 \mathrm{mg} / \mathrm{L}$ ) sobre o acúmulo de alumínio nas células, no transcorrer de 5 ciclos fermentativos, empregando-se as leveduras Fleischmann e PE-2 e mosto semi-sintético com $21,9 \%$ de ART ( $\mathrm{pH} 4.0$ ). Dados em triplicata referentes ao experimento 4. 
ANEXO B: Análise Estatística 
Experimento 1

Tabela 1. Rendimento fermentativo (\%).

\begin{tabular}{ccccccc}
\hline \hline Tratamentos & \multicolumn{6}{c}{ CICLOS FERMENTATIVOS } \\
\cline { 2 - 6 }$($ mg Al/L) & $1^{\circ}$ & $2^{\circ}$ & $3^{\circ}$ & $4^{\circ}$ & $5^{\circ}$ & $6^{\circ}$ \\
\hline \hline Fle 0 & $87,19 \mathrm{Aa}$ & $89,10 \mathrm{Aa}$ & $90,02 \mathrm{Aa}$ & $90,54 \mathrm{Aa}$ & $89,71 \mathrm{Aa}$ & $89,71 \mathrm{Aa}$ \\
Fle 50 & $85,79 \mathrm{Aa}$ & $90,25 \mathrm{Aab}$ & $91,05 \mathrm{Aab}$ & $89,74 \mathrm{Aa}$ & $89,83 \mathrm{Aa}$ & $89,56 \mathrm{Aa}$ \\
Fle 100 & $86,04 \mathrm{Aa}$ & $91,46 \mathrm{Ab}$ & $91,63 \mathrm{Ab}$ & $90,89 \mathrm{Aa}$ & $91,80 \mathrm{Aa}$ & $89,88 \mathrm{Aa}$ \\
\multicolumn{6}{c}{ COEFICIENTE DE VARIAÇÃO: 0,98 } \\
\hline As médias seguidas pelas mesmas letras (maiúsculas e minúsculas) não diferem \\
entre si dentro de uma mesma coluna, de acordo c om o teste de Tukey a 1 e 5\% de \\
significância.
\end{tabular}

Tabela 2. Peso do fermento (g).

\begin{tabular}{ccccccc}
\hline \hline \multirow{6}{*}{$\begin{array}{c}\text { Tratamentos } \\
\text { (mg Al/L) })\end{array}$} & $1^{\circ}$ & $2^{\circ}$ & $3^{\circ}$ & $4^{\circ}$ & $5^{\circ}$ & $6^{\circ}$ \\
\cline { 2 - 6 } Fle 0 & $9,34 \mathrm{Aa}$ & $9,85 \mathrm{Aa}$ & $10,03 \mathrm{Aa}$ & $9,52 \mathrm{Aa}$ & $9,86 \mathrm{Aa}$ & $9,98 \mathrm{Aa}$ \\
Fle 50 & $9,24 \mathrm{Aa}$ & $9,59 \mathrm{Aa}$ & $9,75 \mathrm{Aab}$ & $9,25 \mathrm{Aa}$ & $9,62 \mathrm{Aa}$ & $9,58 \mathrm{Aa}$ \\
Fle 100 & $9,16 \mathrm{Aa}$ & $9,50 \mathrm{Aa}$ & $9,56 \mathrm{Ab}$ & $9,41 \mathrm{Aa}$ & $9,62 \mathrm{Aa}$ & $9,54 \mathrm{Aa}$ \\
\multicolumn{6}{c}{ COEFICIENTE DE VARIAÇÃO: 1,76} \\
\hline \hline
\end{tabular}

As médias seguidas pelas mesmas letras (maiúsculas e minúsculas) não diferem entre si dentro de uma mesma coluna, de acordo com o teste de Tukey a 1 e $5 \%$ de significância. 
Tabela 3. Glicerol (g/100 g ART).

\begin{tabular}{|c|c|c|c|c|c|c|}
\hline \multirow{2}{*}{$\begin{array}{c}\text { Tratamentos } \\
\text { (mg Al/L) }\end{array}$} & \multicolumn{6}{|c|}{ CICLOS FERMENTATIVOS } \\
\hline & $1^{\circ}$ & $2^{\circ}$ & $3^{\circ}$ & $4^{\circ}$ & $5^{\circ}$ & $6^{\circ}$ \\
\hline Fle 0 & $2,45 \mathrm{Aa}$ & $2,13 \mathrm{Aa}$ & $2,65 \mathrm{Aa}$ & $2,79 \mathrm{Aa}$ & $2,92 \mathrm{Aa}$ & $2,20 \mathrm{Aa}$ \\
\hline Fle 50 & $2,35 \mathrm{Aa}$ & $2,16 \mathrm{Aa}$ & $2,60 \mathrm{Aa}$ & $3,05 \mathrm{Aa}$ & $3,02 \mathrm{Aa}$ & $2,25 \mathrm{Aa}$ \\
\hline Fle 100 & $2,51 \mathrm{Aa}$ & $2,36 \mathrm{Aa}$ & $2,48 \mathrm{Aa}$ & $3,28 \mathrm{Aa}$ & $3,17 \mathrm{Aa}$ & $2,29 \mathrm{Aa}$ \\
\hline \multicolumn{7}{|c|}{ COEFICIENTE DE VARIAÇÃO: 8,66 } \\
\hline
\end{tabular}

Tabela 4. Viabilidade (\%).

\begin{tabular}{ccccccc}
\hline \hline \multirow{7}{*}{$\begin{array}{c}\text { Tratamentos } \\
(\mathrm{mg} \mathrm{Al} / \mathrm{L})\end{array}$} & $1^{\circ}$ & $2^{\circ}$ & $3^{\circ}$ & $4^{\circ}$ & $5^{\circ}$ & $6^{\circ}$ \\
\cline { 2 - 6 } Fle 0 & $99 \mathrm{Aa}$ & $93 \mathrm{Aa}$ & $90 \mathrm{Aa}$ & $88 \mathrm{Aab}$ & $85 \mathrm{Aa}$ & $76 \mathrm{Aa}$ \\
Fle 50 & $99 \mathrm{Aa}$ & $94 \mathrm{Aa}$ & $91 \mathrm{Aa}$ & $89 \mathrm{Aa}$ & $86 \mathrm{Aa}$ & $80 \mathrm{Bb}$ \\
Fle 100 & $99 \mathrm{Aa}$ & $93 \mathrm{Aa}$ & $90 \mathrm{Aa}$ & $85 \mathrm{Ab}$ & $85 \mathrm{Aa}$ & $77 \mathrm{ABab}$ \\
\multicolumn{7}{c}{ COEFICIENTE DE VARIAÇÃO: 1,61} \\
\hline \hline
\end{tabular}

As médias seguidas pelas mesmas letras (maiúsculas e minúsculas) não diferem entre si dentro de uma mesma coluna, de acordo com o teste de Tukey a 1 e $5 \%$ de significância. 
Tabela 5. Teor inicial e final de trealose (\% MS) e glicogênio (\% MS).

\begin{tabular}{ccc}
\hline $\begin{array}{c}\text { Tratamentos } \\
(\mathrm{mg} \mathrm{Al} / \mathrm{L})\end{array}$ & $\begin{array}{c}\text { Trealose } \\
(\% \mathrm{MS})\end{array}$ & $\begin{array}{c}\text { Glicogênio } \\
(\% \mathrm{MS})\end{array}$ \\
\hline \hline Fle 0 & $2,12 \mathrm{Aa}$ & $9,79 \mathrm{Bb}$ \\
Fle 50 & $1,75 \mathrm{Aa}$ & $7,54 \mathrm{Aa}$ \\
Fle 100 & $1,65 \mathrm{Aa}$ & $10,18 \mathrm{Cc}$ \\
& COEFICIENTE DE VARIAÇÃO: 14,33 \\
\hline
\end{tabular}

As médias seguidas pelas mesmas letras (maiúsculas e minúsculas) não diferem entre si dentro de uma mesma coluna, de acordo com o teste de Tukey a 1 e $5 \%$ de significância.

Experimento 2

Tabela 6. Rendimento fermentativo (\%).

\begin{tabular}{cccccc}
\hline \hline Tratamentos & \multicolumn{5}{c}{ CICLOS FERMENTATIVOS } \\
\cline { 2 - 6 }$(\mathrm{mg} \mathrm{Al} / \mathrm{L})$ & $1^{\circ}$ & $2^{\circ}$ & $3^{\circ}$ & $4^{\circ}$ & $5^{\circ}$ \\
\hline \hline Fle 0 & $89,84 \mathrm{Aa}$ & $88,81 \mathrm{Aa}$ & $90,53 \mathrm{Aa}$ & $90,99 \mathrm{Aba}$ & $89,80 \mathrm{Aa}$ \\
Fle 50 & $88,99 \mathrm{Aa}$ & $90,19 \mathrm{Aa}$ & $92,08 \mathrm{Aa}$ & $86,94 \mathrm{Ab}$ & $90,44 \mathrm{Aa}$ \\
Fle 100 & $90,39 \mathrm{Aa}$ & $90,06 \mathrm{Aa}$ & $91,09 \mathrm{Aa}$ & $91,76 \mathrm{Ba}$ & $91,54 \mathrm{Aa}$ \\
\multicolumn{4}{c}{ COEFICIENTE DE VARIAÇÃO: 1,25} \\
\end{tabular}

As médias seguidas pelas mesmas letras (maiúsculas e minúsculas) não diferem entre si dentro de uma mesma coluna, de acordo com o teste de Tukey a 1 e $5 \%$ de significância. 
Tabela 7. Peso do fermento (g).

\begin{tabular}{cccccc}
\hline \hline \multirow{2}{*}{$\begin{array}{c}\text { Tratamentos } \\
\text { (mg Al/L) }\end{array}$} & $1^{\circ}$ & $2^{\circ}$ & $3^{\circ}$ & $4^{\circ}$ & $5^{\circ}$ \\
\cline { 2 - 6 } Fle 0 & $8,18 \mathrm{Aa}$ & $8,57 \mathrm{Aa}$ & $8,50 \mathrm{Aa}$ & $8,68 \mathrm{Aa}$ & $8,49 \mathrm{Aa}$ \\
Fle 50 & $8,17 \mathrm{Aa}$ & $8,48 \mathrm{Aa}$ & $8,52 \mathrm{Aa}$ & $8,61 \mathrm{Aa}$ & $8,53 \mathrm{Aa}$ \\
Fle 100 & $8,20 \mathrm{Aa}$ & $8,51 \mathrm{Aa}$ & $8,43 \mathrm{Aa}$ & $8,60 \mathrm{Aa}$ & $8,52 \mathrm{Aa}$ \\
\multicolumn{4}{c}{ COEFICIENTE DE VARIAÇÃO: 1,76} \\
\hline
\end{tabular}

As médias seguidas pelas mesmas letras (maiúsculas e minúsculas) não diferem entre si dentro de uma mesma coluna, de acordo com o teste de Tukey a 1 e $5 \%$ de significância.

Tabela 8. Glicerol (g/100 g ART).

\begin{tabular}{cccccc}
\hline \hline Tratamentos & \multicolumn{5}{c}{ CICLOS FERMENTATIVOS } \\
\cline { 2 - 6 }$(\mathrm{mg} \mathrm{Al} / \mathrm{L})$ & $1^{\circ}$ & $2^{\circ}$ & $3^{\circ}$ & $4^{\circ}$ & $5^{\circ}$ \\
\hline \hline Fle 0 & $4,05 \mathrm{Aa}$ & $3,23 \mathrm{Aa}$ & $2,942, \mathrm{Aa}$ & $3,05 \mathrm{Aa}$ & $3,10 \mathrm{Aa}$ \\
Fle 50 & $4,13 \mathrm{Aa}$ & $3,52 \mathrm{Ab}$ & $3,01 \mathrm{Aa}$ & $3,35 \mathrm{Aab}$ & $3,22 \mathrm{Aa}$ \\
Fle 100 & $4,09 \mathrm{Aa}$ & $3,40 \mathrm{Aab}$ & $3,04 \mathrm{Aa}$ & $3,35 \mathrm{Ab}$ & $3,14 \mathrm{Aa}$ \\
& \multicolumn{4}{c}{ COEFICIENTE DE VARIAÇÃO: 2,97} \\
\end{tabular}

As médias seguidas pelas mesmas letras (maiúsculas e minúsculas) não diferem entre si dentro de uma mesma coluna, de acordo com o teste de Tukey a 1 e $5 \%$ de significância. 
Tabela 9. Viabilidade (\%).

\begin{tabular}{cccccc}
\hline \hline Tratamentos & \multicolumn{5}{c}{ CICLOS FERMENTATIVOS } \\
\cline { 2 - 6 }$(\mathrm{mg} \mathrm{Al} / \mathrm{L})$ & $1^{\circ}$ & $2^{\circ}$ & $3^{\circ}$ & $4^{\circ}$ & $5^{\circ}$ \\
\hline \hline Fle 0 & $96 \mathrm{Aa}$ & $96 \mathrm{Aa}$ & $94 \mathrm{Aa}$ & $93 \mathrm{Aa}$ & $93 \mathrm{Aa}$ \\
Fle 50 & $97 \mathrm{Aa}$ & $96 \mathrm{Aa}$ & $94 \mathrm{Aa}$ & $93 \mathrm{Aa}$ & $94 \mathrm{Aa}$ \\
Fle 100 & $96 \mathrm{Aa}$ & $97 \mathrm{Aa}$ & $92 \mathrm{Aa}$ & $94 \mathrm{Aa}$ & $89 \mathrm{Bb}$ \\
\multicolumn{5}{c}{ COEFICIENTE DE VARIAÇÃO: 0,90 } \\
\hline \hline
\end{tabular}

As médias seguidas pelas mesmas letras (maiúsculas e minúsculas) não diferem entre si dentro de uma mesma coluna, de acordo com o teste de Tukey a 1 e $5 \%$ de significância.

Tabela 10. Teor inicial e final de trealose (\% MS) e glicogênio (\% MS).

\begin{tabular}{ccc}
\hline $\begin{array}{c}\text { Tratamentos } \\
(\mathrm{mg} \mathrm{Al} / \mathrm{L})\end{array}$ & $\begin{array}{c}\text { Trealose } \\
(\% \mathrm{MS})\end{array}$ & $\begin{array}{c}\text { Glicogênio } \\
(\% \mathrm{MS})\end{array}$ \\
\hline \hline Fle 0 & $3,28 \mathrm{Aa}$ & $9,19 \mathrm{Bb}$ \\
Fle 50 & $2,46 \mathrm{Bb}$ & $7,42 \mathrm{Aa}$ \\
Fle 100 & $2,37 \mathrm{Bb}$ & $6,62 \mathrm{Aa}$ \\
& COEFICIENTE DE VARIAÇÃO: 5,93 \\
\hline \hline
\end{tabular}

As médias seguidas pelas mesmas letras (maiúsculas e minúsculas) não diferem entre si dentro de uma mesma coluna, de acordo com o teste de Tukey a 1 e $5 \%$ de significância. 
Experimento 3

Tabela 11. Rendimento fermentativo (\%).

\begin{tabular}{cccccc}
\hline \hline Tratamentos & \multicolumn{5}{c}{ CICLOS FERMENTATIVOS } \\
\cline { 2 - 6 }$(\mathrm{mg} \mathrm{Al} / \mathrm{L})$ & $1^{\circ}$ & $2^{\circ}$ & $3^{\circ}$ & $4^{\circ}$ & $5^{\circ}$ \\
\hline \hline Fle 0 & $84,85 \mathrm{Aa}$ & $90,04 \mathrm{Aa}$ & $91,61 \mathrm{Aa}$ & $91,62 \mathrm{Aa}$ & $93,05 \mathrm{Aa}$ \\
Fle 50 & $83,61 \mathrm{Aa}$ & $90,54 \mathrm{Aa}$ & $92,45 \mathrm{Aa}$ & $92,27 \mathrm{Aa}$ & $92,41 \mathrm{Aa}$ \\
Fle 100 & $85,49 \mathrm{Aa}$ & $91,42 \mathrm{Aa}$ & $92,38 \mathrm{Aa}$ & $92,89 \mathrm{Aa}$ & $90,10 \mathrm{Aa}$ \\
\multicolumn{4}{c}{ COEFICIENTE DE VARIAÇÃO: 1,16} \\
\hline \hline
\end{tabular}

As médias seguidas pelas mesmas letras (maiúsculas e minúsculas) não diferem entre si dentro de uma mesma coluna, de acordo com o teste de Tukey a 1 e $5 \%$ de significância.

Tabela 12. Peso do fermento (g).

\begin{tabular}{cccccc}
\hline \hline Tratamentos & \multicolumn{5}{c}{ CICLOS FERMENTATIVOS } \\
\cline { 2 - 6 }$(\mathrm{mg} \mathrm{Al} / \mathrm{L})$ & $1^{\circ}$ & $2^{\circ}$ & $3^{\circ}$ & $4^{\circ}$ & $5^{\circ}$ \\
\hline \hline Fle 0 & $8,72 \mathrm{Aa}$ & $9,20 \mathrm{Aa}$ & $9,19 \mathrm{Aa}$ & $9,50 \mathrm{Aab}$ & $9,75 \mathrm{Aa}$ \\
Fle 50 & $8,91 \mathrm{Aa}$ & $9,28 \mathrm{Aa}$ & $9,26 \mathrm{Aa}$ & $9,48 \mathrm{Aa}$ & $9,75 \mathrm{Aa}$ \\
Fle 100 & $8,78 \mathrm{Aa}$ & $9,32 \mathrm{Aa}$ & $9,38 \mathrm{Aa}$ & $9,74 \mathrm{Ab}$ & $9,96 \mathrm{Aa}$ \\
\multicolumn{5}{c}{ COEFICIENTE DE VARIAÇÃO: 1,02} \\
\hline \hline
\end{tabular}

As médias seguidas pelas mesmas letras (maiúsculas e minúsculas) não diferem entre si dentro de uma mesma coluna, de acordo com o teste de Tukey a 1 e $5 \%$ de significância. 
Tabela 13. Glicerol (g/100 g ART).

\begin{tabular}{|c|c|c|c|c|c|}
\hline \multirow{2}{*}{$\begin{array}{c}\text { Tratamentos } \\
\text { (mg Al/L) }\end{array}$} & \multicolumn{5}{|c|}{ CICLOS FERMENTATIVOS } \\
\hline & $1^{\circ}$ & $2^{\circ}$ & $3^{\circ}$ & $4^{\circ}$ & $5^{\circ}$ \\
\hline Fle 0 & $3,82 A a$ & 3,59Aab & $3,59 \mathrm{Aa}$ & $3,23 \mathrm{Aa}$ & $3,27 \mathrm{Aa}$ \\
\hline Fle 50 & $4,03 \mathrm{Aa}$ & $3,75 \mathrm{Aa}$ & $3,44 \mathrm{Aa}$ & $3,21 \mathrm{Aa}$ & $3,27 \mathrm{Aa}$ \\
\hline Fle 100 & $4,07 \mathrm{Aa}$ & $3,41 \mathrm{Ab}$ & $3,22 \mathrm{Aa}$ & $3,26 \mathrm{Aa}$ & $3,22 \mathrm{Aa}$ \\
\hline \multicolumn{6}{|c|}{ COEFICIENTE DE VARIAÇÃO: 5,09} \\
\hline
\end{tabular}

As médias seguidas pelas mesmas letras (maiúsculas e minúsculas) não diferem entre si dentro de uma mesma coluna, de acordo com o teste de Tukey a 1 e $5 \%$ de significância.

Tabela 14. Viabilidade (\%).

\begin{tabular}{cccccc}
\hline \hline \multirow{2}{*}{$\begin{array}{c}\text { Tratamentos } \\
\text { (mg Al/L) })\end{array}$} & $1^{\circ}$ & $2^{\circ}$ & $3^{\circ}$ & $4^{\circ}$ & $5^{\circ}$ \\
\cline { 2 - 5 } Fle 0 & $99 \mathrm{Aa}$ & $96 \mathrm{Aab}$ & $96 \mathrm{Aa}$ & $94 \mathrm{Aa}$ & $91 \mathrm{Aa}$ \\
Fle 50 & $98 \mathrm{Aa}$ & $94 \mathrm{Aa}$ & $94 \mathrm{Aa}$ & $93 \mathrm{Aa}$ & $91 \mathrm{Aa}$ \\
Fle 100 & $98 \mathrm{Aa}$ & $97 \mathrm{Ab}$ & $95 \mathrm{Aa}$ & $92 \mathrm{Aa}$ & $90 \mathrm{Aa}$ \\
& \multicolumn{5}{c}{ COEFICIENTE DE VARIAÇÃO: 1,29} \\
\hline \hline
\end{tabular}

As médias seguidas pelas mesmas letras (maiúsculas e minúsculas) não diferem entre si dentro de uma mesma coluna, de acordo com o teste de Tukey a 1 e $5 \%$ de significância. 
Tabela 15. Teor inicial e final de trealose (\% MS) e glicogênio (\% MS).

\begin{tabular}{ccc}
\hline $\begin{array}{c}\text { Tratamentos } \\
(\mathrm{mg} \mathrm{Al} / \mathrm{L})\end{array}$ & $\begin{array}{c}\text { Trealose } \\
(\% \mathrm{MS})\end{array}$ & $\begin{array}{c}\text { Glicogênio } \\
(\% \mathrm{MS})\end{array}$ \\
\hline \hline Fle 0 & $3,21 \mathrm{Aa}$ & $8,56 \mathrm{Aa}$ \\
Fle 50 & $2,23 \mathrm{Bb}$ & $7,87 \mathrm{ABab}$ \\
Fle 100 & $2,29 \mathrm{Bb}$ & $6,36 \mathrm{Bb}$ \\
& COEFICIENTE DE VARIAÇÃO: 9,16 \\
\hline \hline
\end{tabular}

As médias seguidas pelas mesmas letras (maiúsculas e minúsculas) não diferem entre si dentro de uma mesma coluna, de acordo com o teste de Tukey a 1 e $5 \%$ de significância.

Experimento 4

Tabela 16. Rendimento fermentativo (\%).

\begin{tabular}{cccccc}
\hline \hline \multirow{2}{*}{$\begin{array}{c}\text { Tratamentos } \\
\text { (mg Al/L) }\end{array}$} & $1^{\circ}$ & $2^{\circ}$ & $3^{\circ}$ & $4^{\circ}$ & $5^{\circ}$ \\
\cline { 2 - 6 } Fle 0 & $86,7 \mathrm{Aa}$ & $87,3 \mathrm{Aab}$ & $88,1 \mathrm{ABCa}$ & $67,7 \mathrm{Aa}$ & $61,1 \mathrm{Aa}$ \\
Fle 100 & $88,5 \mathrm{Aa}$ & $84,7 \mathrm{Aa}$ & $80,4 \mathrm{Abab}$ & $53,4 \mathrm{Bb}$ & $55,1 \mathrm{Aa}$ \\
PE-2 0 & $84,5 \mathrm{Aa}$ & $90,0 \mathrm{Aab}$ & $89,9 \mathrm{ACac}$ & $89,3 \mathrm{CDc}$ & $90,7 \mathrm{BCb}$ \\
PE-2 100 & $86,3 \mathrm{Aa}$ & $92,1 \mathrm{Ab}$ & $91,6 \mathrm{Acac}$ & $90,0 \mathrm{Dd}$ & $90,2 \mathrm{Cc}$ \\
\multicolumn{5}{c}{ COEFICIENTE DE VARIAÇÃO: 2,80} \\
\hline \hline
\end{tabular}

As médias seguidas pelas mesmas letras (maiúsculas e minúsculas) não diferem entre si dentro de uma mesma coluna, de acordo com o teste de Tukey a 1 e $5 \%$ de significância. 
Tabela 17. Peso do fermento $(\mathrm{g})$.

\begin{tabular}{|c|c|c|c|c|c|}
\hline \multirow{2}{*}{$\begin{array}{c}\text { Tratamentos } \\
\text { (mg Al/L) }\end{array}$} & \multicolumn{5}{|c|}{ "CICLOS FERMENTATIVOS } \\
\hline & $1^{\circ}$ & $2^{\circ}$ & $3^{\circ}$ & $4^{\circ}$ & $5^{\circ}$ \\
\hline Fle 0 & 6,9Aa & 6,3Aa & $6,1 \mathrm{Aa}$ & $\overline{5,8 \mathrm{Aa}}$ & 6,5Aa \\
\hline Fle 100 & $7,0 \mathrm{Aa}$ & $6,0 \mathrm{Aa}$ & $5,8 \mathrm{Aa}$ & $5,8 \mathrm{Aa}$ & $6,6 \mathrm{Aa}$ \\
\hline PE-2 0 & $8,2 \mathrm{Bcbc}$ & $7,6 \mathrm{Bcbc}$ & $7,5 \mathrm{Bcbc}$ & $7,4 \mathrm{Bcbc}$ & $7,7 \mathrm{BCbc}$ \\
\hline PE-2 100 & $7,9 \mathrm{Cb}$ & $7,8 \mathrm{Cc}$ & $7,6 \mathrm{Cc}$ & $7,5 \mathrm{Cc}$ & 7,7Cc \\
\hline \multicolumn{6}{|c|}{ COEFICIENTE DE VARIAÇÃO: 3,63 } \\
\hline
\end{tabular}

Tabela 18. Glicerol (g/100 g ART).

\begin{tabular}{cccccc}
\hline \hline Tratamentos & \multicolumn{5}{c}{ CICLOS FERMENTATIVOS } \\
\cline { 2 - 6 }$(\mathrm{mg} \mathrm{Al} / \mathrm{L})$ & $1^{\circ}$ & $2^{\circ}$ & $3^{\circ}$ & $4^{\circ}$ & $5^{\circ}$ \\
\hline \hline Fle 0 & $3,5 \mathrm{Aa}$ & $3,1 \mathrm{Aa}$ & $3,5 \mathrm{Aa}$ & $3,9 \mathrm{Aa}$ & $3,9 \mathrm{Aa}$ \\
Fle 100 & $3,6 \mathrm{Bb}$ & $4,0 \mathrm{Bb}$ & $4,3 \mathrm{Bb}$ & $5,0 \mathrm{Bb}$ & $3,8 \mathrm{Bb}$ \\
PE-2 0 & $3,2 \mathrm{Cc}$ & $3,0 \mathrm{Cc}$ & $3,4 \mathrm{Cc}$ & $3,6 \mathrm{Cc}$ & $3,5 \mathrm{Cc}$ \\
PE-2 100 & 2,9Dd & 2,8Dd & 2,9Dd & $3,1 \mathrm{Dd}$ & $3,1 \mathrm{Dd}$ \\
\multicolumn{5}{c}{ COEFICIENTE DE VARIAÇÃO: 0,25 } \\
\hline \hline
\end{tabular}

As médias seguidas pelas mesmas letras (maiúsculas e minúsculas) não diferem entre si dentro de uma mesma coluna, de acordo com o teste de Tukey a 1 e $5 \%$ de significância. 
Tabela 19. Viabilidade (\%).

\begin{tabular}{cccccc}
\hline \hline Tratamentos & \multicolumn{5}{c}{ CICLOS FERMENTATIVOS } \\
\cline { 2 - 6 }$(\mathrm{mg} \mathrm{Al} / \mathrm{L})$ & $1^{\circ}$ & $2^{\circ}$ & $3^{\circ}$ & $4^{\circ}$ & $5^{\circ}$ \\
\hline \hline Fle 0 & $76 \mathrm{Aa}$ & $51 \mathrm{Aa}$ & $36 \mathrm{Aa}$ & $26 \mathrm{Aa}$ & $17 \mathrm{Aa}$ \\
Fle 100 & $76 \mathrm{Aa}$ & $49 \mathrm{Aa}$ & $29 \mathrm{Aa}$ & $17 \mathrm{Aa}$ & $12 \mathrm{Aa}$ \\
PE-2 0 & $85 \mathrm{Aab}$ & $78 \mathrm{BCbc}$ & $72 \mathrm{BCbc}$ & $64 \mathrm{BCbc}$ & $60 \mathrm{BCbc}$ \\
PE-2 100 & $90 \mathrm{Ab}$ & $78 \mathrm{Cc}$ & $68 \mathrm{Cc}$ & $60 \mathrm{Cc}$ & $59 \mathrm{Cc}$ \\
\multicolumn{5}{c}{ COEFICIENTE DE VARIAÇÃO: 7,81} \\
\hline \hline
\end{tabular}

As médias seguidas pelas mesmas letras (maiúsculas e minúsculas) não diferem entre si dentro de uma mesma coluna, de acordo com o teste de Tukey a 1 e $5 \%$ de significância.

Tabela 20. Teor inicial e final de trealose (\% MS) e glicogênio (\% MS).

\begin{tabular}{|c|c|c|}
\hline $\begin{array}{c}\text { Tratamentos } \\
\text { (mg Al/L) }\end{array}$ & $\begin{array}{c}\text { Trealose } \\
\text { (\% MS) }\end{array}$ & $\begin{array}{c}\text { Glicogênio } \\
\text { (\% MS) }\end{array}$ \\
\hline Fle 0 & $3,4 \mathrm{Cc}$ & 6,6Aa \\
\hline Fle 100 & $3,8 \mathrm{BCbc}$ & $5,0 \mathrm{Aa}$ \\
\hline PE-2 0 & 5,9ABab & $14,4 \mathrm{Bb}$ \\
\hline PE-2 100 & $6,1 \mathrm{Aa}$ & $12,7 \mathrm{Bb}$ \\
\hline \multicolumn{3}{|c|}{ COEFICIENTE DE VARIAÇÃO: 12,28 } \\
\hline
\end{tabular}




\section{REFERÊNCIAS BIBLIOGRÁFICAS}

ALVES, D.M.G. Fatores que afetam a formação de ácidos orgânicos bem como outros parâmetros da fermentação alcoólica. Piracicaba, 1993. 251p. Dissertação (Mestrado) - Escola Superior de Agricultura "Luiz de Queiroz", Universidade de São Paulo.

ALVES, D.M.G. Respostas fisiológicas de duas linhagens de Saccharomyces cerevisiae frente ao potássio durante a fermentação. Rio Claro, 2000. Tese (Doutorado) - Instituto de Biociências, Universidade Estadual Paulista.

AMORIM, H. V.; OLIVEIRA, A. J.;ZAGO, E. A.; BASSO, L. C.; GALLO, C. R. Processos de fermentação alcoólica: seu controle e monitoramento. Piracicaba, FERMENTEC, 1989. 145p.

ARIEFF, A.I. Aluminum and the pathogenesis of dialysis dementia. Environ Geochemistry Helth, v.12, n.2, p.89-93, 1990. 
BAKER, J.P.; SCHOFIELD, C.L. Aluminum toxicity to fish in acidic waters. Water Air Soil Pollut, v.18, n.5, p.289-309, 1982.

BASSO, L. C. Atenuação dos efeitos tóxicos do alumínio pelo tratamento térmico do mosto. Piracicaba: Reunião Anual Fermentec. FEALQ; ESALQ-USP, 1993. $101 \mathrm{p}$.

BASSO, L. C. Efeitos do alumínio no crescimento do fermento. Piracicaba: Reunião Anual Fermentec. FEALQ; ESALQ-USP, 1990. 56p.

BASSO, L.C. Efeitos tóxicos do alumínio na fermentação alcoólica. In: REUNIÃO BRASILEIRA DE FISIOLOGIA VEGETAL, 2., Piracicaba, 1989. Anais. Piracicaba: SBFV/ESALQ,1989. p.243.

BASSO, L. C. Efeitos tóxicos do alumínio na fermentação com fermento TA. Piracicaba: Reunião Anual Fermentec. FEALQ; ESALQ-USP, 1991. $105 p$.

BASSO, L.C.; AMORIM, H.V. Toxic action of aluminum toward yeast fermentation. / Euroconference, Sesimbra, 1997/.

BRIN, M. Transketolase: clinical aspects. Methods in Enzymology, v.9, n.7, p.506-514, 1966.

CHO, S.W.; JOSHI, J.G. Inactivation of bakers - yeast glucose - 6 -phosfhate dehydrogenase by aluminum. Biochemistry, v.28, n.8, p.3613-3618, Apr. 1989. 
$\mathrm{CHO}$, S.W.; KIM, G.Y. Activation of acid ribonuclease from bovine brain by aluminum. Journal of Biochemistry, v.110, n.5, p.802-805, Nov. 1991.

COSTA-CARVALHO, V.L.A.; MEIRELLES, D.S.; ROCHA-LEÃO, M.H.M. Production of glucose-grown glycogen-rich cells of Saccharomyces cerevisiae. Biotechnology Letters, v.8, n.1, p.57-62, 1986.

D'AMORE, T.; CRUMPLEM, R.; STEWART, G. G. The involvement of trahalose in yeast stress tolerance. Journal of Industrial Microbiology, v.7, n.3, p.191195, 1991.

DATE, R.A.; HOLLIDAY, J. Selecting Rhizobium for acid, infertile soils of the tropics. Nature, v.277, n.6, p.62-64, 1979.

EXLEY, C.; PRICE, N.C.; BIRCHALL, J.D. Aluminum inhibition of hexokinase activity in - vitro - A study in biological availability. Journal of Inorganic Biochemistry, v.54, n.4, p.297-304, June 1994.

FOY, C.D.; GERLOFF, G.C. Response of Chlorella pyrenoidosa to aluminum and low pH. Journal Phycology, v.8, n.2, p.268-271, 1972.

GUIDA, L.; SAIDI, Z.; HUGHES, M.N.; POOLE, R.K. Aluminum toxicity and binding to Escherichia coli. Archives of Microbiology, v.156, n.9, p.507-512, 1991.

GUTIERREZ, L. E. Ácidos orgânicos de caldo e folhas de cana-de-açúcar, In: REUNIÃO BRASILEIRA DE FISIOLOGIA VEGETAL, 2., Piracicaba,1989. Anais. Piracicaba:SBFV/ESALQ,1989. p.243. 
HOWELER, R. H., Identifying plants adaptable to low pH conditions. In: WRIGHT, R. J.; BALIGAR, V. C.; MURRMANN, R. P. (Ed.) Plant-soil interactions at low pH. Netherlands: Kluwer Academic, 1991. p.885-904.

HAUG. A. Molecular aspects of aluminum toxicity. Critical Reviews Plant Science, v.1, n.3, p.345-373, 1984.

HAUG, A.R.; VITORELLO, V. Cellular aspects of aluminum toxicity in plants. In: YAFUI, M.; STRONG, M.J.; OTA, K.; VERITY, M.A. Mineral and metal neurotoxicology. New York: CRC Press, 1997. cap.4, p.35-41.

HOUELAND, T. Aluminum and Alzheimer's disease: is there a causal connection? Environ Geochemistry Helth, v.12, n.1, p.173-178, 1990.

JONES, D.L.; KOCHIAN, L.V. Aluminum interaction with plasma membrane lipids and enzyme metal binding sites and its potential role in Al cytotoxicity. Febs Letters, v.400, n.1, p.51-57, Jan. 1997.

JONGBLOED, R.H.; BORSTPAUWELS, G.W.F.H. Effects of aluminum and pH on growth and potassium uptake by 3 ectomycorrhizal fungi in liquid culture. Plant and Soil, v.140, n.2, p.157-165, Feb. 1992.

KINRAIDE, T.B.; PARKER, D.R. Cation amelioration of aluminum toxicity in wheat. Plant Physiology, v.83, n.6, p.546-551, 1987.

KLIMASHEVSKY, E.L.; CHERNYSHEVA. Content of organic acids and physiologically active compounds in plants differing in their susceptibility to the toxicity of $\mathrm{Al}^{3 .}$ Plant Breeding Abstracts, v.50, n.2, p.7005, 1980. 
KOCHIAN, L.V. Cellular mechanisms of aluminum and resistance in plants. Annual Review Plant Physiology, v.46, n.9, p.237-260, 1995.

LILLIE, S. H. \& PRINGLE, J. R. Reserve carboydrate metabolism in Saccharomyces cerevisiae responses to nutrient limitation. The Journal of Bacteriology, Baltimore, 143: 1384-94p, 1980.

MACDIARMID, C.W.; GARDNER, R.C. Al toxicity in weast. Plant Physiology, v.112,p.1101-1109, 1996.

MACDIARMID, C.W.; GARDNER, R.C. Overexpression of the Saccharomyces cerevisiae magnesium transport system confers resistance to aluminum ion. Journal of Biological Chemistry, v.273, n.3, p.1727-1732, Jan. 1998.

MACDIARMID, C.W.; GARDNER, R.C. Saccharomyces cerevisiae as a genetic system for the study of aluminum toxicity in plants. In: CONFERENCE YEAST GENETICS MOLECULAR BIOLOGY, 17., Lisboa, 1995:.Abstracts. Lisboa, 1995. p.234-242.

MARTIN, R.B. Aluminum speciation in biology. IN: CHADWICK, D.J.; WHEALAN, J. (Ed.). Aluminum in Biology and Medicine. New York: John Wiley, 1992. p.5-25.

PRITCHARD, D.T. Spedtrophotometric determination of aluminum in soil extracts with xilenol orange. Analyst, v.92, n.5 p. 103-106, 1967. 
RAO, K.S.J.; EASWARAN, K.R.K. Al-27-NMR studies of aluminum transport across yeast cell membranes. Molecular and Cellular Biochemistry, v.175, n.1,2, p.59-63, Oct. 1997.

RYBAROVA, J. ; L. ADAMEK. Determination of maximum concentrations of aluminum and free chlorine in treated water to be used for making feed yeast. Kuasny Prom., v.21, n.6, p.126-29, 1975.

SARRUGE J. R. ; HAAG H. P. Análises químicas em plantas. Piracicaba: ESALQ/USP, 1974. 55p.

SCHOTT, E.J.; GARDNER, R.C. Aluminum: sensitive mutants of Saccharomyces cerevisiae. Molecular \& General Genetics, v.254, n.1, p.63-72, Mar. 1997.

SIMON, L.; KRIEGER, M.; SUNG, S.S. ; SMALLEY, T.J. Aluminum toxicity in tomato, Part 2: Leaf gas exchange, chlorophyl content and invertase activity. Journal of Plant Nutrition, v.17, n.3, p.307-317, 1994.

SUHAYDA, C.G. ; HAUG, A. Organic acid reduce aluminum toxicity in maize root membranes. Physiologia Plantarum, Copenhagen, v.68, n.1, p.189-195, 1986.

TREVELYAN, W.E. ; HARRISON, J.S. Studies on yeast metabolism. The trehalose content of baker's yeast during anaerobic fermentation. 5. Biochemical. Journal, v.62, n.4, p.177-183, 1956.

WHITE, J Yeast Technology. London: Chapman \& Hall, 1954. p. 286-293: Toxic action of common elements towards yeast growth. 
WOMACK, F.C.; COLOWICK, S.P. Proton - dependent inhibition of yeast and brain hexokinases by aluminum in ATP preparations. Proceedings of the National academy of Sciences of the United States of America, v.76, n.10, p.5080-5084, 1979.

YOSHINO, M.; YAMADA, Y.; MURAKAMI, K. Inhibition by aluminum ion of NAD dependent and NADP - dependent isocitrate dehydrogenases from yeast. International Journal of Biochemistry, v.24, n.10, p.1615-1618, Oct. 1992.

YOSHINO, M.; MURAKAMI, K.; KAWANO, K. Interaction of aluminum ion with ATP. Mechanism of the aluminum inhibition of glycerol kinase and its reversal by spermine. Biometals, v.11, n.1, p.63-67, Jan. 1998.

ZAGO, E.A.; AMORIM, H.V.; BASSO, L.C.; et al. Métodos analíticos para o controle da produção de álcool. Piracicaba: FERMENTEC/ESALQ-USP. 1989. $144 p$.

ZEL, J.; SVETEK, J.; CRNE, H. ; et al. Effects of aluminum on membrane fluidity of the mycorrhizal fungus Amanita muscaria. Physiology Plantarum, v.89, n.3, p.172-176, 1993. 